\title{
Hanford Waste Mineralogy Reference Report
}

\section{R.S. Disselkamp}

Washington River Protection Solutions LLC

Richland, WA 99352

U.S. Department of Energy Contract DE-AC27-08RV14800

$\begin{array}{lll}\text { EDT/ECN: } & \text { DRF } & \text { UC: None } \\ \text { Cost Center: } & 2 \mathrm{~GB} 00 & \text { Charge Code: } \\ \text { B\&R Code: } & \text { None } & \text { Total Pages: } 85\end{array}$

Key Words: Mineralogy, crystal phase, Hanford waste, tank summary, data review

Abstract: This report lists the observed mineral phases present in the Hanford tanks. This task was accomplished by performing a review of numerous reports that used experimental techniques including, but not limited to: $x$-ray diffraction,polarized light micoscopy, scanning electron microscopy, transmission electron microscopy, energy dispersive spectroscopy, electron energy loss spectroscopy, and particle size distribution analyses. This report contains tables that can be used as a quick reference to identify the crystal phases observed in Hanford waste.

TRADEMARK DISCLAIMER. Reference herein to any specific commercial product, process, or service by trade name, trademark, manufacturer, or otherwise, does not necessarily constitute or imply its endorsement, recommendation, or favoring by the United States Government or any agency thereof or its contractors or subcontractors.

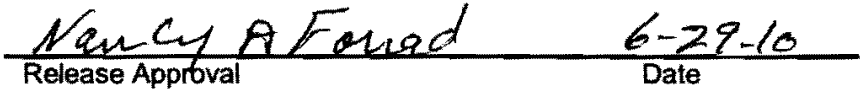

Approved For Public Release

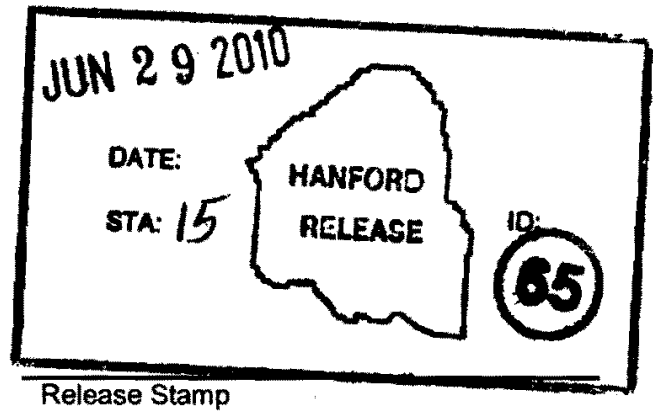




\begin{tabular}{|c|c|c|c|}
\hline \multicolumn{2}{|r|}{$\begin{array}{l}\text { Tank Operations Contractor (TOC) } \\
\text { RECORD OF REVISION }\end{array}$} & $\begin{array}{l}\text { (1) Document Number: } \\
\text { RPP-RPT-46618 }\end{array}$ & Page 1 \\
\hline \multicolumn{4}{|c|}{$\begin{array}{l}\text { (2) Title: } \\
\text { Hanford Waste Mineralogy Reference Report }\end{array}$} \\
\hline \multicolumn{4}{|c|}{ Change Control Record } \\
\hline \multirow{2}{*}{$\begin{array}{l}(3) \\
\text { Revision }\end{array}$} & \multirow{2}{*}{ (4) Description of Change - Replace, Add, and Delete Pages } & \multicolumn{2}{|c|}{ Authorized for Release } \\
\hline & & (5) Resp. Engr. (print/sign/date) & (6) Resp. Mgr. (print/sign/date) \\
\hline${ }^{1} \operatorname{Rs}$ & $\begin{array}{l}\text { Additional reports added in report and spelling errors } \\
\text { corrected in DRF and Title Page forms } \\
\text { DRF form - replace } \\
\text { Title page - replace } \\
\text { Table 1-1. (pg.25) table entry added } \\
\text { Table 1-1. (pgs.36,37,38) table entries added } \\
\text { REFERENCES (pg.79) - references added }\end{array}$ & R.S. Disselkamp & J.G. Reynolds \\
\hline
\end{tabular}




\section{Hanford Waste Mineralogy Reference Report}

Author

R.S. Disselkamp

Washington River Protection Solutions, LLC

Date Published

June 2010

Prepared for the U.S. Department of Energy

Assistant Secretary for Environmental Management

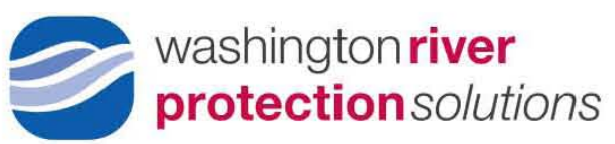

P.O. Box 850

Richland, Washington

Contractor for the U.S. Department of Energy

Office of River Protection under Contract DE-AC27-08RV14800 


\section{Table of Contents}

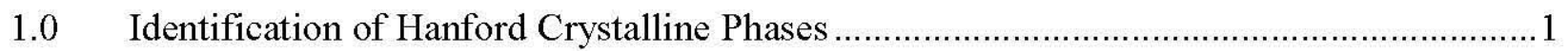

2.0 Group 1-8 Solid Sample Waste Type Mineralogy..........................................................6

3.0 Boil-down Solid Phase Identification in Hanford Tank Samples ......................................66

4.0 SEM-EDS Identification in Hanford Tank Samples.....................................................

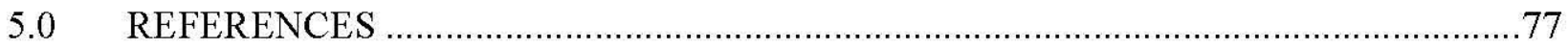

\section{List of Tables}

Table 1-1. Crystalline phases identified in Hanford tank waste samples. (56 pages) .................... 3

Table 2-1. A summary of Waste Treatment and Immobilization Plant Pacific Northwest National Laboratory (WTP-PNNL) studies involving Hanford actual waste

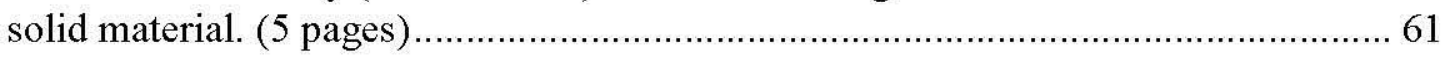

Table 3-1. The characteristics of Hanford tank boil-down laboratory studies. (4 pages)........... 67

Table 4-1. The elemental composition of various Hanford tank waste samples. (5 pages) ........ 72 


\section{LIST OF TERMS}

\section{Abbreviations and Acronyms}

BBI Best-Basis Inventory

EDS energy dispersive spectroscopy

EELS electron energy loss spectroscopy

PSD particle size distribution

PLM polarized light microscopy

PNNL Pacific Northwest National Laboratory

PUREX plutonium-uranium extraction

REDOX reduction-oxidation

SEM scanning electron microscopy

TEM transmission electron microscopy

TWINS tank waste inventory system

WTP Waste Treatment Plant

XRD $\quad x$-ray diffraction

\section{Units}

Vol.\% volume percent

Wt.\% weight percent (solid) 


\subsection{Identification of Hanford Crystalline Phases}

Successful operation of the Hanford cleanup operation involves, in part, an identification of the chemical speciation of solids in the Hanford waste. This is because both retrieval activities that depend on mixing and pumping processes, and waste treatment plant (WTP) leaching processes depend upon chemical speciation. Successful WTP leaching depends upon aluminum oxyhydroxide leaching by caustic at elevated temperature, and chromium oxyhydroxide leaching by the oxidizing agent permanganate at near ambient temperature, and requires solid phase identification for successful modeling of the processes. Leaching behavior is directly related to mineralogy type. Successful completion of these tasks includes compiling a readily searchable resource for solid waste. Key information includes mineralogy content for the Hanford tank farms, including detailed crystal and amorphous phases of all solid compounds present in the waste. This report summarizes all currently known mineralogical phases for solids contained within the Hanford tanks. This summary is presented as a "quick reference" source and additional information can be obtained from the referenced published reports. Mineralogical data herein is sorted by Hanford tank type. As new information becomes available, or as existing information is brought to our attention, this document will be revised.

Readers of this document are requested to contact the authors with suggestions of reports/data to be included in the future.

This report is organized into four sections. Each section presents different aspects of mineralogical phase identification in the Hanford tanks. The four sections include the following information:

- Section 1.0 Table 1-1. Crystal Phase Identification in Hanford Tanks.

- Section 2.0 Table 2-1. WTP-PNNL Group 1-8 Waste Characterization Results.

- Section 3.0 Table 3-1. Characterization of Mineral Identification in Boildown Laboratory Studies.

- Section 4.0 Table 4-1. Elemental Identification of Tank Solid Samples using SEM-EDS.

This report is a compilation of mineralogical data for the Hanford tank farm. Each table is sorted by tank and lists the following:

- mineral name;

- chemical formula or elements in solid sample;

- tank from which the analyzed sample was taken;

- experimental techniques used to analyze sample;

- waste type with unique pre-analysis processing; and 
- comments that include, at a minimum, the published report from which the data was taken.

This comprehensive list of mineralogical data can be used in efforts to:

a) examine chromium and aluminum leaching behavior;

b) correlate particle size distribution and density with mineralogy type;

c) examine solid-liquid equilibrium using reported solid characterization with supernate composition; and

d) correlate waste slurry data (e.g., rheology) to supernate and particle type.

Table 1-1 below presents the information above. 
Table 1-1. Crystalline phases identified in Hanford tank waste samples. (56 pages)

\begin{tabular}{|c|c|c|c|c|}
\hline $\begin{array}{l}\text { Sodium } \\
\text { carbonate } \\
\text { hydrate } \\
\text { (thermonatrite) }\end{array}$ & $\mathrm{Na}_{2} \mathrm{CO}_{3}-\mathrm{H}_{2} \mathrm{O}$ & AN-102 & $\begin{array}{l}\text { A2-saltcake waste type or caustic treated } \\
\text { supernate. }\end{array}$ & $\begin{array}{l}\text { From FH- } 0303343 \text {, and } 7 \mathrm{~S} 110-\text { WSC-05-011. Core } 307 \text {, Segments } \\
\text { 18, 19, 20, 21A, 21B. Identified using PLM and SEM-EDS. A } \\
\text { major component ( }(10 \text { wt. } \%) \text {. Particulates in interstitial liquid. } \\
\text { Origin of carbonate likely from breakdown of organics and } \\
\text { sequestration of carbon dioxide from atmosphere. } \\
\text { See also: 7S110-DLH-05-028. Identified crystalline solids were } \\
\text { characterized by XRD and SEM-EDS. This was a major component. } \\
\text { Obtained from caustic addition to supernate. This observation } \\
\text { suggests that the added caustic (i.e., sodium) may initiate } \\
\text { precipitation of } \mathrm{Na}_{2} \mathrm{CO}_{3} \text {. }\end{array}$ \\
\hline $\begin{array}{l}\text { Sodium } \\
\text { fluorophosphate } \\
\text { hydrate } \\
\text { (natrophosphate) }\end{array}$ & $\begin{array}{l}\mathrm{Na}_{7} \mathrm{~F}\left(\mathrm{PO}_{4}\right)_{2-} \\
19 \mathrm{H}_{2} \mathrm{O}\end{array}$ & AN-102 & $\begin{array}{l}\text { Supernate liquid used; liquid taken from } \\
\text { vicinity of A2 saltcake waste. }\end{array}$ & $\begin{array}{l}\text { From } 7 \mathrm{~S} 110-\mathrm{DLH}-05-028 \text {. Identified crystalline solids were } \\
\text { characterized by XRD and SEM-EDS. This was a minor } \\
\text { component. Obtained from caustic addition to supernate. This } \\
\text { observation suggests that the added caustic (i.e., sodium) may } \\
\text { initiate precipitation of sodium-containing } \mathrm{Na}_{7} \mathrm{~F}\left(\mathrm{PO}_{4}\right)_{2} \text {. }\end{array}$ \\
\hline $\begin{array}{l}\text { Sodium } \\
\text { oxalate } \\
\text { (natroxalate) }\end{array}$ & $\mathrm{Na}_{2} \mathrm{C}_{2} \mathrm{O}_{4}$ & AN-102 & A2-saltcake waste type. & $\begin{array}{l}\text { From FH-0303343, and 7S110-WSC-05-011. Core } 307 \text {, Segments } \\
18,19,20,21 \mathrm{~A}, 21 \mathrm{~B} \text {. Study undertaken as part of corrosion } \\
\text { mitigation work by caustic demand test. Tank contains PUREX } \\
\text { waste, } 52 \mathrm{kgal} 50 \text { wt. } \% \text { caustic added in } 2001 \text {. Identified using PLM } \\
\text { and SEM-EDS. A major component ( }>10 \mathrm{wt} . \% \text { ). This observation } \\
\text { suggests that the added caustic (i.e., sodium) may initiate } \\
\text { precipitation of sodium-containing sodium oxalate particulates } \\
\text { within interstitial liquid. }\end{array}$ \\
\hline
\end{tabular}


Table 1-1. Crystalline phases identified in Hanford tank waste samples. (56 pages)

\begin{tabular}{|c|c|c|c|c|}
\hline Mineral & $\begin{array}{l}\text { Chemical } \\
\text { Formula }\end{array}$ & Tank & Waste Type & Comments \\
\hline $\begin{array}{l}\text { Sodium } \\
\text { aluminum } \\
\text { carbonate } \\
\text { hydroxide } \\
\text { (dawsonite) }\end{array}$ & $\begin{array}{l}\mathrm{Na}_{2} \mathrm{Al}\left(\mathrm{CO}_{3}\right) \\
(\mathrm{OH})_{2}\end{array}$ & AN-102 & A2-saltcake waste type. & $\begin{array}{l}\text { From } 7 \mathrm{~S} 110 \text {-WSC-05-011. Core } 307 \text {, Segments } 18,19,20,21 \mathrm{~A} \text {, } \\
21 \mathrm{~B} \text {. Identified using PLM and SEM-EDS. A major component } \\
(>10 \mathrm{wt} . \% \text { ). } 52 \mathrm{kgal} 50 \mathrm{wt} \% \text { caustic added in } 2001 \text {. The high } \\
\text { caustic addition is significant as it can cause aid precipitation of } \\
\text { hydroxide solids. This observation suggests that the added caustic } \\
\text { (i.e., sodium) may initiate dissolution of sodium-containing sodium- } \\
\text { aluminum-carbonate. }\end{array}$ \\
\hline $\begin{array}{l}\text { Sodium } \\
\text { phosphate } \\
\text { hydrate }\end{array}$ & $\begin{array}{l}\mathrm{Na}_{3} \mathrm{PO}_{4^{-}} \\
12 \mathrm{H}_{2} \mathrm{O}\end{array}$ & AN-102 & A2-saltcake waste type. & $\begin{array}{l}\text { From 7S110-WSC-05-011. Core } 307 \text {, Segments } 18,19,20,21 \mathrm{~A} \text {, } \\
\text { 21B. Study undertaken as part of corrosion mitigation work by } \\
\text { caustic demand test. Tank contains PUREX waste, } 52 \mathrm{kgal} 50 \mathrm{wt} . \% \\
\text { caustic added in } 2001 \text {. Identified using PLM and SEM-EDS. A } \\
\text { minor component (1-10 wt.\%). This observation suggests that the } \\
\text { added caustic (i.e., sodium) initiates precipitation of sodium- } \\
\text { containing tri-phosphate. }\end{array}$ \\
\hline
\end{tabular}


Table 1-1. Crystalline phases identified in Hanford tank waste samples. (56 pages)

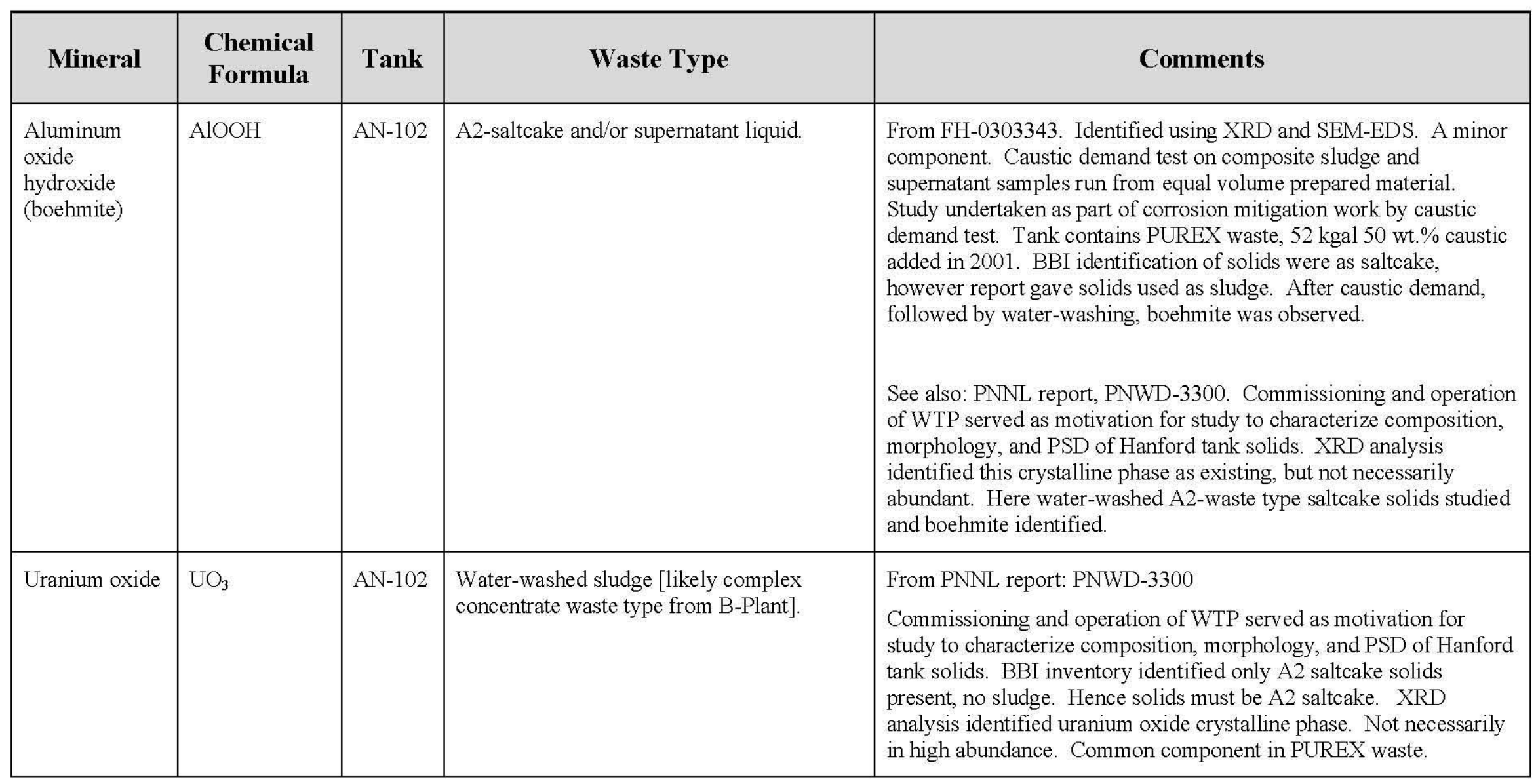


Table 1-1. Crystalline phases identified in Hanford tank waste samples. (56 pages)

\begin{tabular}{|c|c|c|c|c|}
\hline Mineral & $\begin{array}{l}\text { Chemical } \\
\text { Formula }\end{array}$ & Tank & Waste Type & Comments \\
\hline $\begin{array}{l}\text { Iron oxide } \\
\text { (hematite) }\end{array}$ & $\mathrm{Fe}_{2} \mathrm{O}_{3}$ & AN-102 & $\begin{array}{l}\text { Water-washed sludge [likely complex } \\
\text { concentrate waste type from PUREX]. }\end{array}$ & $\begin{array}{l}\text { From PNNL report: PNWD- } 3300 \\
\text { Commissioning and operation of WTP served as motivation for } \\
\text { study to characterize composition, morphology, and PSD of Hanford } \\
\text { tank solids. BBI inventory identified only A2 saltcake solids } \\
\text { present, no sludge. Hence solids must be A2 saltcake, with the iron } \\
\text { originating from PUREX waste stream. Although it seems odd to } \\
\text { have iron in a saltcake, the complexants in the waste could have had } \\
\text { an impact on presence of iron in waste. XRD analysis identified } \\
\text { hematite crystalline phase. Not necessarily in high abundance. }\end{array}$ \\
\hline $\begin{array}{l}\text { Calcium } \\
\text { carbonate } \\
\text { (calcite) }\end{array}$ & $\mathrm{CaCO}_{3}$ & AN-102 & $\begin{array}{l}\text { Water-washed sludge [likely complex } \\
\text { concentrate waste type from PUREX]. }\end{array}$ & $\begin{array}{l}\text { From PNNL report: PNWD-3300 } \\
\text { Commissioning and operation of WTP served as motivation for } \\
\text { study to characterize composition, morphology, and PSD of Hanford } \\
\text { tank solids. BBI inventory identified only A2 saltcake solids } \\
\text { present, no sludge. Hence solids must be A2 saltcake, with the iron } \\
\text { originating from PUREX waste stream. A combination of SEM, } \\
\text { EDS, XRD, and light scattering analysis techniques used to identify } \\
\text { calcite crystalline phase. Not in high abundance. }\end{array}$ \\
\hline Cerianite & $\mathrm{CeO}_{2}$ & AN-102 & $\begin{array}{l}\text { Water-washed sludge [likely complex } \\
\text { concentrate waste type from PUREX]. }\end{array}$ & $\begin{array}{l}\text { From PNNL report: PNWD-3300 } \\
\text { Commissioning and operation of WTP served as motivation for } \\
\text { study to characterize composition, morphology, and PSD of Hanford } \\
\text { tank solids. BBI inventory identified only A2 saltcake solids } \\
\text { present, no sludge. Hence solids must be A2 saltcake, with the iron } \\
\text { originating from PUREX waste stream. A combination of SEM, } \\
\text { EDS, XRD, and light scattering techniques used to identify cerianite } \\
\text { crystalline phase. Not in high abundance. }\end{array}$ \\
\hline
\end{tabular}


Table 1-1. Crystalline phases identified in Hanford tank waste samples. (56 pages)

\begin{tabular}{|c|c|c|c|c|}
\hline Mineral & $\begin{array}{l}\text { Chemical } \\
\text { Formula }\end{array}$ & Tank & Waste Type & Comments \\
\hline $\begin{array}{l}\text { Sodium nitrate } \\
\text { (nitratine) }\end{array}$ & $\mathrm{NaNO}_{3}$ & AN-102 & $\begin{array}{l}\text { Water-washed sludge [likely complex } \\
\text { concentrate waste type from PUREX]. }\end{array}$ & $\begin{array}{l}\text { From PNNL report: PNWD-3300 } \\
\text { Commissioning and operation of WTP served as motivation for } \\
\text { study to characterize composition, morphology, and PSD of Hanford } \\
\text { tank solids. BBI inventory identified only A2 saltcake solids } \\
\text { present, no sludge. Hence solids must be A2 saltcake, with the iron } \\
\text { originating from PUREX waste stream. A combination of SEM, } \\
\text { EDS, XRD, and light scattering analysis techniques used to identify } \\
\text { nitratine crystalline phase. In high abundance. }\end{array}$ \\
\hline Sodium nitrite & $\mathrm{NaNO}_{2}$ & AN-102 & $\begin{array}{l}\text { Water-washed sludge [likely complex } \\
\text { concentrate waste type from PUREX]. }\end{array}$ & $\begin{array}{l}\text { From PNNL report: PNWD-3300 } \\
\text { Commissioning and operation of WTP served as motivation for } \\
\text { study to characterize composition, morphology, and PSD of Hanford } \\
\text { tank solids. BBI inventory identified only A2 saltcake solids } \\
\text { present, no sludge. Hence solids must be A2 saltcake, with the iron } \\
\text { originating from PUREX waste stream. A combination of SEM, } \\
\text { EDS, XRD, and light scattering analysis techniques used to identify } \\
\text { sodium nitrite crystalline phase. In high abundance. }\end{array}$ \\
\hline $\begin{array}{l}\text { Sodium } \\
\text { oxalate } \\
\text { (natroxalate) }\end{array}$ & $\mathrm{Na}_{2} \mathrm{C}_{2} \mathrm{O}_{4}$ & AN-106 & NA sludge waste type. & $\begin{array}{l}\text { From Herting, } 2004 \text { ( } 7 \text { S110-DLH-04-013). Identified by Optical } \\
\text { Microscopy. Sludge produced from a neutralizing oxalic acid } \\
\text { solution used to dissolve a Heel in Tank C-106. The resulting added } \\
\text { caustic (i.e., sodium) likely precipitated (additional) sodium oxalate } \\
\text { used in corrosion mitigation. } \\
\text { From Warrant, } 2010 \text { (WRPS-1000562). C-solids included as part of } \\
\text { waste type. Identified by PLM, SEM, PSD, and EDS analyses. } \\
\text { Study conducted as part of caustic demand testing. Solids } \\
\text { precipitated during caustic addition. }\end{array}$ \\
\hline
\end{tabular}


Table 1-1. Crystalline phases identified in Hanford tank waste samples. (56 pages)

\begin{tabular}{|c|c|c|c|c|}
\hline Mineral & $\begin{array}{l}\text { Chemical } \\
\text { Formula }\end{array}$ & Tank & Waste Type & Comments \\
\hline $\begin{array}{l}\text { Aluminum } \\
\text { hydroxide } \\
\text { (gibbsite) }\end{array}$ & $\mathrm{Al}(\mathrm{OH})_{3}$ & AN-106 & NA sludge waste type. & $\begin{array}{l}\text { From Herting, } 2004 \text { ( } 7 \mathrm{~S} 110-\mathrm{DLH}-04-013 \text { ). Identified by Optical } \\
\text { Microscopy. Sludge produced from a neutralizing oxalic acid } \\
\text { solution used to dissolve a Heel in Tank C-106. Aluminum } \\
\text { originated from cladding in PUREX process waste. It is likely that } \\
\text { this process reduced gibbsite already present. }\end{array}$ \\
\hline $\begin{array}{l}\text { Sodium } \\
\text { fluorophosphate } \\
\text { hydrate } \\
\text { (natrophosphate) }\end{array}$ & $\begin{array}{l}\mathrm{Na}_{7} \mathrm{~F}\left(\mathrm{PO}_{4}\right)_{2} \bullet 19 \\
\mathrm{H}_{2} \mathrm{O}\end{array}$ & AN-106 & C sludge waste type. & $\begin{array}{l}\text { From Warrant, } 2010 \text { (WRPS-1000739, WRPS-1000562). C-solids } \\
\text { included as part of waste type. Identified by PLM, SEM, PSD, and } \\
\text { EDS analyses. Study conducted as part of caustic demand testing. } \\
\text { Solids precipitated during caustic addition. }\end{array}$ \\
\hline
\end{tabular}


Table 1-1. Crystalline phases identified in Hanford tank waste samples. (56 pages)

\begin{tabular}{|c|c|c|c|c|}
\hline Mineral & $\begin{array}{l}\text { Chemical } \\
\text { Formula }\end{array}$ & Tank & Waste Type & Comments \\
\hline Dawsonite & $\mathrm{NaAlCO}_{3}(\mathrm{OH})_{2}$ & AN-107 & A2-Saltcake solids analysis. & $\begin{array}{l}\text { From RPP-20018. Core } 304 \text { using segments } 18 \mathrm{R}, 19 \mathrm{R}, 20,21 \mathrm{~A} \text { and } \\
21 \mathrm{~B} \text { employed. Work performed to support corrosion mitigation by } \\
\text { examining caustic demand. Identification techniques include PLM, } \\
\text { SEM-EDS, and XRD. Dawsonite was the second most abundant } \\
\text { crystalline phase identified. PUREX cladding source of aluminum. } \\
\text { Very high carbonate concentration of } 0.066 \mathrm{~g}-\mathrm{CO}_{3} / \mathrm{g} \text {, observed from } \\
\text { waste inventory [BBI database]. Solids formed from caustic and } \\
\text { supernate addition to saltcake sample. }\end{array}$ \\
\hline $\begin{array}{l}\text { Sodium } \\
\text { fluoride } \\
\text { phosphate }\end{array}$ & $\begin{array}{l}\mathrm{Na}_{7} \mathrm{~F}\left(\mathrm{PO}_{4}\right)_{2-} \\
19 \mathrm{H}_{2} \mathrm{O}\end{array}$ & AN-107 & A2-Saltcake solids analysis. & $\begin{array}{l}\text { From RPP-20018. Core } 304 \text { using segments } 18 \mathrm{R}, 19 \mathrm{R}, 20,21 \mathrm{~A} \text { and } \\
21 \mathrm{~B} \text { employed. Work performed to support corrosion mitigation by } \\
\text { examining caustic demand. Identification techniques include PLM, } \\
\text { SEM-EDS, and XRD. Sodium fluoride phosphate was the fourth } \\
\text { most abundant crystalline phase identified. Waste template } \\
\text { inventory of phosphate is } 0.0047 \mathrm{~g}-\mathrm{PO}_{4} / \mathrm{g} \text { [BBI database]. } \\
\text { Performed by caustic and supernate addition to saltcake sample for } \\
\text { corrosion mitigation. }\end{array}$ \\
\hline
\end{tabular}


Table 1-1. Crystalline phases identified in Hanford tank waste samples. (56 pages)

\begin{tabular}{|c|c|c|c|c|}
\hline $\begin{array}{l}\text { Sodium nitrate } \\
\text { (nitratine) }\end{array}$ & $\mathrm{NaNO}_{3}$ & AN-107 & A2-Saltcake solids analysis. & $\begin{array}{l}\text { From RPP-20018. Core } 304 \text { using segments } 18 \mathrm{R}, 19 \mathrm{R}, 20,21 \mathrm{~A} \text { and } \\
21 \mathrm{~B} \text { employed. Work performed to support corrosion mitigation by } \\
\text { examining caustic demand. Identification techniques include PLM, } \\
\text { SEM-EDS, and XRD. Waste template and TWINS also showed } \\
\text { high nitrate concentration (ca. } 4.0 \mathrm{M} \text { ). Sodium nitrate was the sixth } \\
\text { most abundant crystalline phase identified. Performed by caustic } \\
\text { and supernate addition to saltcake sample. }\end{array}$ \\
\hline $\begin{array}{l}\text { Sodium } \\
\text { carbonate } \\
\text { hydrate }\end{array}$ & $\mathrm{Na}_{2} \mathrm{CO}_{3}-\mathrm{H}_{2} \mathrm{O}$ & AN-107 & $\begin{array}{l}\text { Supernate (that in contact with A2-saltcake } \\
\text { solids). }\end{array}$ & $\begin{array}{l}\text { From HNF-11585. Purpose of study was to measure physical and } \\
\text { chemical data for support of Hanford waste retrieval and } \\
\text { remediation. Use of polarized light microscopy (PLM), SEM-EDS, } \\
\text { and XRD was used to confirm crystal type. Very high carbonate } \\
\text { concentration of } 0.066 \mathrm{~g}-\mathrm{CO}_{3} / \mathrm{g} \text {, observed from waste inventory } \\
\text { [BBI database]. Precipitated supernate performed by a caustic } \\
\text { demand test. It is likely that the added caustic (i.e., sodium) } \\
\text { precipitated initially soluble } \mathrm{Na}_{2} \mathrm{CO}_{3} \text {. }\end{array}$ \\
\hline
\end{tabular}


Table 1-1. Crystalline phases identified in Hanford tank waste samples. (56 pages)

\begin{tabular}{|c|c|c|c|c|}
\hline Mineral & $\begin{array}{l}\text { Chemical } \\
\text { Formula }\end{array}$ & Tank & Waste Type & Comments \\
\hline $\begin{array}{l}\text { Thermonatrite, } \\
\text { Sodium } \\
\text { Carbonate } \\
\text { monohydrate }\end{array}$ & $\mathrm{Na}_{2} \mathrm{CO}_{3}-\mathrm{H}_{2} \mathrm{O}$ & AP-108 & NA saltcake waste type. & $\begin{array}{l}\text { From } 74 \mathrm{~A} 10-\mathrm{GAC}-08-164 \text {. Techniques used include PLM, SEM, } \\
\text { and XRD. Core } 330 \text { segments } 22,23,24 \mathrm{~A} \text {, and } 24 \mathrm{~B} \text { were used. } \\
\text { Sampling and solid phase identification supported both corrosion } \\
\text { mitigation and criticality safety programs. Both centrifuged solids } \\
\text { and settled solids were used. Grab sample analysis. This was the } \\
\text { major component found in the waste. A transfer in of } 1118 \mathrm{kgal} \text { of } \\
\mathrm{AP}-103 \text { waste yielded an increase of carbonate since this material } \\
\text { contained } 0.090 \mathrm{~g}-\mathrm{CO}_{3} / \mathrm{g} \text { carbonate [BBI database]. Grab sample } \\
\text { analysis. Sample was not treated prior to analysis (e.g., direct } \\
\text { analysis). }\end{array}$ \\
\hline $\begin{array}{l}\text { Sodium } \\
\text { Fluoride } \\
\text { Phosphate }\end{array}$ & $\begin{array}{l}\mathrm{Na}_{7} \mathrm{~F}\left(\mathrm{PO}_{4}\right)_{2}- \\
19 \mathrm{H}_{2} \mathrm{O}\end{array}$ & AP-108 & NA saltcake waste type. & $\begin{array}{l}\text { From 74A10-GAC-08-164. Techniques used include PLM, SEM, } \\
\text { and XRD. Core } 330 \text { segments } 22,23,24 \mathrm{~A} \text {, and } 24 \mathrm{~B} \text { were used. } \\
\text { Both centrifuged solids and settled solids were used. Grab sample } \\
\text { analysis. Minor components of both phosphate and fluoride } \\
(<0.01 \mathrm{M}) \text { [BBI database] were in the waste. Added caustic likely } \\
\text { precipitated the crystalline solid material. This was a minor } \\
\text { component found in the waste. Grab sample analysis. Sample was } \\
\text { not treated prior to analysis (e.g., direct analysis). }\end{array}$ \\
\hline $\begin{array}{l}\text { Kogarkoite, } \\
\text { sodium } \\
\text { fluoride } \\
\text { Sulfate }\end{array}$ & $\mathrm{Na}_{3} \mathrm{FSO}_{4}$ & AP-108 & NA saltcake waste type. & $\begin{array}{l}\text { From } 74 \mathrm{~A} 10-\mathrm{GAC}-08-164 \text {. Techniques used include PLM, SEM, } \\
\text { and XRD. Core } 330 \text { segments } 22,23,24 \mathrm{~A} \text {, and } 24 \mathrm{~B} \text { were used. } \\
\text { Both centrifuged solids and settled solids were used. Grab sample } \\
\text { analysis. Somewhat high sulfate, } 0.012 \mathrm{~g}-\mathrm{SO}_{4} / \mathrm{g} \text { observed [BBI } \\
\text { database], was contained in the waste per inventory report. This was } \\
\text { a minor component found in the waste. Grab sample analysis. } \\
\text { Sample was not treated prior to analysis (e.g., direct analysis). }\end{array}$ \\
\hline
\end{tabular}


Table 1-1. Crystalline phases identified in Hanford tank waste samples. (56 pages)

\begin{tabular}{|c|c|c|c|c|}
\hline Mineral & $\begin{array}{l}\text { Chemical } \\
\text { Formula }\end{array}$ & Tank & Waste Type & Comments \\
\hline $\begin{array}{l}\text { Sodium nitrate } \\
\text { (nitratine) }\end{array}$ & $\mathrm{NaNO}_{3}$ & $\begin{array}{l}\text { AW- } \\
101\end{array}$ & A2 saltcake. & $\begin{array}{l}\text { From HNF-13805. This report is a presentation to the American } \\
\text { Chemical Society, so details are omitted. There have been transfers } \\
\text { out of AW-101 (into AW-102 and AY-102), so perhaps this analysis } \\
\text { supports waste compatibility issues. Both simulant made sodium } \\
\text { nitrate solid particulates, and those obtained from tank AW-101 } \\
\text { direct sampling, have been compared. PLM analysis only. No } \\
\text { additional corroboration, say from SEM-EDS or XRD was given. }\end{array}$ \\
\hline Gibbsite & $\mathrm{Al}(\mathrm{OH})_{3}$ & $\begin{array}{l}\text { AW- } \\
105\end{array}$ & $\begin{array}{l}\text { Sludge solids. NCRW PUREX (aluminum } \\
\text { cladding) waste type. }\end{array}$ & $\begin{array}{l}\text { From PNNL-13394. Study undertaken to characterize solid phases } \\
\text { to understand better the caustic leaching (aka: enhanced sludge } \\
\text { washing (ESW)) and leaching of Hanford material, to support waste } \\
\text { treatment. Identified by TEM, SEM-EDS and XRD. Material was } \\
\text { examined after direct sampling. }\end{array}$ \\
\hline $\begin{array}{l}\text { Sodium nitrate } \\
\text { (nitratine) }\end{array}$ & $\mathrm{NaNO}_{3}$ & $\begin{array}{l}\text { AW- } \\
106\end{array}$ & A2 waste type saltcake. & $\begin{array}{l}\text { From } 7 \text { S110-GAC-08-150. Core } 323 \text {, segment } 10 \text {, solids. The } \\
\text { techniques of PLM, SEM-EDS and XRD were used to characterize } \\
\text { crystal type and abundance. Composition amount ca. } 30 \mathrm{wt} \% \% \text {. This } \\
\text { phase could have formed from precipitation of supernatant liquid, } \\
\text { but analyses were performed on the settled solids collected. }\end{array}$ \\
\hline $\begin{array}{l}\text { Sodium } \\
\text { carbonate } \\
\text { monohydrate }\end{array}$ & $\mathrm{Na}_{2} \mathrm{CO}_{3}-\mathrm{H}_{2} \mathrm{O}$ & $\begin{array}{l}\text { AW- } \\
106\end{array}$ & A2 waste type saltcake. & $\begin{array}{l}\text { From 7S110-GAC-08-150. Core } 323 \text {, segment } 10 \text {, solids. The } \\
\text { techniques of PLM, SEM-EDS and XRD were used to characterize } \\
\text { crystal type and abundance. Composition amount ca. } 10 \mathrm{wt} . \% \text {. This } \\
\text { phase could have formed from precipitation of supernatant liquid, } \\
\text { but analyses were performed on the settled solids collected. The } \\
\text { high concentration of carbonate of } 0.045 \mathrm{~g}-\mathrm{CO}_{3} / \mathrm{g} \text { [BBI database] is } \\
\text { the cause of precipitation of this solid crystal material. Purpose of } \\
\text { study unclear from reference above (or referenced documents } \\
\text { therein). From TWINS waste transfer documentation it is either in } \\
\text { support of waste compatibility (for transfer out) or an evaporator } \\
\text { campaign performed. }\end{array}$ \\
\hline
\end{tabular}


Table 1-1. Crystalline phases identified in Hanford tank waste samples. (56 pages)

\begin{tabular}{|c|c|c|c|c|}
\hline Mineral & $\begin{array}{l}\text { Chemical } \\
\text { Formula }\end{array}$ & Tank & Waste Type & Comments \\
\hline $\begin{array}{l}\text { Lithium } \\
\text { aluminum } \\
\text { hydroxide } \\
\text { hydrate }\end{array}$ & $\begin{array}{l}\mathrm{LiAl}_{2}(\mathrm{OH})_{7^{-}} \\
2 \mathrm{H}_{2} \mathrm{O}\end{array}$ & $\begin{array}{l}\text { AW- } \\
106\end{array}$ & A2 waste type saltcake. & $\begin{array}{l}\text { From 7S110-GAC-08-150. Core } 323 \text {, segment } 10 \text {, solids. This solid } \\
\text { is most likely due to contamination with } 0.3 \mathrm{M} \mathrm{LiBr} \text { hydrostatic fluid, } \\
\text { into the collected sample, used at the beginning of core sampling. } \\
\text { The aqueous lithium likely reacted with soluble aluminum and } \\
\text { hydroxide in the waste to form the observed solid. For LiBr use } \\
\text { use/sampling see LMHC-74B20-99-014 memo. The techniques of } \\
\text { PLM, SEM-EDS and XRD were used to characterize crystal type } \\
\text { and abundance. }\end{array}$ \\
\hline $\begin{array}{l}\text { Sodium } \\
\text { fluoride } \\
\text { phosphate }\end{array}$ & $\begin{array}{l}\mathrm{Na}_{7} \mathrm{~F}\left(\mathrm{PO}_{4}\right)_{2}- \\
19 \mathrm{H}_{2} \mathrm{O}\end{array}$ & AX-101 & $\begin{array}{l}\text { A composite sample from the tank was } \\
\text { cascade dissolved in water and a liquid plus } \\
\text { solids fraction obtained. The liquid fraction } \\
\text { was usually evaporated to yield precipitated } \\
\text { solids. In this particular experiment, the } \\
\text { supernatant liquid was cooled from } 50 \text { to } 20 \\
{ }^{\circ} \mathrm{C} \text {, yielding solids. No mention of existence } \\
\text { of solid phase in tank. Al saltcake }\end{array}$ & $\begin{array}{l}\text { From HNF-11585. The experimental techniques of polarized light } \\
\text { microscopy (PLM) and XRD were used to identify this phase in the } \\
\text { dissolved saltcake sample. PLM showed isotropic crystals. Both } \\
\text { phosphate and fluoride concentrations of waste [BBI database] were } \\
\text { very high at } 0.004 \mathrm{~g} / \mathrm{g} \text { and } 0.0008 \mathrm{~g} / \mathrm{g} \text {, respectively. }\end{array}$ \\
\hline
\end{tabular}


Table 1-1. Crystalline phases identified in Hanford tank waste samples. (56 pages)

\begin{tabular}{|c|c|c|c|c|}
\hline Dawsonite & $\mathrm{NaAlCO}_{3}(\mathrm{OH})_{2}$ & AY-101 & $\begin{array}{l}\text { NA-sludge studied, mixed with a } 50 / 50 \\
\text { vol. } \% \text { mixture of NA-sludge/supernate. }\end{array}$ & $\begin{array}{l}\text { From 7S110-RWW-08-147. This was a caustic demand test. } \\
\text { Crystalline phases were identified by PLM and XRD analyses. This } \\
\text { phase was most abundant in this report. Caustic demand of sludge } \\
\text { samples, in support of corrosion mitigation. The added caustic (i.e., } \\
\text { Na) with initially high carbonate present of } 0.098 \mathrm{~g} / \mathrm{g} \text { [BBI database] } \\
\text { yielded solids precipitation. }\end{array}$ \\
\hline $\begin{array}{l}\text { Iron oxide } \\
\text { (Hematite) }\end{array}$ & $\mathrm{Fe}_{2} \mathrm{O}_{3}$ & AY-101 & $\begin{array}{l}\text { NA-sludge studied, mixed with a 50/50 } \\
\text { vol. } \% \text { mixture of NA-sludge/supernate. }\end{array}$ & $\begin{array}{l}\text { From 7S110-RWW-08-147. This was a caustic demand test. } \\
\text { Crystalline phases were identified by PLM, XRD and SEM-EDS } \\
\text { analyses. This phase was the third most abundant solid phase in this } \\
\text { report. Caustic demand of sludge samples, in support of corrosion } \\
\text { mitigation. According to BBI and transfer records of TWINS, the } \\
\text { total iron concentration is appreciable at } 0.066 \mathrm{~g} / \mathrm{g} \text { sludge [BBI } \\
\text { database]. Therefore this level of iron present, or tank corrosion } \\
\text { release of iron, is responsible for hematite formation. In fact, caustic } \\
\text { added multiple times to mitigate corrosion issues. }\end{array}$ \\
\hline Thermonatrite & $\mathrm{Na}_{2} \mathrm{CO}_{3}-\mathrm{H}_{2} \mathrm{O}$ & AY-102 & $\begin{array}{l}\text { Although the solids are classified as } \\
\text { "sludge" [see Herting, FH- } 0303406 \text { ], they } \\
\text { could contain both solid waste types of BL- } \\
\text { solid and unspecified sludge. }\end{array}$ & $\begin{array}{l}\text { From 7S110-DLH-03-007. Sludge sample contained coring from } \\
\text { segments } 11,12,13 \text {, and 14A. PLM, SEM-EDS, and XRD were } \\
\text { utilized. Caustic demand test adding sodium plus high carbonate in } \\
\text { waste of } 0.066 \mathrm{~g} / \mathrm{g} \text { [BBI database] caused precipitation of crystal } \\
\text { phase. This observed crystal was a primary component. Sludge plus } \\
\text { supernatant mixture. }\end{array}$ \\
\hline
\end{tabular}


Table 1-1. Crystalline phases identified in Hanford tank waste samples. (56 pages)

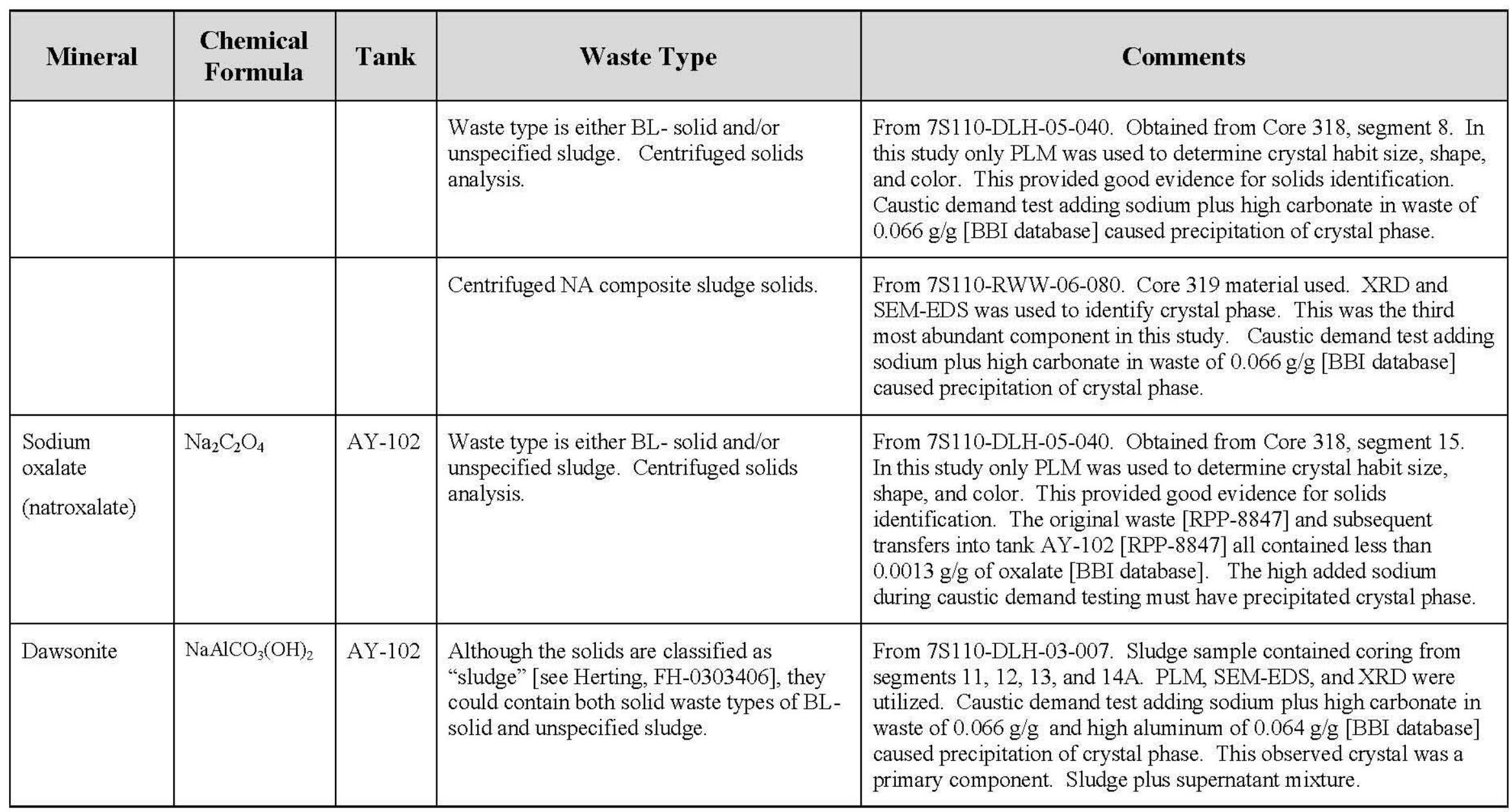


Table 1-1. Crystalline phases identified in Hanford tank waste samples. (56 pages)

\begin{tabular}{|c|c|c|c|c|}
\hline Mineral & $\begin{array}{l}\text { Chemical } \\
\text { Formula }\end{array}$ & Tank & Waste Type & Comments \\
\hline & & & Centrifuged NA composite sludge solids. & $\begin{array}{l}\text { From 7S110-RWW-06-080. Sample taken from Core } 319 \text {. XRD } \\
\text { and SEM-EDS was used to identify crystal phase. Caustic demand } \\
\text { test adding sodium plus high carbonate in waste of } 0.066 \mathrm{~g} / \mathrm{g} \text { and } \\
\text { high aluminum of } 0.064 \mathrm{~g} / \mathrm{g} \text { [BBI database] caused precipitation of } \\
\text { crystal phase. This was the fifth most abundant component in this } \\
\text { study. }\end{array}$ \\
\hline & & & $\begin{array}{l}\text { Leached (and water washed) NA-sludge } \\
\text { solids. }\end{array}$ & $\begin{array}{l}\text { From PNNL-14614. Cores } 270 \text { (segment 10) and } 281 \text { (segment 11) } \\
\text { were used. XRD and SEM-EDS techniques used to identify this } \\
\text { crystal phase as third most abundant. Residual caustic in waste and } \\
\text { high aluminum formed gibbsite. The dissolution of gibbsite requires } \\
\text { moderate temperature so solids persisted in these tests. } \\
\text { Approximately } 17 \text { wt. } \% \text { abundant. Un-leached and water leached } \\
\text { NA-sludge solids examined. Gibbsite remained after water leaching. }\end{array}$ \\
\hline
\end{tabular}


Table 1-1. Crystalline phases identified in Hanford tank waste samples. (56 pages)

\begin{tabular}{|c|c|c|c|c|}
\hline Mineral & $\begin{array}{l}\text { Chemical } \\
\text { Formula }\end{array}$ & Tank & Waste Type & Comments \\
\hline & & & $\begin{array}{l}\text { Composite NA-waste type sludge solids. } \\
\text { Direct sampling. }\end{array}$ & $\begin{array}{l}\text { From HNF-6047 Rev.0A. Cores } 270 \text { and } 273 \text {; whole core } \\
\text { composites. Identified using XRD, and acid } \\
\text { digestion/chromatography. Residual caustic in waste and high } \\
\text { aluminum formed gibbsite. The dissolution of gibbsite requires } \\
\text { moderate temperature so solids persisted in these tests. A major } \\
\text { component is solids, approximately } 30 \mathrm{wt} . \% \text {. }\end{array}$ \\
\hline
\end{tabular}


Table 1-1. Crystalline phases identified in Hanford tank waste samples. (56 pages)

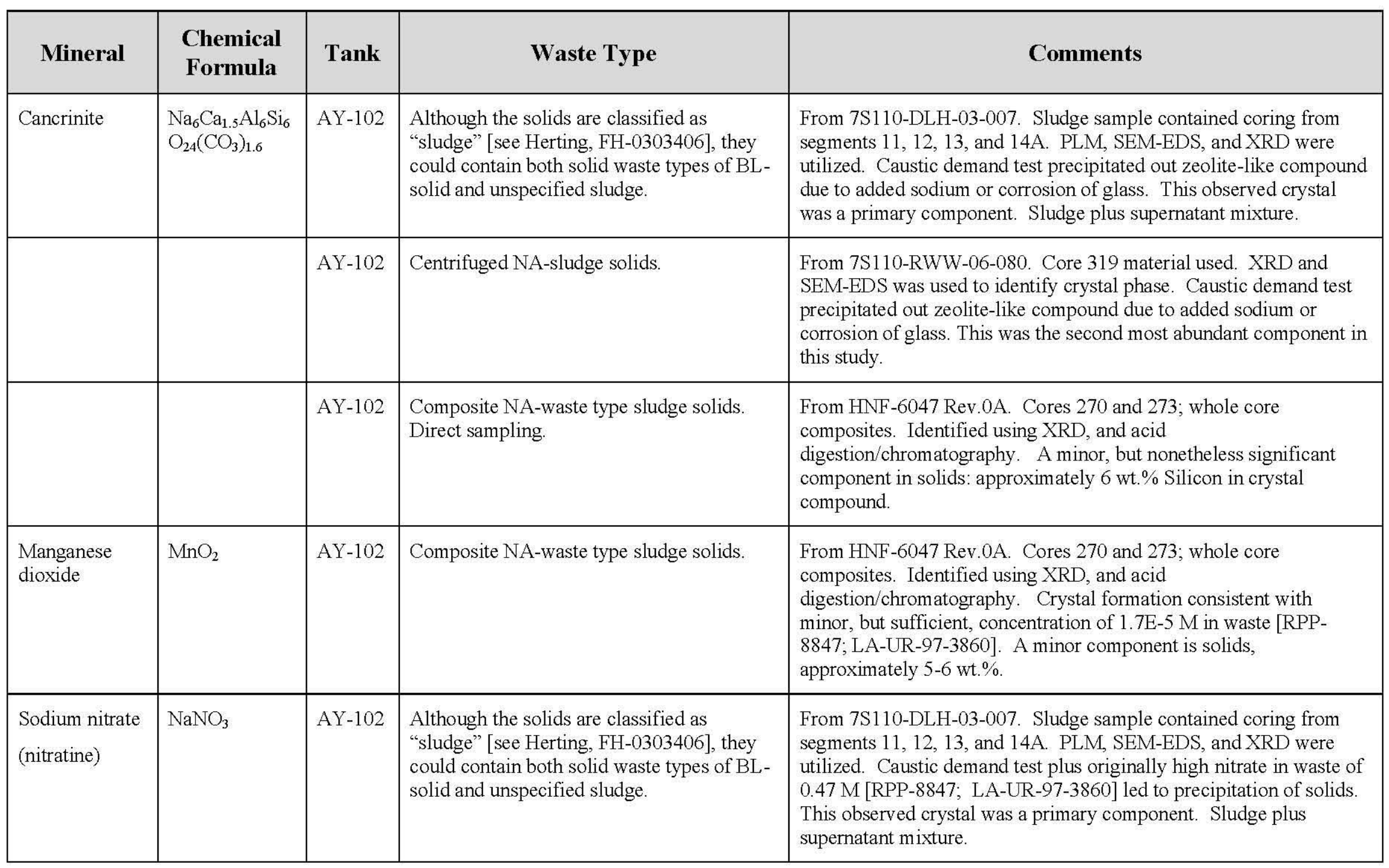


Table 1-1. Crystalline phases identified in Hanford tank waste samples. (56 pages)

\begin{tabular}{|c|c|c|c|c|}
\hline Mineral & $\begin{array}{l}\text { Chemical } \\
\text { Formula }\end{array}$ & Tank & Waste Type & Comments \\
\hline Boehmite & $\mathrm{Al}(\mathrm{O}) \mathrm{OH}$ & AZ-101 & $\begin{array}{l}\text { Water-washed P3AZ1 and/or NA sludge } \\
\text { solids. }\end{array}$ & $\begin{array}{l}\text { From PNNL report: PNWD-3300. BBI inventory identified P3AZ1 } \\
\text { and/or NA sludge as present. XRD analysis identified boehmite } \\
\text { crystalline phase as prevalent, but not necessarily in high abundance. } \\
\text { Broader XRD pattern than AN-102, suggesting less crystalline. } \\
\text { High aluminum in waste type of } 0.12 \mathrm{~g} / \mathrm{g} \text { consistent with boehmite } \\
\text { formation [BBI database]. }\end{array}$ \\
\hline Gibbsite & $\mathrm{Al}(\mathrm{OH})_{3}$ & AZ-101 & $\begin{array}{l}\text { Water-washed P3AZ1 and/or NA sludge } \\
\text { solids. }\end{array}$ & $\begin{array}{l}\text { From PNNL report: PNWD-3300. XRD analysis identified hematite } \\
\text { crystalline phase as prevalent. High aluminum in waste type of } 0.12 \\
\mathrm{~g} / \mathrm{g} \text { consistent with gibbsite formation [BBI database]. }\end{array}$ \\
\hline $\begin{array}{l}\text { Sodium nitrate } \\
\text { (nitratine) }\end{array}$ & $\mathrm{NaNO}_{3}$ & AZ-101 & $\begin{array}{l}\text { Water-washed P3AZ1 and/or NA sludge } \\
\text { solids. }\end{array}$ & $\begin{array}{l}\text { PNWD- } 3300 \text {. BBI inventory identified primarily A2 sludge solids } \\
\text { present. Hence solids must be A2 saltcake, with the iron originating } \\
\text { from PUREX waste stream. SEM, EDS, XRD, and light scattering } \\
\text { analysis identified nitratine crystalline phase. In high abundance. } \\
\text { Could have formed from inadvertent drying of sample. }\end{array}$ \\
\hline
\end{tabular}


Table 1-1. Crystalline phases identified in Hanford tank waste samples. (56 pages)

\begin{tabular}{|c|c|c|c|c|}
\hline Mineral & $\begin{array}{l}\text { Chemical } \\
\text { Formula }\end{array}$ & Tank & Waste Type & Comments \\
\hline Sodium nitrite & $\mathrm{NaNO}_{2}$ & AZ-101 & $\begin{array}{l}\text { Water-washed P3AZ1 and/or NA sludge } \\
\text { solids. }\end{array}$ & $\begin{array}{l}\text { PNWD-3300. BBI inventory identified primarily A2 sludge solids } \\
\text { present. The iron originating from PUREX waste stream. SEM, } \\
\text { EDS, XRD, and light scattering analysis identified sodium nitrite } \\
\text { crystalline phase. In high abundance. Could have formed from } \\
\text { inadvertent drying of sample. }\end{array}$ \\
\hline Sodium nitrite & $\mathrm{NaNO}_{2}$ & AZ-102 & $\begin{array}{l}\text { Composite sample from multiple cores ( } 261 \\
\& 262 \text { containing P3AZ2, PL2, SRR, } \\
\text { and/or NA sludge solids studied. P3AZ2 } \\
\text { and SRR waste types comprise } 71 \% \text { and } \\
25 \% \text {, respectively, of solids by mass. }\end{array}$ & $\begin{array}{l}\text { From PNNL WTP report: PNWD-3235 (WTP-RPT-054). XRD } \\
\text { analysis used to identify solid phases and compositions. The } \\
\text { nominal nitrite concentration of } 0.20 \mathrm{M} \text { is not a sufficient condition } \\
\text { for solids formation. Solids must have formed from dried sample. } \\
\text { Filtered supernatant was evaporated to } 50 \% \text { of initial volume at } 50 \\
\text { C, then cooled for solids precipitation, concentrating components } \\
\text { even further prior to precipitation. Third most abundant crystal } \\
\text { phase seen ( } 7 \mathrm{wt} . \% \text { ). }\end{array}$ \\
\hline
\end{tabular}


Table 1-1. Crystalline phases identified in Hanford tank waste samples. (56 pages)

\begin{tabular}{|c|c|c|c|c|}
\hline Mineral & $\begin{array}{l}\text { Chemical } \\
\text { Formula }\end{array}$ & Tank & Waste Type & Comments \\
\hline Goethite & $\mathrm{FeO}(\mathrm{OH})$ & AZ-102 & $\begin{array}{l}\text { P3AZ2, PL2, SRR, and/or NA sludge solids } \\
\text { studied. P } 3 \text { AZ2 and SRR waste types } \\
\text { comprise } 71 \% \text { and } 25 \% \text {, respectively, of } \\
\text { solids by mass. }\end{array}$ & $\begin{array}{l}\text { From 7S110-WSC-03-012. From Core } 310 \text {, segments } 18 \text { and } 19 \text {. } \\
\text { Identified from refractive index and PSD information. TWINS } \\
\text { indicates a solid iron amount of } 55 \mathrm{~g} / \mathrm{kg} \text { solids basis, supporting } \\
\text { identification of this phase. Only a tentative assignment can be } \\
\text { made from data. Estimated solids } 32 \text { mole } \% \text {. }\end{array}$ \\
\hline Gibbsite & $\mathrm{Al}(\mathrm{OH})_{3}$ & AZ-102 & $\begin{array}{l}\text { P3AZ2, PL2, SRR, and/or NA sludge solids } \\
\text { studied. P3AZ2 and SRR waste types } \\
\text { comprise } 71 \% \text { and } 25 \% \text {, respectively, of } \\
\text { solids by mass. }\end{array}$ & $\begin{array}{l}\text { From } 7 \mathrm{~S} 110-W S C-03-012 \text {. From Core } 310 \text {, segments } 18 \text { and } 19 \text {. } \\
\text { Identified from refractive index and PSD information. From BBI } \\
\text { database list aluminum at } 0.053 \mathrm{~g} / \mathrm{g} \text { concentration, supportive of } \\
\text { boehmite formation in this PUREX refluxing tank. Only a tentative } \\
\text { assignment can be made from data. Estimated solids } 16 \text { mole } \% \text {. }\end{array}$ \\
\hline $\begin{array}{l}\text { Aluminum } \\
\text { oxide } \\
\text { (Boehmite) }\end{array}$ & $\mathrm{AlO}(\mathrm{OH})$ & AZ-102 & $\begin{array}{l}\text { P3AZ2, PL2, SRR, and/or NA sludge solids } \\
\text { studied. P3AZ2 and SRR waste types } \\
\text { comprise } 71 \% \text { and } 25 \% \text {, respectively, of } \\
\text { solids by mass. }\end{array}$ & $\begin{array}{l}\text { From } 7 \mathrm{~S} 110-\mathrm{WSC}-03-012 \text {. From Core } 310 \text {, segments } 18 \text { and } 19 \text {. } \\
\text { Identified from refractive index and PSD information. From BBI } \\
\text { database list aluminum at } 0.053 \mathrm{~g} / \mathrm{g} \text { concentration, supportive of } \\
\text { boehmite formation in this PUREX refluxing tank. Only a tentative } \\
\text { assignment can be made from data. Estimated solids } 16 \text { mole } \% \text {. }\end{array}$ \\
\hline
\end{tabular}


Table 1-1. Crystalline phases identified in Hanford tank waste samples. (56 pages)

\begin{tabular}{|c|c|c|c|c|}
\hline Mineral & $\begin{array}{l}\text { Chemical } \\
\text { Formula }\end{array}$ & Tank & Waste Type & Comments \\
\hline Dawsonite & $\begin{array}{l}\mathrm{NaAl}\left(\mathrm{CO}_{3}\right) \\
(\mathrm{OH})_{2}\end{array}$ & AZ-102 & $\begin{array}{l}\text { P3AZ2, PL2, SRR, and/or NA sludge solids } \\
\text { studied. P3AZ2 and SRR waste types } \\
\text { comprise } 71 \% \text { and } 25 \% \text {, respectively, of } \\
\text { solids by mass. [However, cited report } \\
\text { states washed saltcake solids. From BBI, } \\
\text { no saltcake solids exist. ] } \\
\text { Settled solids suspended in a simulant } \\
\text { representative of supernate. PSD } \\
\text { distribution information with refractive } \\
\text { index data used to infer particle type. }\end{array}$ & $\begin{array}{l}\text { From 7S110-WSC-03-012. From Core } 310 \text {, segments } 18 \text { and } 19 . \\
\text { Identified from refractive index and PSD information. With } \\
\text { substantial aluminum, carbonate, and hydroxide, this crystal phase at } \\
\text { a low concentration is consistent with tank composition and history. } \\
\text { Only a tentative assignment can be made from data. Estimated } \\
\text { solids } 3 \text { mole } \% \text {. }\end{array}$ \\
\hline Gibbsite & $\mathrm{Al}(\mathrm{OH})_{3}$ & BX-101 & $\begin{array}{l}\text { Leached (and water washed) NA-sludge } \\
\text { solids. }\end{array}$ & $\begin{array}{l}\text { From PNNL-14614. Cores } 270 \text { (segment 10) and } 281 \text { (segment 11) } \\
\text { were used. XRD and SEM-EDS used to identify this major } \\
\text { abundant crystal phase. Purpose of testing was to characterize } \\
\text { material and assess water leachability of sludge. PUREX waste } \\
\text { following strontium recovery containing significant aluminum (ca. } \\
1.2 \mathrm{M} \text { ) [RPP-8847, LA-UR-97-3860]. Without caustic and mild } \\
\text { temperature gibbsite would not be expected to dissolve. Gibbsite } \\
\text { remained after washing of sludge. }\end{array}$ \\
\hline Cancrinite & $\begin{array}{l}\mathrm{Na}_{6} \mathrm{Ca}_{1.5} \mathrm{Al}_{6} \mathrm{Si}_{6} \\
\mathrm{O}_{24}\left(\mathrm{CO}_{3}\right)_{1.6}\end{array}$ & BX-101 & $\begin{array}{l}\text { Leached (and water washed) NA-sludge } \\
\text { solids. }\end{array}$ & $\begin{array}{l}\text { From PNNL-14614. Cores } 270 \text { (segment } 10 \text { ) and } 281 \text { (segment 11) } \\
\text { were used. XRD and SEM-EDS used to identify this major } \\
\text { abundant crystal phase. Purpose of testing was to characterize } \\
\text { material and assess water leachability of sludge. PUREX waste } \\
\text { following strontium recovery containing significant aluminum (ca. } \\
1.2 \mathrm{M} \text { ), calcium ( } 0.007 \mathrm{M} \text { ), and silicon ( } 0.026 \mathrm{M} \text { ) [RPP-8847; LA- } \\
\text { UR-97-3860]. Cancrinite remained after water washing. }\end{array}$ \\
\hline Gibbsite & $\mathrm{Al}(\mathrm{OH})_{3}$ & BX-103 & Sludge solids. Waste type CWP2. & $\begin{array}{l}\text { From PNNL-13394. Identified only through XRD, so amount not } \\
\text { quantified. }\end{array}$ \\
\hline
\end{tabular}


Table 1-1. Crystalline phases identified in Hanford tank waste samples. (56 pages)

\begin{tabular}{|c|c|c|c|c|}
\hline Mineral & $\begin{array}{l}\text { Chemical } \\
\text { Formula }\end{array}$ & Tank & Waste Type & Comments \\
\hline Gibbsite & $\mathrm{Al}(\mathrm{OH})_{3}$ & BX-105 & $\begin{array}{l}\text { Sludge solids. Waste types: BY ( } 39 \text { wt. \% } \\
\text { of solids) and CWP2 (39 wt. } \% \text { of solids). }\end{array}$ & $\begin{array}{l}\text { From PNNL-13394. Study undertaken to characterize solid phases } \\
\text { to understand better the enhanced sludge washing (ESW) and } \\
\text { leaching of Hanford material, to support waste treatment. Identified } \\
\text { only through XRD, so amount not quantified. Was observed in both } \\
3 \mathrm{M} \text { caustic leached and direct sampled material. This CW waste } \\
\text { contains sufficient aluminum for gibbsite to exist and since the direct } \\
\text { sampled material was not treated with caustic at moderate } \\
\text { temperature, it persisted in sample (i.e., did not dissolve). }\end{array}$ \\
\hline Gibbsite & $\mathrm{Al}(\mathrm{OH})_{3}$ & BX-107 & Sludge solids. Waste type: $1 \mathrm{C}$. & $\begin{array}{l}\text { From PNNL-13394. Identified by TEM, SEM-EDS, and XRD. Was } \\
\text { observed in direct sampled material. Aluminum content of bismuth- } \\
\text { phosphate waste of } 1 \mathrm{C} \text { solids is } 0.015 \mathrm{~g}-\mathrm{Al} / \mathrm{g} \text {-solids [BBI database]. }\end{array}$ \\
\hline $\begin{array}{l}\text { Aluminum } \\
\text { phosphate }\end{array}$ & $\mathrm{AlPO}_{4}$ & BX-107 & Sludge solids. Waste type: $1 \mathrm{C}$. & $\begin{array}{l}\text { From PNNL-13394. Study undertaken to characterize solid phases } \\
\text { to understand better the enhanced sludge washing (ESW) and } \\
\text { leaching of Hanford material, to support waste treatment. Identified } \\
\text { by TEM, SEM-EDS, and XRD. Was observed in direct sampled } \\
\text { material. Aluminum and phosphate content of bismuth-phosphate } \\
\text { waste of } 1 \mathrm{C} \text { solids is } 0.015 \mathrm{~g}-\mathrm{Al} / \mathrm{g} \text {-solids and } 0.069 \mathrm{~g}-\mathrm{PO} 4 / \mathrm{g} \text {-solids } \\
\text { [BBI database]. }\end{array}$ \\
\hline Aluminosilicate & Al-Si-O solids & BX-107 & Sludge solids. Waste type: $1 \mathrm{C}$. & $\begin{array}{l}\text { From PNNL-13394. Study undertaken to characterize solid phases } \\
\text { to understand better the enhanced sludge washing (ESW) and } \\
\text { leaching of Hanford material, to support waste treatment. Identified } \\
\text { by TEM, SEM-EDS, and XRD. Was observed in both caustic } \\
\text { leached ( } 3 \mathrm{M} \text { ) and direct sampled materials. The XRD analysis was } \\
\text { not analyzed to yield an exact composition (i.e., Al:Si ratio). } \\
\text { Aluminum and silicon content of bismuth-phosphate waste of } 1 \mathrm{C} \\
\text { solids is } 0.015 \mathrm{~g}-\mathrm{Al} / \mathrm{g} \text {-solids and } 0.006 \mathrm{~g} \text {-Si/g-solids [BBI database]. }\end{array}$ \\
\hline
\end{tabular}


Table 1-1. Crystalline phases identified in Hanford tank waste samples. (56 pages)

\begin{tabular}{|c|c|c|c|c|}
\hline Mineral & $\begin{array}{l}\text { Chemical } \\
\text { Formula }\end{array}$ & Tank & Waste Type & Comments \\
\hline Nordstrandite & $\mathrm{Al}(\mathrm{OH})_{3}$ & BX-109 & Sludge solids. Waste type: TBP. & $\begin{array}{l}\text { From PNNL-13394. Study undertaken to characterize solid phases } \\
\text { to understand better the enhanced sludge washing (ESW) and } \\
\text { leaching of Hanford material, to support waste treatment. Identified } \\
\text { only through XRD, so amount not quantified. Was observed in both } \\
\text { caustic leached ( } 3 \mathrm{M} \text { ) and direct sampled materials. Was observed in } \\
\text { both } 3 \mathrm{M} \text { caustic leached and direct sampled material. This CW } \\
\text { waste contains sufficient aluminum for nordstrandite to exist and } \\
\text { since the direct sampled material was not treated with caustic at } \\
\text { moderate temperature, it persisted in sample (i.e., did not dissolve). }\end{array}$ \\
\hline $\begin{array}{l}\text { Sodium } \\
\text { fluoride } \\
\text { phosphate }\end{array}$ & $\begin{array}{l}\mathrm{Na}_{7} \mathrm{~F}\left(\mathrm{PO}_{4}\right)_{2}- \\
19 \mathrm{H}_{2} \mathrm{O}\end{array}$ & BY-102 & $\begin{array}{l}\text { Found in dissolved BY-waste type saltcake } \\
\text { material. Composite core sample, see } \\
\text { Herting, HNF- } 8849 \text { Rev. } 0 \text {. The sample } \\
\text { from the tank was dissolved (using } \\
\text { sequential multi-step cascade dissolution } \\
\text { arrangement) in water and a liquid plus } \\
\text { solids fraction obtained. The liquid fraction } \\
\text { was evaporated to yield precipitated solids. } \\
\text { Hence solids dissolution and re- } \\
\text { precipitation were studied. }\end{array}$ & $\begin{array}{l}\text { From HNF-11585. Purpose of study was to measure physical and } \\
\text { chemical data for support of Hanford waste retrieval and } \\
\text { remediation. The reference used polarized light microscopy (PLM) } \\
\text { and XRD to identify this phase in the dissolved saltcake sample. } \\
\text { PLM showed isotropic crystals. This was an In-Tank Solidification } \\
\text { (ITS) tank that contained significant amount of both fluoride and } \\
\text { phosphate of } 0.022 \mathrm{~g} / \mathrm{g} \text { and } 0.025 \mathrm{~g} / \mathrm{g} \text {, respectively [BBI database], } \\
\text { consistent with the presence of this solid. } \\
\text { Also confirmed in: From HNF-5193. Waste type is BY saltcake. } \\
\text { Identified with PLM, XRD, and SEM. Composite sample obtained } \\
\text { from cores } 1-7 \text {. Found in grab saltcake solids sampling. Dissolution } \\
\text { tests performed with water. Residual solids, following dissolution, } \\
\text { were analyzed and identified listed solid. }\end{array}$ \\
\hline
\end{tabular}


Table 1-1. Crystalline phases identified in Hanford tank waste samples. (56 pages)

\begin{tabular}{|c|c|c|c|c|}
\hline Mineral & $\begin{array}{l}\text { Chemical } \\
\text { Formula }\end{array}$ & Tank & Waste Type & Comments \\
\hline \multirow[t]{2}{*}{$\begin{array}{l}\text { Sodium } \\
\text { fluoride sulfate }\end{array}$} & $\mathrm{Na}_{3} \mathrm{FSO}_{4}$ & BY-102 & BY-saltcake. & $\begin{array}{l}\text { From HNF-11585. Purpose of study was to measure physical and } \\
\text { chemical data for support of Hanford waste retrieval and } \\
\text { remediation. Direct sampling of solids. The reference used XRD } \\
\text { and PLM to identify solids in dissolved saltcake sample. This was } \\
\text { an In-Tank Solidification (ITS) tank that contained significant } \\
\text { amount of both fluoride and phosphate of } 0.022 \mathrm{~g} / \mathrm{g} \text { and } 0.025 \mathrm{~g} / \mathrm{g} \text {, } \\
\text { respectively [BBI database], consistent with the presence of this } \\
\text { solid. }\end{array}$ \\
\hline & & & & $\begin{array}{l}\text { From HNF-7031 Rev.0. Major phase identified from PLM and } \\
\text { SEM/EDS. Dissolution tests performed to simulate sluicing using in } \\
\text { habited water }(0.01 \mathrm{MNaOH}) \text {. }\end{array}$ \\
\hline Cancranite & $\begin{array}{l}\mathrm{Na}_{6} \mathrm{Ca}_{1.5} \mathrm{Al}_{6} \mathrm{Si}_{6} \\
\mathrm{O}_{24}\left(\mathrm{CO}_{3}\right)_{1.6}\end{array}$ & BY-102 & BY-saltcake. & $\begin{array}{l}\text { From HNF-5193 Rev.0. Major phase identified from PLM and } \\
\text { SEM/EDS. Dissolution tests performed using inhibited water to } \\
\text { dissolve material using simulated sluicing technique. }\end{array}$ \\
\hline Donathite & $\mathrm{Fe}(\mathrm{Fe}, \mathrm{Cr})_{2} \mathrm{O}_{4}$ & BY-104 & Sludge solids. PFeCN. & $\begin{array}{l}\text { From PNNL-13394. Study undertaken to characterize solid phases } \\
\text { to understand better the enhanced sludge washing (ESW) and } \\
\text { leaching of Hanford material, to support waste treatment. } \\
\text { Tentatively identified by TEM. Seen in direct sampled material. } \\
\text { The TBP waste was treated with potassium ferrocyanide as a cesium } \\
\text { scavenger, explaining the origin of this iron solid material. }\end{array}$ \\
\hline $\begin{array}{l}\text { Sodium } \\
\text { oxalate }\end{array}$ & $\mathrm{Na}_{2} \mathrm{C}_{2} \mathrm{O}_{4}$ & BY-106 & BY saltcake & $\begin{array}{l}\text { From HNF-7031 Rev.0. Major phase identified from PLM and } \\
\text { SEM/EDS. Dissolution tests performed to simulate sluicing using in } \\
\text { habited water }(0.01 \mathrm{MNaOH}) \text {. }\end{array}$ \\
\hline
\end{tabular}


Table 1-1. Crystalline phases identified in Hanford tank waste samples. (56 pages)

\begin{tabular}{|l|l|l|l|l|}
\hline \multicolumn{1}{|c|}{ Mineral } & $\begin{array}{l}\text { Chemical } \\
\text { Formula }\end{array}$ & Tank & \multicolumn{1}{|c|}{ Waste Type } & \multicolumn{1}{c|}{ Comments } \\
\hline $\begin{array}{l}\text { Sodium } \\
\text { fluoride } \\
\text { phosphate }\end{array}$ & $\begin{array}{l}\mathrm{Na}_{7} \mathrm{~F}_{2}\left(\mathrm{PO}_{4}\right)_{2}- \\
19 \mathrm{H}_{2} \mathrm{O}\end{array}$ & $\mathrm{BY}-109$ & $\begin{array}{l}\text { BY-saltcake waste type. The sample from } \\
\text { the tank was cascade-chain dissolution in } \\
\text { water and a liquid plus solids fraction } \\
\text { obtained. The liquid fraction was } \\
\text { evaporated to yield precipitated solids. }\end{array}$ & $\begin{array}{l}\text { From HNF-11585. Purpose of study was to measure physical and } \\
\text { chemical data for support of Hanford waste retrieval and } \\
\text { remediation. The sample was analyzed with polarized light } \\
\text { microscopy (PLM) and XRD to identify this phase in the saltcake } \\
\text { sample (e.g., BY9Evap2, BY9Evap4, BY9Evap5, BY9Evap6, and } \\
\text { BY9Dill). Identification based on comparison between standard } \\
\text { and waste samples. Found in saltcake-evaporated precipitated } \\
\text { liquid. This was an In-Tank Solidification (ITS) tank that contained } \\
\text { significant amount of both fluoride and phosphate of } 0.022 \text { g/g and } \\
\text { 0.025 g/g, respectively [BBI database], consistent with the presence } \\
\text { of this solid. }\end{array}$ \\
\hline $\begin{array}{l}\text { Sodium } \\
\text { fluoride } \\
\text { phosphate }\end{array}$ & $\begin{array}{l}\left.\mathrm{Na}-\mathrm{F}(\mathrm{PO})_{4}\right)_{2}- \\
19 \mathrm{H}_{2} \mathrm{O}\end{array}$ & BY-109 & $\begin{array}{l}\text { BY-saltcake waste type. The sample from } \\
\text { the tank was cascade dissolved in water and } \\
\text { a liquid plus solids fraction obtained. The } \\
\text { liquid fraction was evaporated to yield } \\
\text { precipitated solids. }\end{array}$ & $\begin{array}{l}\text { From HNF-8849. A mixture of cores 201 and 203. PLM used to } \\
\text { identify crystal phase. Standard sample analysis of solids collected } \\
\text { was employed. This was an In-Tank Solidification (ITS) tank that } \\
\text { contained significant amount of both fluoride and phosphate of } 0.022 \\
\text { g/g and } 0.025 \text { g/g, respectively [BBI database], consistent with the } \\
\text { presence of this solid. }\end{array}$ \\
\hline
\end{tabular}


Table 1-1. Crystalline phases identified in Hanford tank waste samples. (56 pages)

\begin{tabular}{|c|c|c|c|c|}
\hline Mineral & $\begin{array}{l}\text { Chemical } \\
\text { Formula }\end{array}$ & Tank & Waste Type & Comments \\
\hline $\begin{array}{l}\text { Sodium } \\
\text { fluoride sulfate }\end{array}$ & $\mathrm{Na}_{3} \mathrm{FSO}_{4}$ & BY-109 & BY-saltcake waste type [see HNF-8849]. & $\begin{array}{l}\text { From HNF-11585. Purpose of study was to measure physical and } \\
\text { chemical data for support of Hanford waste retrieval and } \\
\text { remediation. The reference used polarized light microscopy (PLM) } \\
\text { and SEM-EDS to identify this phase in the precipitated saltcake } \\
\text { liquid sample. PLM showed isotropic crystals. Identification based } \\
\text { on comparison between standard and a } 50-50 \text { (v/v) waste mix of BY- } \\
109 \text { and U-107 samples. Also seen in precipitated BY-109 } \\
\text { supernatant. Unclear if forming } 50-50 \text { mixture unambiguously } \\
\text { confirms phase presence, as well as precipitated BY-109 } \\
\text { supernatant. The sample from the tank was cascade-chain } \\
\text { dissolution in water and a liquid plus solids fraction obtained. The } \\
\text { liquid fraction was evaporated to yield precipitated solids. Found in } \\
\text { dissolved saltcake liquid, as studied here. This was an In-Tank } \\
\text { Solidification (ITS) tank that contained significant amount of both } \\
\text { fluoride and phosphate of } 0.022 \text { g/g and 0.025 g/g, respectively [BBI } \\
\text { database], consistent with the presence of this solid. } \\
\text { Also confirmed in: HNF-11744-VA. Techniques of PLM, SEM- } \\
\text { EDS, and XRD used to identify crystal phase. Identified in water- } \\
\text { washed saltcake solids. BY-waste type. } \\
\text { From HNF-11744-VA. Techniques of PLM, SEM-EDS, and XRD } \\
\text { used to identify crystal phase. Identified in water-washed saltcake } \\
\text { solids. This was an In-Tank Solidification (ITS) tank that contained } \\
\text { significant amount of both fluoride and phosphate of } 0.022 \mathrm{~g} / \mathrm{g} \text { and } \\
0.025 \mathrm{~g} / \mathrm{g} \text {, respectively [BBI database], consistent with the presence } \\
\text { of this solid. }\end{array}$ \\
\hline
\end{tabular}


Table 1-1. Crystalline phases identified in Hanford tank waste samples. (56 pages)

\begin{tabular}{|l|l|l|l|l|}
\hline Mineral & $\begin{array}{l}\text { Chemical } \\
\text { Formula }\end{array}$ & Tank & Waste Type & \multicolumn{1}{|c|}{ Comments } \\
\hline $\begin{array}{l}\text { Sodium } \\
\text { fluoride }\end{array}$ & NaF & BY-109 & $\begin{array}{l}\text { BY-saltcake waste type [see HNF-8849 } \\
\text { Rev.0]. }\end{array}$ & $\begin{array}{l}\text { From HNF-11585. Purpose of study was to measure physical and } \\
\text { chemical data for support of Hanford waste retrieval and } \\
\text { remediation. Usually forms double salts instead of NaF. However, } \\
\text { was confirmed to exist in BY-109 in one sample collected, as } \\
\text { determined by SEM and XRD. The sample from the tank was } \\
\text { cascade-chain dissolution in water and a liquid plus solids fraction } \\
\text { obtained. The liquid fraction was evaporated to yield precipitated } \\
\text { solids. Precipitated supernatant from dissolved saltcake studied } \\
\text { here. This was an In-Tank Solidification (ITS) tank that contained } \\
\text { significant amount of fluoride of 0.022 g/g [BBI database], } \\
\text { consistent with the presence of this solid formed from evaporated } \\
\text { liquid. } \\
\text { Also in HNF-11744-VA. Techniques of PLM, SEM-EDS, and XRD } \\
\text { used to identify crystal phase. Identified in water-washed saltcake } \\
\text { solids. This was an In-Tank Solidification (ITS) tank that contained } \\
\text { significant amount of fluoride of } 0.022 \mathrm{~g} / \mathrm{g} \text { [BBI database], } \\
\text { consistent with the presence of this solid formed from evaporated } \\
\text { liquid. }\end{array}$ \\
\hline
\end{tabular}


Table 1-1. Crystalline phases identified in Hanford tank waste samples. (56 pages)

\begin{tabular}{|l|l|l|l|l|}
\hline \multicolumn{1}{|c|}{ Mineral } & $\begin{array}{l}\text { Chemical } \\
\text { Formula }\end{array}$ & Tank & Waste Type & \multicolumn{1}{c|}{ Comments } \\
\hline $\begin{array}{l}\text { Sodium } \\
\text { oxalate } \\
\text { (natroxalate) }\end{array}$ & $\mathrm{Na}_{2} \mathrm{C}_{2} \mathrm{O}_{4}$ & BY-109 & BY-saltcake waste type. & $\begin{array}{l}\text { From HNF-11585. Purpose of study was to measure physical and } \\
\text { chemical data for support of Hanford waste retrieval and } \\
\text { remediation. This crystal is difficult to conclusively distinguish } \\
\text { from sodium carbonate using PLM and SEM-EDS. However, it has } \\
\text { a definitive XRD pattern that can be used to confirm its presence. } \\
\text { The sample from the tank was cascade dissolved in water and a } \\
\text { liquid plus solids fraction obtained. The liquid fraction was } \\
\text { evaporated to yield precipitated solids. Re-evaporated saltcake. } \\
\text { Confirmed by PLM, SEM-EDS, and XRD. According to BBI } \\
\text { Inventory, the oxalate solids concentration is } 0.0042 \text { mg/g solids } \\
\text { basis. }\end{array}$ \\
$\begin{array}{l}\text { Also confirmed in: From HNF-11744-VA. Techniques of PLM, } \\
\text { SEM-EDS, and XRD used to identify crystal phase. Identified in } \\
\text { water-washed saltcake solids. }\end{array}$ \\
$\begin{array}{l}\text { Also confirmed in: From 7S110-DLH-06-073. Both PLM (for } \\
\text { morphology) and SEM-EDS were used to identify crystal type. } \\
\text { Sodium is found primarily in sodium oxalate and sodium } \\
\text { aluminosilicate. Solids remaining after BY-waste type saltcake } \\
\text { dissolution in water. }\end{array}$
\end{tabular}


Table 1-1. Crystalline phases identified in Hanford tank waste samples. (56 pages)

\begin{tabular}{|c|c|c|c|c|}
\hline Mineral & $\begin{array}{l}\text { Chemical } \\
\text { Formula }\end{array}$ & Tank & Waste Type & Comments \\
\hline $\begin{array}{l}\text { Aluminum } \\
\text { hydroxide } \\
\text { (gibbsite } \\
\text { and/or } \\
\text { bayerite) }\end{array}$ & $\mathrm{Al}(\mathrm{OH})_{3}$ & BY-109 & BY-saltcake waste type. & $\begin{array}{l}\text { From HNF-11585. Purpose of study was to measure physical and } \\
\text { chemical data for support of Hanford waste retrieval and } \\
\text { remediation. The sample from the tank was cascade dissolved in } \\
\text { water and a liquid plus solids fraction obtained. The liquid fraction } \\
\text { was evaporated to yield precipitated solids. Evaporated supernatant } \\
\text { from dissolved liquid studied here. The compound } \mathrm{Al}(\mathrm{OH})_{3} \text { occurs } \\
\text { in several forms. Gibbsite, bayerite, and amorphous aluminum } \\
\text { hydroxide have been observed in Hanford tank wastes. In addition, } \\
\text { Norstrandite and doyleite are the names of two other possible } \\
\text { crystallographic forms of } \mathrm{Al}(\mathrm{OH})_{3} \text {. } \\
\text { Its crystals are generally too small to characterize by PLM, however } \\
\text { XRD provides a good analysis technique. Gibbsite and bayerite } \\
\text { identified by XRD. }\end{array}$ \\
\hline Cryolite & $\mathrm{Na}_{3} \mathrm{AlF}_{6}$ & BY-109 & $\begin{array}{l}\text { Formed from precipitation of evaporating } \\
\text { BY-109 dissolved saltcake waste type. }\end{array}$ & $\begin{array}{l}\text { From HNF-11585. Purpose of study was to measure physical and } \\
\text { chemical data for support of Hanford waste retrieval and } \\
\text { remediation. Evaporated supernatant from dissolved liquid studied } \\
\text { here. Composite sample. Observed for first time in this report. An } \\
\text { unusual crystal to form, it was identified by XRD and SEM-EDS. } \\
\text { This was an In-Tank Solidification (ITS) tank that contained } \\
\text { significant amount of both fluoride and aluminum of } 0.022 \mathrm{~g} / \mathrm{g} \text { and } \\
0.025 \mathrm{~g} / \mathrm{g} \text {, respectively [BBI database], consistent with the presence } \\
\text { of this solid. }\end{array}$ \\
\hline
\end{tabular}


Table 1-1. Crystalline phases identified in Hanford tank waste samples. (56 pages)

\begin{tabular}{|c|c|c|c|c|}
\hline Mineral & $\begin{array}{l}\text { Chemical } \\
\text { Formula }\end{array}$ & Tank & Waste Type & Comments \\
\hline $\begin{array}{l}\text { Sodium } \\
\text { diuranate }\end{array}$ & $\mathrm{Na}_{2} \mathrm{U}_{2} \mathrm{O}_{7}$ & BY-109 & $\begin{array}{l}\text { Evaporated supernatant from dissolved } \\
\text { liquid studied here. Composite sample. } \\
\text { Formed from precipitation of evaporating } \\
\text { BY-109 dissolved saltcake waste type. } \\
\text { Composite core sample, see Herting, HNF- } \\
8849 \text { Rev.0. }\end{array}$ & $\begin{array}{l}\text { From HNF-11585. Purpose of study was to measure physical and } \\
\text { chemical data for support of Hanford waste retrieval and } \\
\text { remediation. Not an unexpected phase. Identification confirmed } \\
\text { from SEM-EDS and slow-scan XRD of washed S- } 112 \text { residues. The } \\
\text { SEM images were taken of the "brightest" images. } \\
\text { Particulates in supernate residue. The BBI database U-total } \\
\text { concentration of } 0.49 \mathrm{mg} / \mathrm{g} \text { solids basis, considering little expected } \\
\text { in aqueous phase, is consistent with solid being present. }\end{array}$ \\
\hline $\begin{array}{l}\text { Sodium } \\
\text { aluminum } \\
\text { silicate }\end{array}$ & $\mathrm{Na}_{6} \mathrm{Al}_{2}\left(\mathrm{SiO}_{4}\right)_{3}$ & BY-109 & $\begin{array}{l}\text { Evaporated supernatant from dissolved } \\
\text { liquid studied here. Composite sample. } \\
\text { Formed from precipitation of evaporating } \\
\text { BY-109 dissolved saltcake waste type. } \\
\text { Composite core sample, see Herting, HNF- } \\
8849 \text { Rev.0. }\end{array}$ & $\begin{array}{l}\text { From HNF-11585. Purpose of study was to measure physical and } \\
\text { chemical data for support of Hanford waste retrieval and } \\
\text { remediation. The first of two a "novel" phases present is a sodium } \\
\text { aluminosilicate phase. Particles with this chemical } \\
\text { Compositions were identified by SEM/EDS in residue samples. } \\
\text { PLM also recognized this type of particle in BY9Orig. This } \\
\text { compound has not been identified by XRD. Phases such as zeolites } \\
\text { or cancrinite and sodalite are known to occur in Hanford tank } \\
\text { wastes, and would have chemistries and morphologies consistent } \\
\text { with this particulate. Particles suspended in supernatant (e.g., } \\
\text { residue particulates). This was an In-Tank Solidification (ITS) tank } \\
\text { that contained significant amount of both silicon and aluminum of } \\
0.0035 \mathrm{~g} / \mathrm{g} \text { and } 0.029 \mathrm{~g} / \mathrm{g} \text {, respectively [BBI database], consistent } \\
\text { with the presence of this solid. }\end{array}$ \\
\hline $\begin{array}{l}\text { Sodium } \\
\text { phosphate } \\
\text { hydrate }\end{array}$ & $\begin{array}{l}\mathrm{Na}_{3} \mathrm{PO}_{4-} \\
12 \mathrm{H}_{2} \mathrm{O}\end{array}$ & C-101 & $\begin{array}{l}\text { CWP1 ( } 62 \text { wt. } \% \text { by solids mass) and TBP } \\
\text { ( } 38 \text { wt. \% by solids mass) sludge composite } \\
\text { waste type. }\end{array}$ & $\begin{array}{l}\text { From 7S110-JMF-05-015. The techniques of PLM and SEM-EDS } \\
\text { were used to identify crystalline solid phases. A major constituent } \\
(>10 \mathrm{wt} \% \text { ). TBP waste type has significant phosphate and sodium } \\
\text { of } 0.025 \mathrm{~g} / \mathrm{g} \text { and } 0.27 \mathrm{~g} / \mathrm{g} \text {-solids, respectively [BBI database]. }\end{array}$ \\
\hline
\end{tabular}


Table 1-1. Crystalline phases identified in Hanford tank waste samples. (56 pages)

\begin{tabular}{|c|c|c|c|c|}
\hline Mineral & $\begin{array}{l}\text { Chemical } \\
\text { Formula }\end{array}$ & Tank & Waste Type & Comments \\
\hline Gibbsite & $\mathrm{Al}(\mathrm{OH})_{3}$ & $\mathrm{C}-101$ & CWP1, TBP sludge composite waste type. & $\begin{array}{l}\text { From 7S110-JMF-05-015. The techniques of PLM and SEM-EDS } \\
\text { were used to identify crystalline solid phases. A major constituent } \\
(>10 \mathrm{wt} \%) \text {. CWP1 waste type has significant aluminum of } 0.031 \\
\text { g/g-solids, however TBP waste does not }(0.0018 \mathrm{~g} / \mathrm{g} \text {-solids) [BBI } \\
\text { database]. }\end{array}$ \\
\hline \multirow{2}{*}{ Gibbsite } & & & & $\begin{array}{l}\text { From PNNL-16738. Purpose of report was to develop release } \\
\text { models for key contaminants in C-103 tank, including solids } \\
\text { characterization. Gibbsite was identified in the heel left over after } \\
\text { the sludge in C-103 was sluiced into AN-106. Thus, there is likely } \\
\text { gibbsite in the sludge in AN-106 as well. This mineral was } \\
\text { identified by XRD. Gibbsite accounted for more than } 90 \% \text { of the } \\
\text { minerals seen by SEM. This identification as consistent with the } \\
\text { gibbsite identification observed in bulk C- } 103 \text { sludge observed prior } \\
\text { to sluicing (See 7S110-DLH-04-015). CWP1 waste type has } \\
\text { significant aluminum of } 0.031 \mathrm{~g} / \mathrm{g} \text {-solids [BBI database]. }\end{array}$ \\
\hline & & & & $\begin{array}{l}\text { From } 7 \mathrm{~S} 110 \text {-DLH-04-015. The techniques of XRD and SEM-EDS } \\
\text { were used in solid crystalline phase identification. Both sample } \\
\text { types identified gibbsite with } 26.0 \mathrm{wt} \% \mathrm{Al} \text { for untreated sludge and } \\
18.9 \mathrm{wt} \% \mathrm{Al} \text { for centrifuged solids. Both untreated sludge and } \\
\text { centrifuged solids from sample } \mathrm{H} \text { studied. CWP1 waste type has } \\
\text { significant aluminum of } 0.031 \mathrm{~g} / \mathrm{g} \text {-solids [BBI database]. }\end{array}$ \\
\hline
\end{tabular}


Table 1-1. Crystalline phases identified in Hanford tank waste samples. (56 pages)

\begin{tabular}{|c|c|c|c|c|}
\hline Mineral & $\begin{array}{l}\text { Chemical } \\
\text { Formula }\end{array}$ & Tank & Waste Type & Comments \\
\hline $\begin{array}{l}\text { Iron oxide } \\
\text { (Hematite) }\end{array}$ & $\mathrm{Fe}_{2} \mathrm{O}_{3}$ & C-103 & CWP1 & $\begin{array}{l}\text { From 7S110-DLH-04-015. The techniques of XRD and SEM-EDS } \\
\text { were used in solid crystalline phase identification. Both sample } \\
\text { types identified hematite with } 58.6 \mathrm{wt} . \% \mathrm{Fe} \text { for untreated sludge and } \\
63.7 \mathrm{wt} . \% \mathrm{Fe} \text { for centrifuged solids. Both untreated sludge and } \\
\text { centrifuged solids from sample } \mathrm{H} \text { studied. CWP1 waste type has } \\
\text { significant } \mathrm{Fe} \text { of } 0.0072 \mathrm{~g} / \mathrm{g} \text {-solids [BBI database]. }\end{array}$ \\
\hline $\begin{array}{l}\text { Iron oxide } \\
\text { (Hematite) }\end{array}$ & $\mathrm{Fe}_{2} \mathrm{O}_{3}$ & C-106 & $\begin{array}{l}\text { Particulate residue from oxalic acid } \\
\text { dissolution of NA sludge waste type solids. }\end{array}$ & $\begin{array}{l}\text { From RPP-17158. Purpose of study was to assess the dissolution of } \\
\text { C-106 sludge solids in oxalic/nitric acids. Laboratory experiments. } \\
\text { This information could be used in heel dissolution predictions. XRD } \\
\text { and SEM-EDS analyses were used as diagnostic tools. The iron } \\
\text { concentration in tank possessed a concentration of } 0.00032 \mathrm{M} \text { in } \\
\text { aqueous phase [RPP-8847; LA-UR-96-3860]. Identified as major } \\
\text { component. }\end{array}$ \\
\hline $\begin{array}{l}\text { Aluminum } \\
\text { oxide } \\
\text { (Boehmite) }\end{array}$ & $\mathrm{AlOOH}$ & C-106 & $\begin{array}{l}\text { Particulate residue from oxalic acid } \\
\text { dissolution of NA sludge waste type solids. }\end{array}$ & $\begin{array}{l}\text { From RPP-17158. Purpose of study was to assess the dissolution of } \\
\text { C-106 sludge solids in oxalic/nitric acids. Laboratory experiments. } \\
\text { This information could be used in heel dissolution predictions. XRD } \\
\text { and SEM-EDS analyses were used as diagnostic tools. The } \\
\text { aluminum concentration in tank possessed a concentration of } 0.041 \\
\text { M in aqueous phase [RPP- } 8847 \text {; LA-UR-96-3860]. Spectra not } \\
\text { given. Identified as minor component. }\end{array}$ \\
\hline
\end{tabular}


Table 1-1. Crystalline phases identified in Hanford tank waste samples. (56 pages)

\begin{tabular}{|c|c|c|c|c|}
\hline $\begin{array}{l}\text { Silver (zero } \\
\text { valent) }\end{array}$ & $\mathrm{Ag}$ & C-106 & $\begin{array}{l}\text { Organic wash waste (OWW) PUREX waste } \\
\text { type. }\end{array}$ & $\begin{array}{l}\text { From PNNL-15372. Purpose of study was to study elemental and } \\
\text { speciation (oxidation state) of components in waste. XANES and } \\
\text { EXAFS techniques identified elemental zero-valent silver and not } \\
\text { AgI as predominant form of silver. This suggests that waste is in a } \\
\text { fairly reduced state. }\end{array}$ \\
\hline $\begin{array}{l}\text { Sodium } \\
\text { fluoride } \\
\text { phosphate }\end{array}$ & $\begin{array}{l}\mathrm{Na}_{7} \mathrm{~F}\left(\mathrm{PO}_{4}\right)_{2}- \\
12 \mathrm{H}_{2} \mathrm{O}\end{array}$ & C-107 & $\begin{array}{l}\text { 1C, CWP2, SRR sludge composite waste } \\
\text { type. }\end{array}$ & $\begin{array}{l}\text { From WRPS-0901014. Behavior seen during simulated (laboratory) } \\
\text { sluicing using supernate of core samples. Information used to assess } \\
\text { dissolution, during sluicing, of tank contents. The techniques of } \\
\text { SEM-EDS and PLM were used. Approximately } 35 \text { wt. } \% \text { observed } \\
\text { in residual. Cores } 68 \text { and } 69 \text {, and auger sample. The } 1 \mathrm{C} \text { waste type, } \\
\text { according to the BBI database, contains very high concentrations of } \\
\text { F }(0.010 \mathrm{~g}-\mathrm{F} / \mathrm{g}) \text { and PO4 }(0.069 \mathrm{~g}-\mathrm{PO} 4 / \mathrm{g}) \text {. Phosphate compounds } \\
\text { are generally soluble and will sluice well. }\end{array}$ \\
\hline Gibbsite & $\mathrm{Al}(\mathrm{OH})_{3}$ & C-107 & $\begin{array}{l}\text { 1C, CWP2, SRR sludge composite waste } \\
\text { type. }\end{array}$ & $\begin{array}{l}\text { From WRPS-0901014. Behavior seen during simulated (laboratory) } \\
\text { sluicing using supernate of core samples. Information used to assess } \\
\text { dissolution, during sluicing, of tank contents. Both gibbsite and } \\
\text { hematite solids were dissolved in } \mathrm{C}-107 \text { under these conditions. The } \\
\text { techniques of SEM-EDS and PLM were used. Between } 10-35 \mathrm{wt} . \% \\
\text { observed in original sample. Cores } 68 \text { and } 69 \text {, and auger sample. } \\
\text { The } 1 \mathrm{C} \text { waste type, according to the } \mathrm{BBI} \text { database, contains a very } \\
\text { high concentration of } \mathrm{Al}(0.015 \mathrm{~g}-\mathrm{Al} / \mathrm{g}) \text {. The simulated sluicing will } \\
\text { reduce hydroxide, enhancing gibbsite dissolution. }\end{array}$ \\
\hline
\end{tabular}


Table 1-1. Crystalline phases identified in Hanford tank waste samples. (56 pages)

\begin{tabular}{|c|c|c|c|c|}
\hline Mineral & $\begin{array}{l}\text { Chemical } \\
\text { Formula }\end{array}$ & Tank & Waste Type & Comments \\
\hline $\begin{array}{l}\text { Iron oxide } \\
\text { (Hematite) }\end{array}$ & $\mathrm{Fe}_{2} \mathrm{O}_{3}$ & C-107 & $\begin{array}{l}\text { 1C, CWP2, SRR sludge composite waste } \\
\text { type. }\end{array}$ & $\begin{array}{l}\text { From WRPS-0901014. Behavior seen during simulated sluicing of } \\
\text { core samples. Information used to assess dissolution, during } \\
\text { sluicing, of tank contents. Both gibbsite and hematite solids were } \\
\text { dissolved in C-107. The techniques of SEM-EDS and PLM were } \\
\text { used. Between } 10-25 \text { wt. } \% \text { observed in original sample. Cores } 68 \\
\text { and } 69 \text {, and auger sample, examined. The } 1 \mathrm{C} \text { waste type, according } \\
\text { to the BBI database, contains a very high concentration of Fe }(0.010 \\
\text { g-Fe/g). }\end{array}$ \\
\hline $\begin{array}{l}\text { Sodium } \\
\text { uranium } \\
\text { phosphate }\end{array}$ & $\begin{array}{l}\mathrm{Na}\left(\mathrm{UO}_{2}\right)\left(\mathrm{PO}_{4}\right) \\
2\end{array}$ & C-107 & $\begin{array}{l}\text { 1C, CWP2, SRR sludge composite waste } \\
\text { type. }\end{array}$ & $\begin{array}{l}\text { From WRPS-0901014. Behavior seen during simulated sluicing of } \\
\text { core samples. Information used to assess dissolution, during } \\
\text { sluicing, of tank contents. The techniques of SEM-EDS and PLM } \\
\text { were used. Between } 10-40 \mathrm{wt} . \% \text { observed in original sample. Cores } \\
68 \text { and } 69 \text {, and auger sample, examined. The } 1 \mathrm{C} \text { waste type, } \\
\text { according to the BBI database, contains a very high concentration of } \\
\text { U-total }(0.0019 \mathrm{~g}-\mathrm{U} / \mathrm{g}) \text { and PO4 }(0.069 \mathrm{~g}-\mathrm{PO} 4 / \mathrm{g}) \text {. }\end{array}$ \\
\hline
\end{tabular}


Table 1-1. Crystalline phases identified in Hanford tank waste samples. (56 pages)

\begin{tabular}{|c|c|c|c|c|}
\hline Mineral & $\begin{array}{l}\text { Chemical } \\
\text { Formula }\end{array}$ & Tank & Waste Type & Comments \\
\hline Sodium nitrite & $\mathrm{NaNO}_{2}$ & C-107 & $\begin{array}{l}\text { 1C, CWP2, SRR sludge composite waste } \\
\text { type. }\end{array}$ & $\begin{array}{l}\text { From WRPS- } 0901014 \text {. Behavior seen during simulated sluicing of } \\
\text { core samples. Information used to assess dissolution, during } \\
\text { sluicing, of tank contents. The techniques of SEM-EDS and PLM } \\
\text { were used. Approximately } 25 \mathrm{wt} . \% \text { observed in original sample. } \\
\text { Cores } 68 \text { and } 69 \text {, and auger sample. The } 1 \mathrm{C} \text { waste type, according to } \\
\text { the BBI database, contains a very high concentration of nitrite } \\
(0.0097 \mathrm{~g}-\mathrm{NO} 2 / \mathrm{g}) \text {. }\end{array}$ \\
\hline Gibbsite & $\mathrm{Al}(\mathrm{OH})_{3}$ & C-108 & $\begin{array}{l}\text { Waste types: TBP-F (primary) and } 1 \mathrm{C} \\
\text { (secondary). Sludge solids. }\end{array}$ & $\begin{array}{l}\text { From PNNL-13394. Study undertaken to characterize solid phases } \\
\text { to understand better the enhanced sludge washing (ESW) and } \\
\text { leaching of Hanford material, to support waste treatment. Identified } \\
\text { by XRD. Seen in both as-received and caustic leached }(3 \mathrm{M}) \text { solids. } \\
\text { The } 1 \mathrm{C} \text { waste type, according to the } \mathrm{BBI} \text { database, contains a very } \\
\text { high concentration of } \mathrm{Al}(0.015 \mathrm{~g}-\mathrm{Al} / \mathrm{g}) \text {. }\end{array}$ \\
\hline & & & & $\begin{array}{l}\text { From LAB-RPT-10-00001 Rev.0. Direct-sampled composite core } \\
\text { examined using PLM and SEM/EDS. This was a major phase } \\
\text { existing in tank waste. }\end{array}$ \\
\hline
\end{tabular}


Table 1-1. Crystalline phases identified in Hanford tank waste samples. (56 pages)

\begin{tabular}{|c|c|c|c|c|}
\hline Mineral & $\begin{array}{l}\text { Chemical } \\
\text { Formula }\end{array}$ & Tank & Waste Type & Comments \\
\hline \multirow[t]{2}{*}{ Gibbsite } & $\mathrm{Al}(\mathrm{OH})_{3}$ & C-108 & $\begin{array}{l}\text { Sludge composite auger sample, } \mathrm{Cl} \text { sludge } \\
\text { material. }\end{array}$ & $\begin{array}{l}\text { From WRPS-0901014. Behavior seen during simulated sluicing of } \\
\text { core samples. Information used to assess dissolution, during } \\
\text { sluicing, of tank contents. For } \mathrm{C}-108 \text {, the simulated sluicing } \\
\text { removed gibbsite and phosphates. The techniques of SEM-EDS and } \\
\text { PLM were used. Approximately } 15 \mathrm{wt} \% \text { observed in original } \\
\text { (auger) sample. The } 1 \mathrm{C} \text { waste type, according to the } \mathrm{BBI} \text { database, } \\
\text { contains a very high concentration of } \mathrm{Al}(0.015 \mathrm{~g}-\mathrm{Al} / \mathrm{g}) \text {. The } \\
\text { simulated sluicing will reduce hydroxide, enhancing dissolution. }\end{array}$ \\
\hline & & & & $\begin{array}{l}\text { From LAB-RPT-10-00001 Rev.0. Caustic-washed composite core } \\
\text { exam ined using SEM/EDS. This was a minor phase identified in the } \\
\text { tank waste. Amount not quantified. }\end{array}$ \\
\hline $\begin{array}{l}\text { Iron oxide } \\
\text { (Hematite) }\end{array}$ & $\mathrm{Fe}_{2} \mathrm{O}_{3}$ & C-108 & $\begin{array}{l}\text { Sludge composite auger sample, } \mathrm{Cl} \text { sludge } \\
\text { material. }\end{array}$ & $\begin{array}{l}\text { From WRPS-0901014. The technique of SEM-EDS was used. } \\
\text { Approximately } 5 \mathrm{wt} . \% \text { observed in original (auger) sample. The } 1 \mathrm{C} \\
\text { waste type, according to the BBI database, contains a very high } \\
\text { concentration of } \mathrm{Fe}(0.010 \mathrm{~g}-\mathrm{Fe} / \mathrm{g}) \text {. }\end{array}$ \\
\hline $\begin{array}{l}\text { Calcium } \\
\text { phosphate }\end{array}$ & $\begin{array}{l}\mathrm{Ca}_{3}\left(\mathrm{PO}_{4}\right)_{2-}^{-} \\
\mathrm{xH}_{2} \mathrm{O}\end{array}$ & C-108 & 1C Sludge solids. & $\begin{array}{l}\text { From LAB-RPT-10-00001 Rev.0. Caustic-washed composite core } \\
\text { exam ined using SEM/EDS. This was a minor phase identified in the } \\
\text { tank waste. Amount not quantified. }\end{array}$ \\
\hline
\end{tabular}


Table 1-1. Crystalline phases identified in Hanford tank waste samples. (56 pages)

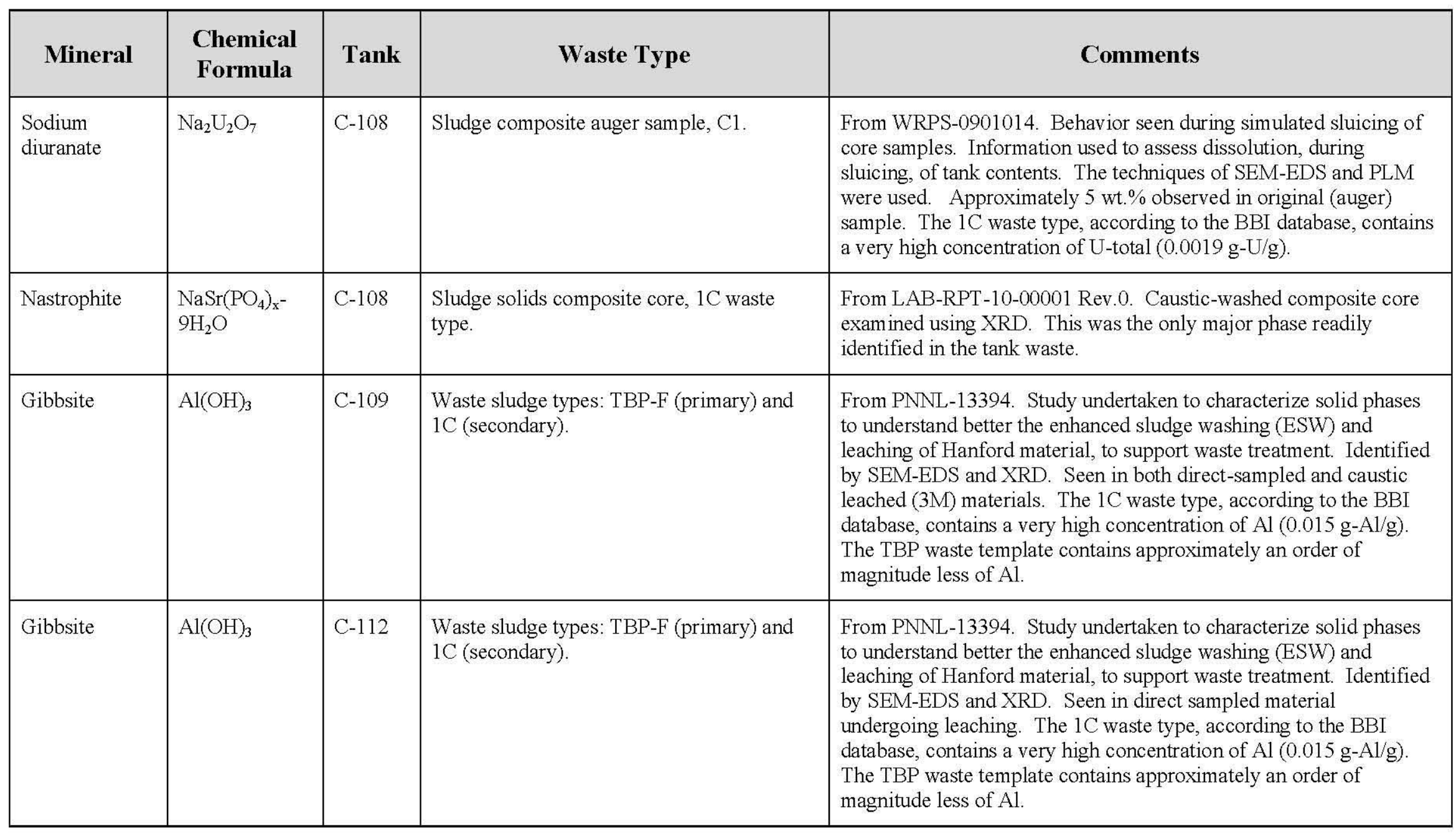


Table 1-1. Crystalline phases identified in Hanford tank waste samples. (56 pages)

\begin{tabular}{|c|c|c|c|c|}
\hline Mineral & $\begin{array}{l}\text { Chemical } \\
\text { Formula }\end{array}$ & Tank & Waste Type & Comments \\
\hline $\begin{array}{l}\text { Sodium } \\
\text { diuranate } \\
\text { and/or } \\
\text { clarkeite }\end{array}$ & $\begin{array}{l}\mathrm{Na}_{2} \mathrm{U}_{2} \mathrm{O}_{7} \\
\text { and/or } \\
\mathrm{Na}\left[\left(\mathrm{UO}_{2}\right) \mathrm{O}(\mathrm{O}\right. \\
\mathrm{H})] \text { hydrate }\end{array}$ & $\mathrm{C}-203$ & HS-waste type. & $\begin{array}{l}\text { From PNNL-14903. Purpose of study was to develop release } \\
\text { models for key contaminants remaining in sludge after closure of } \\
\text { tank C-203. This, in part, required identification of solid phases } \\
\text { present in heel material. Identified by XRD and SEM-EDS. Images } \\
\text { are of hexagonal acicular crystals. Water washed sludge solids. The } \\
\text { HS waste type contains significant U-total at } 0.041 \mathrm{~g}-\mathrm{U} / \mathrm{g} \text { [BBI } \\
\text { database]. } \\
\text { From PNNL-14903. Purpose of study was to develop release } \\
\text { models for key contaminants remaining in sludge after closure of } \\
\text { tank C-203. This, in part, required identification of solid phases } \\
\text { present in heel material. Identified by XRD and SEM-EDS. } \\
\text { Yellow nugget crystals. Water washed sludge solids. The HS waste } \\
\text { type contains significant U-total at } 0.041 \mathrm{~g}-\mathrm{U} / \mathrm{g} \text { and TOC of } 0.018 \mathrm{~g}- \\
\text { TOC/g [BBI database]. }\end{array}$ \\
\hline Goethite & $\mathrm{FeO}(\mathrm{OH})$ & C-203 & $\begin{array}{l}\text { Organic wash waste (OWW) PUREX waste } \\
\text { type. }\end{array}$ & $\begin{array}{l}\text { From PNNL-15372. Direct sampled solids analyzed. It was } \\
\text { observed from micro-XRD that this mineral type existed in solids } \\
\text { examined. Solid consistent with inventory of waste. }\end{array}$ \\
\hline Clarkeite & $\begin{array}{l}\mathrm{Na}\left[\left(\mathrm{UO}_{2}\right) \mathrm{O}(\mathrm{O}\right. \\
\mathrm{H})]\end{array}$ & C-203 & $\begin{array}{l}\text { Organic wash waste (OWW) PUREX waste } \\
\text { type. }\end{array}$ & $\begin{array}{l}\text { From PNNL-15372. Direct sampled solids analyzed. It was } \\
\text { observed from micro-XRD that this mineral type existed in solids } \\
\text { examined. Solid consistent with inventory of waste. }\end{array}$ \\
\hline
\end{tabular}


Table 1-1. Crystalline phases identified in Hanford tank waste samples. (56 pages)

\begin{tabular}{|c|c|c|c|c|}
\hline Mineral & $\begin{array}{l}\text { Chemical } \\
\text { Formula }\end{array}$ & Tank & Waste Type & Comments \\
\hline $\begin{array}{l}\text { Sodium } \\
\text { diuranate }\end{array}$ & $\mathrm{Na}_{2} \mathrm{U}_{2} \mathrm{O}_{7}$ & C-203 & $\begin{array}{l}\text { Organic wash waste (OWW) PUREX waste } \\
\text { type. }\end{array}$ & $\begin{array}{l}\text { From PNNL-15372. Direct sampled solids analyzed. It was } \\
\text { observed from micro-XRD that this mineral type existed in solids } \\
\text { examined. Solid consistent with inventory of waste. }\end{array}$ \\
\hline Cejkaite & $\begin{array}{l}\text { Na-Al-P-O } \\
\text { containing } \\
\text { crystals }\end{array}$ & C-204 & HS-waste type. & $\begin{array}{l}\text { From PNNL-14903. Purpose of study was to develop release } \\
\text { models for key contaminants remaining in sludge after closure of } \\
\text { tank C-203. This, in part, required identification of solid phases } \\
\text { present in heel material. Identified by XRD and SEM-EDS. Yellow } \\
\text { nugget crystals. Water washed sludge solids. The HS waste type, } \\
\text { according to the BBI database, did not give neither phosphate nor } \\
\text { aluminum concentrations of solids. No justification for the presence } \\
\text { of this solid can be given. }\end{array}$ \\
\hline $\begin{array}{l}\text { Sodium } \\
\text { uranate and/or } \\
\text { clarkeite }\end{array}$ & $\begin{array}{l}\mathrm{Na}_{2} \mathrm{U}_{2} \mathrm{O}_{7} \\
\text { and/or } \\
\mathrm{Na}\left[\left(\mathrm{UO}_{2}\right) \mathrm{O}(\mathrm{O}\right. \\
\mathrm{H})] \text { hydrate }\end{array}$ & C-204 & HS-waste type. & $\begin{array}{l}\text { From PNNL-14903. Purpose of study was to develop release } \\
\text { models for key contaminants remaining in sludge after closure of } \\
\text { tank C-203. This, in part, required identification of solid phases } \\
\text { present in heel material. Identified by XRD and SEM-EDS. Images } \\
\text { are of hexagonal acicular crystals. Water washed sludge solids. The } \\
\text { HS waste type contains significant U-total at } 0.041 \mathrm{~g}-\mathrm{U} / \mathrm{g} \text { [BBI } \\
\text { database]. }\end{array}$ \\
\hline $\begin{array}{l}\text { Iron- } \\
\text { chromium- } \\
\text { nickel crystals }\end{array}$ & $\begin{array}{l}\text { Fe-Cr-Ni-O-C } \\
\text { crystals }\end{array}$ & C-204 & HS-waste type. & $\begin{array}{l}\text { From PNNL-14903. Purpose of study was to develop release } \\
\text { models for key contaminants remaining in sludge after closure of } \\
\text { tank C-203. This, in part, required identification of solid phases } \\
\text { present in heel material. Identified by XRD and SEM-EDS. Images } \\
\text { are of hexagonal angular acicular crystals. Water washed sludge } \\
\text { solids. The HS waste type contains significant: Fe at } 0.080 \mathrm{~g}-\mathrm{Fe} / \mathrm{g} \text {; } \\
\mathrm{Cr} \text { at } 0.0015 \mathrm{~g}-\mathrm{Cr} / \mathrm{g} \text {; and Ni at } 0.00017 \mathrm{~g}-\mathrm{Ni} / \mathrm{g} \text { [BBI database]. }\end{array}$ \\
\hline
\end{tabular}


Table 1-1. Crystalline phases identified in Hanford tank waste samples. (56 pages)

\begin{tabular}{|c|c|c|c|c|}
\hline Mineral & $\begin{array}{l}\text { Chemical } \\
\text { Formula }\end{array}$ & Tank & Waste Type & Comments \\
\hline $\begin{array}{l}\text { Aluminum } \\
\text { oxide } \\
\text { (Boehmite) }\end{array}$ & $\mathrm{Al}(\mathrm{O}) \mathrm{OH}$ & S-101 & $\begin{array}{l}\text { Waste types: R (primary) and EB } \\
\text { (secondary). }\end{array}$ & $\begin{array}{l}\text { From PNNL-13394. Study undertaken to characterize solid phases } \\
\text { to understand better the enhanced sludge washing (ESW) and } \\
\text { leaching of Hanford material, to support waste treatment. Identified } \\
\text { only through TEM. Sludge solids. Seen in both direct-sampled } \\
\text { and caustic leached (at } 3 \mathrm{M} \text { concentration) materials. According to } \\
\text { the BBI database, the aluminum concentration is } 0.047 \mathrm{M} \text {, } \\
\text { suggesting sufficient aluminum for a solid, such as boehmite, to be } \\
\text { present. }\end{array}$ \\
\hline $\begin{array}{l}\text { Aluminum } \\
\text { oxide } \\
\text { (Boehmite) }\end{array}$ & $\mathrm{Al}(\mathrm{O}) \mathrm{OH}$ & S-104 & Sludge solids. Waste type is $\mathrm{R}$. & $\begin{array}{l}\text { From PNNL-13394. Study undertaken to characterize solid phases } \\
\text { to understand better the enhanced sludge washing (ESW) and } \\
\text { leaching of Hanford material, to support waste treatment. Identified } \\
\text { only through TEM. Sludge solids. Seen in both direct-sampled } \\
\text { and caustic leached ( } 3 \mathrm{M}) \text { materials. From BBI database, the g-Al/g- } \\
\text { solids value is } 0.045 \text {, thus sufficient quantity for boehmite formation } \\
\text { exist in this tank. }\end{array}$ \\
\hline
\end{tabular}


Table 1-1. Crystalline phases identified in Hanford tank waste samples. (56 pages)

\begin{tabular}{|c|c|c|c|c|}
\hline Mineral & $\begin{array}{l}\text { Chemical } \\
\text { Formula }\end{array}$ & Tank & Waste Type & Comments \\
\hline Gibbsite & $\mathrm{Al}(\mathrm{OH}) 3$ & S-110 & $\begin{array}{l}\text { R1 plus Some CWR1 sludge waste types, } \\
\text { cores } 240 \text { and } 241 \text {. The sample was an } \\
\text { amalgam of these waste types. }\end{array}$ & $\begin{array}{l}\text { From PNNL-13702. The purpose of the study was to measure } \\
\text { caustic leach factors to serve as a baseline for the process flowsheet. } \\
\text { The reference provided very little supporting information for this } \\
\text { identification, simply stated that it was identified by XRD. } \\
\text { However, caustic leach data presented for the data did indicate there } \\
\text { was a source of rapidly leached aluminum in the sample, consistent } \\
\text { with gibbsite. The TWINS inventory indicated a concentration of } \\
\text { aluminum of } 0.04 \mathrm{~g}-\mathrm{Al} / \mathrm{g} \text {-solids. } \\
\text { Also confirmed in: From PNNL-14018. Caustic leaching performed } \\
\text { to support process flowsheet development. Crystal phase identified } \\
\text { from XRD. Washed thrice with } 0.01 \mathrm{M} \text { NaOH. Composite waste } \\
\text { type of A1, A2, B, S1, S2, and R saltcakes. Residual solids } \\
\text { analyzed. }\end{array}$ \\
\hline
\end{tabular}


Table 1-1. Crystalline phases identified in Hanford tank waste samples. (56 pages)

\begin{tabular}{|c|c|c|c|c|}
\hline Mineral & $\begin{array}{l}\text { Chemical } \\
\text { Formula }\end{array}$ & Tank & Waste Type & Comments \\
\hline $\begin{array}{l}\text { Sodium } \\
\text { oxalate } \\
\text { (natroxalate) }\end{array}$ & $\mathrm{Na}_{2} \mathrm{C}_{2} \mathrm{O}_{4}$ & S-110 & $\begin{array}{l}\text { Evaporated precipitated mixture of S- } 110 \\
\text { and U- } 107 \text { supernate materials obtained } \\
\text { originally from cascade dissolution. }\end{array}$ & $\begin{array}{l}\text { From HNF-11585. } \\
\text { Purpose of study was to measure physical and chemical data for } \\
\text { support of Hanford waste retrieval and remediation. This crystal is } \\
\text { difficult to conclusively distinguish from sodium carbonate using } \\
\text { PLM and SEM-EDS. However, it has a definitive XRD pattern that } \\
\text { can be used to confirm its presence. Confirmed by PLM, SEM-EDS, } \\
\text { and XRD. The TWINS inventory indicated a concentration of } \\
\text { oxalate of } 0.002 \mathrm{~g} / \mathrm{g} \text {-solids. Although this value is somewhat low, } \\
\text { precipitation of solids will increase the abundance of this material. }\end{array}$ \\
\hline $\begin{array}{l}\text { Sodium nitrate } \\
\text { (nitratine) }\end{array}$ & $\mathrm{NaNO}_{3}$ & S-112 & R1 sludge solids waste type. & $\begin{array}{l}\text { From CH2M-0400924. Core } 292 \text { segment } 5 \text { material. Sample was } \\
\text { resistant to water sluicing dissolution, and contained yellow solid } \\
\text { residue. SEM-EDS and XRD were used to analyze and identify } \\
\text { solid material contained in a solid residue in the S- } 112 \text { tank. The } \\
\text { sodium nitrate (major) phase was at } 47 \mathrm{wt} \% \text { solids basis. } \\
\text { According to the BBI database, for R } 1 \text { the nitrate concentration is } \\
140 \mathrm{~g} / \mathrm{L} \text {. }\end{array}$ \\
\hline $\begin{array}{l}\text { Sodium } \\
\text { carbonate } \\
\text { (thermonatrite) }\end{array}$ & $\mathrm{Na}_{2} \mathrm{CO}_{3}-\mathrm{H}_{2} \mathrm{O}$ & S-112 & $\begin{array}{l}\text { Sample was resistant to water sluicing } \\
\text { dissolution, and primarily contained yellow } \\
\text { solid residue, as part of R1 sludge solids } \\
\text { waste type. }\end{array}$ & $\begin{array}{l}\text { From CH2M-0400924. Core } 292 \text { segment } 5 \text { material. Sample was } \\
\text { resistant to water sluicing dissolution, and contained yellow solid } \\
\text { residue. SEM-EDS and XRD were used to analyze and identify } \\
\text { solid material contained in a solid residue in the S- } 102 \text { tank. The } \\
\text { sodium carbonate was the third most abundant phase at } 8.9 \text { wt. } \% \text {. } \\
\text { According to the BBI database, for R } 1 \text { the carbonate concentration is } \\
\text { only } 0.23 \mathrm{~g} / \mathrm{L} \text {. This is too low to account for the presence of this } \\
\text { solid. Perhaps atmospheric carbon dioxide could have absorbed into } \\
\text { the caustic sample precipitating thermonatrite. }\end{array}$ \\
\hline
\end{tabular}


Table 1-1. Crystalline phases identified in Hanford tank waste samples. (56 pages)

\begin{tabular}{|c|c|c|c|c|}
\hline Mineral & $\begin{array}{l}\text { Chemical } \\
\text { Formula }\end{array}$ & Tank & Waste Type & Comments \\
\hline Sodium nitrite & $\mathrm{NaNO}_{2}$ & S-112 & $\begin{array}{l}\text { Sample was resistant to water sluicing } \\
\text { dissolution, and primarily contained yellow } \\
\text { solid residue, as part of R1 sludge solids } \\
\text { waste type. }\end{array}$ & $\begin{array}{l}\text { From CH2M-0400924. Core } 292 \text { segment } 5 \text { material. Sample was } \\
\text { resistant to water sluicing dissolution, and contained yellow solid } \\
\text { residue. SEM-EDS and XRD were used to analyze and identify } \\
\text { solid material contained in a solid residue in the S- } 102 \text { tank. The } \\
\text { sodium nitrite was the fifth most abundant phase at } 1.9 \mathrm{wt} . \% \text {. } \\
\text { According to the BBI database, for R1 the nitrite concentration is } 35 \\
\mathrm{~g} / \mathrm{L} \text {, sufficient for solids to form. }\end{array}$ \\
\hline Burkeite & $\mathrm{Na}_{6} \mathrm{CO}_{3}\left(\mathrm{SO}_{4}\right)_{2}$ & S-112 & $\begin{array}{l}\text { Sample was resistant to water sluicing } \\
\text { dissolution, and primarily contained yellow } \\
\text { solid residue, as part of R1 sludge solids } \\
\text { waste type. }\end{array}$ & $\begin{array}{l}\text { From CH2M-0400924. Core } 292 \text { segment } 5 \text { material. SEM-EDS } \\
\text { and XRD were used to analyze and identify solid material contained } \\
\text { in a solid residue in the S- } 102 \text { tank. The sodium carbonate-sulfate } \\
\text { phase was the second most abundant phase at } 9.8 \mathrm{wt} . \% \text { According } \\
\text { to TWINS inventory, carbonate has not been measured in the } \\
\text { supernate, however sulfate possesses a high concentration of } 6.4 \mathrm{~g} / \mathrm{L} \\
\text { and in the solid fraction } 0.11 \mathrm{~g}-\mathrm{SO} 4 / \mathrm{g} \text {-solids. According to the BBI } \\
\text { database, for R1 the carbonate concentration is only } 0.23 \mathrm{~g} / \mathrm{L} \text {. This } \\
\text { makes the high abundance of this material, for this tank, somewhat } \\
\text { surprising. }\end{array}$ \\
\hline $\begin{array}{l}\text { Sodium } \\
\text { chromate }\end{array}$ & $\mathrm{Na}_{2} \mathrm{CrO}_{4}$ & S-112 & $\begin{array}{l}\text { Sample was resistant to water sluicing } \\
\text { dissolution, and primarily contained yellow } \\
\text { solid residue, as part of R1 sludge solids } \\
\text { waste type. }\end{array}$ & $\begin{array}{l}\text { From CH2M- } 0400924 \text {. Core } 292 \text { segment } 5 \text { material. SEM-EDS } \\
\text { and XRD were used to analyze and identify solid material contained } \\
\text { in a solid residue in the S- } 102 \text { tank. Only a trace amount of } \mathrm{Na}_{2} \mathrm{CrO}_{4} \\
\text { observed. The yellow color was due to a chromate solid phase. }\end{array}$ \\
\hline $\begin{array}{l}\text { Sodium } \\
\text { phosphate }\end{array}$ & $\mathrm{Na}_{3} \mathrm{PO}_{4}$ & S-112 & $\begin{array}{l}\text { Sample was resistant to water sluicing } \\
\text { dissolution, and primarily contained yellow } \\
\text { solid residue, as part of R1 sludge solids } \\
\text { waste type. }\end{array}$ & $\begin{array}{l}\text { From CH2M-0400924. Core } 292 \text { segment } 5 \text { material. SEM-EDS } \\
\text { and XRD were used to analyze and identify solid material contained } \\
\text { in a solid residue in the S-102 tank. Only a trace amount of } \mathrm{Na}_{3} \mathrm{PO}_{4} \\
\text { observed. }\end{array}$ \\
\hline
\end{tabular}


Table 1-1. Crystalline phases identified in Hanford tank waste samples. (56 pages)

\begin{tabular}{|c|c|c|c|c|}
\hline Mineral & $\begin{array}{l}\text { Chemical } \\
\text { Formula }\end{array}$ & Tank & Waste Type & Comments \\
\hline $\begin{array}{l}\text { Sodium } \\
\text { oxalate } \\
\text { (natroxalate) }\end{array}$ & $\mathrm{Na}_{2} \mathrm{C}_{2} \mathrm{O}_{4}$ & S-112 & $\begin{array}{l}\text { Sample was resistant to water sluicing } \\
\text { dissolution, and primarily contained yellow } \\
\text { solid residue, as part of R1 sludge solids } \\
\text { waste type. }\end{array}$ & $\begin{array}{l}\text { From CH2M- } 0400924 \text {. Core } 292 \text { segment } 5 \text { material. SEM-EDS } \\
\text { and XRD were used to analyze and identify solid material contained } \\
\text { in a solid residue in the S-102 tank. Only a trace amount of } \mathrm{Na}_{2} \mathrm{C}_{2} \mathrm{O}_{4} \\
\text { observed. }\end{array}$ \\
\hline $\begin{array}{l}\mathrm{Al}-\mathrm{Cr} \\
\text { particulates }\end{array}$ & $\begin{array}{l}\text { Al-Cr rich } \\
\text { amorphous } \\
\text { phase }\end{array}$ & S-112 & $\begin{array}{l}\text { R1 sludge solids exist in S-112 according to } \\
\text { BBI at heel level of } 8.6 \mathrm{~kL} \text {. }\end{array}$ & $\begin{array}{l}\text { From FH-0202771. } \\
\text { Caustic dissolution experiment. Techniques of PLM, SEM-EDS, } \\
\text { and XRD used to investigate solid composition/crystal type. Report } \\
\text { states solid saltcake waste type. From TWINS inventory, the } \mathrm{Al} \text { and } \\
\mathrm{Cr} \text { concentrations are listed as } 0.22 \mathrm{~g}-\mathrm{Al} / \mathrm{g} \text {-solids and } 0.005 \mathrm{~g}-\mathrm{Cr} / \mathrm{g}- \\
\text { solids, respectively. These high concentrations are consistent with } \\
\text { presence of this phase. }\end{array}$ \\
\hline $\begin{array}{l}\text { Sodium } \\
\text { diuranate }\end{array}$ & $\mathrm{Na}_{2} \mathrm{U}_{2} \mathrm{O}_{7}$ & S-112 & $\begin{array}{l}\text { R1 sludge solids exist in S-112 according to } \\
\text { BBI at heel level of } 8.6 \mathrm{~kL} \text {. }\end{array}$ & $\begin{array}{l}\text { From FH-0202771. Techniques of PLM, SEM-EDS, and XRD used } \\
\text { to investigate solid composition/crystal type. Less than } 5 \text { microns in } \\
\text { diameter for these crystals. Solid saltcake caustic dissolution in } \\
\text { water and } 2 \mathrm{M} \mathrm{NaOH} \text {, cores } 291 \text { and } 292 \text {. Report states solid } \\
\text { saltcake waste type. From TWINS inventory, the concentration of U } \\
\text { is } 0.0048 \mathrm{~g} \text {-U/g-solids. This high concentration is consistent with } \\
\text { the common form of uranium. }\end{array}$ \\
\hline $\begin{array}{l}\mathrm{Ca}-\mathrm{Cr} \\
\text { crystallites }\end{array}$ & $\mathrm{Ca}_{3} \mathrm{Cr}_{2}(\mathrm{OH})_{12}$ & S-112 & $\begin{array}{l}\text { R1 sludge solids exist in S-112 according to } \\
\text { BBI at heel level of } 8.6 \mathrm{~kL} \text {. }\end{array}$ & $\begin{array}{l}\text { From FH-0202771. Techniques of PLM, SEM-EDS, and XRD used } \\
\text { to investigate solid composition/crystal type. Particulates generally } \\
\text { less than } 10 \text { microns in size. Solid saltcake caustic dissolution in } \\
\text { water and } 2 \mathrm{M} \mathrm{NaOH} \text {, cores } 291 \text { and } 292 \text {. Report states solid } \\
\text { saltcake waste type. From the TWINS inventory, the concentrations } \\
\text { of } \mathrm{Ca} \text { and } \mathrm{Cr} \text { are } 0.0021 \mathrm{~g} \text {-Ca/g-solids and } 0.005 \mathrm{~g} \text {-Cr/g-solids, } \\
\text { respectively. These are sufficient for the presence of this hydroxide } \\
\text { phase. }\end{array}$ \\
\hline
\end{tabular}


Table 1-1. Crystalline phases identified in Hanford tank waste samples. (56 pages)

\begin{tabular}{|c|c|c|c|c|}
\hline $\begin{array}{l}\text { Lithium } \\
\text { aluminum } \\
\text { hydroxide }\end{array}$ & $\begin{array}{l}\mathrm{LiAl}_{2}(\mathrm{OH})_{7^{-}}^{-} \\
\mathrm{nH}_{2} \mathrm{O}\end{array}$ & S-112 & $\begin{array}{l}\text { R1 sludge solids exist in S-112 according to } \\
\text { BBI at heel level of } 8.6 \mathrm{~kL} \text {. }\end{array}$ & $\begin{array}{l}\text { From FH-0202771. Techniques of PLM, SEM-EDS, and XRD used } \\
\text { to investigate solid composition/crystal type. Identified in only one } \\
\text { sample. This seems to be a new/unique crystal type. Solid saltcake } \\
\text { caustic dissolution in water and } 2 \mathrm{MNaOH} \text {, cores } 291 \text { and } 292 \text {. }\end{array}$ \\
\hline $\begin{array}{l}\text { Sodium } \\
\text { carbonate } \\
\text { hydrate }\end{array}$ & $\mathrm{Na}_{2} \mathrm{CO}_{3}-\mathrm{H}_{2} \mathrm{O}$ & S-112 & $\begin{array}{l}\text { Report states that identification of waste } \\
\text { type not possible [see HNF-11585], } \\
\text { although R1 sludge is known to exist in S- } \\
112 \text { at } 8.6 \mathrm{~kL} \text { heel level. }\end{array}$ & $\begin{array}{l}\text { From HNF-11585. Purpose of study was to measure physical and } \\
\text { chemical data for support of Hanford waste retrieval and } \\
\text { remediation. Use of polarized light microscopy (PLM), SEM-EDS, } \\
\text { and XRD was used to confirm crystal type. Crystals formed from } \\
\text { precipitated supernate following cascade water dissolution of } \\
\text { composite saltcake. According to the BBI database, for R1 the } \\
\text { carbonate concentration is } 0.23 \mathrm{~g} / \mathrm{L} \text {, consistent with solids } \\
\text { precipitated from concentrated supernatant but not supernate present } \\
\text { in the tank. }\end{array}$ \\
\hline
\end{tabular}


Table 1-1. Crystalline phases identified in Hanford tank waste samples. (56 pages)

\begin{tabular}{|l|l|l|l|l|}
\hline Mineral & $\begin{array}{l}\text { Chemical } \\
\text { Formula }\end{array}$ & Tank & Waste Type & \multicolumn{1}{|c|}{ Comments } \\
\hline $\begin{array}{l}\text { Hydrogarnet- } \\
\text { hydrouvarovite }\end{array}$ & $\begin{array}{l}\text { Likely to be } \\
(\mathrm{Ca}, \mathrm{Sr})_{3} \\
(\mathrm{Cr}, \mathrm{AI})_{2}(\mathrm{OH})_{12}\end{array}$ & $\mathrm{~S}-112$ & $\begin{array}{l}\text { R1 waste type obtained from incomplete } \\
\text { (cascade) dissolution of sludge material. }\end{array}$ & $\begin{array}{l}\text { From HNF-11585. } \\
\text { Purpose of study was to measure physical and chemical data for } \\
\text { support of Hanford waste retrieval and remediation. The second of } \\
\text { two novel phases from this report is a distinctive chemical } \\
\text { combination of calcium, strontium, chromium } \\
\text { and aluminum. XRD analysis indicates that this compound has a } \\
\text { crystalline structure that is consistent with the garnet group of } \\
\text { minerals. If so, then this phase is identified as a previously unknown } \\
\text { hydrogarnet- hydrouvarovite compound. Caustic leaching of solid } \\
\text { material. BBI Waste Type Template document [RPP-8847] suggests } \\
\text { that these minerals are in great enough abundance (Ca,Al) to be } \\
\text { identifiable in a washed saltcake sample. }\end{array}$ \\
\hline Gibbsite & Al(OH) $)_{3}$ & S-112 & $\begin{array}{l}\text { Cladding Waste (CWR) and S Saltcake } \\
\text { from report. However, BBI only has R1 } \\
\text { sludge solids in tank S-112 at } 8.6 \mathrm{~kL} \text { heel } \\
\text { level. }\end{array}$ & $\begin{array}{l}\text { From PNNL-17593. Study purpose was to assess leachability of } \\
\text { components from tank waste solids. Identified by XRD and SEM. } \\
\text { This phase was also found in the water-washed residues after } \\
\text { laboratory simulation of the retrieval process reported in FH- } \\
\text { 0202771. Gibbsite was the dominant mineral in the sludge. The } \\
\text { gibbsite was usually coated with a Na-Al bearing phase, probably } \\
\text { dawsonite. Heel after retrieval. From TWINS total inventory, the } \\
\text { Al concentration is listed as 0.22 g-Al/g-solids, which could be } \\
\text { responsible for the presence of gibbsite. }\end{array}$ \\
\hline
\end{tabular}


Table 1-1. Crystalline phases identified in Hanford tank waste samples. (56 pages)

\begin{tabular}{|l|l|l|l|l|}
\hline Mineral & $\begin{array}{l}\text { Chemical } \\
\text { Formula }\end{array}$ & Tank & Waste Type & \multicolumn{1}{|c|}{ Comments } \\
\hline & & & $\begin{array}{l}\text { Waste type is R1 sludge according to BBI. } \\
\text { Pre-leaching particle types identified here. }\end{array}$ & $\begin{array}{l}\text { From 74A10-WSC-08-152. Purpose of the study was to determine } \\
\text { the physical nature of the material in the tank after retrieval } \\
\text { operations. This is a necessary step in tank closure. The techniques } \\
\text { of PLM, SEM-EDS, and XRD confirmed the analysis of material as } \\
\text { Gibbsite, with dimensions as large as 100 } \mu \text { (larger than typically } \\
\text { seen). This was major component. Caustic dissolution identified } \\
\text { the material as sludge solids, not saltcake. This is contrary to prior } \\
\text { studies. From TWINS inventory, however, the Al concentration is } \\
\text { listed as 0.22 g-Al/g-solids, that could be responsible for the } \\
\text { presence of gibbsite. }\end{array}$ \\
\hline Dawsonite & $\mathrm{NaAl(OH)CO} 3$ & S-112 & $\begin{array}{l}\text { Heel after retrieval of REDOX Process, R1 } \\
\text { sludge solids in tank S-112. }\end{array}$ & $\begin{array}{l}\text { From PNNL-17593. } \\
\text { Study purpose was to assess leachability of components from tank } \\
\text { waste solids. This is a speculative identification based on SEM. The } \\
\text { SEM identified a phase that coated the gibbsite particles made up of } \\
\text { Na and Al. Dawsonite is the most reasonable identification for this } \\
\text { phase because sodium aluminate would be too soluble to be in the } \\
\text { waste. From TWINS inventory, however, the Al concentration is } \\
\text { listed as 0.22 g-Al/g-solids, together with high carbonate, supports } \\
\text { the presence of Dawsonite. }\end{array}$ \\
\hline
\end{tabular}


Table 1-1. Crystalline phases identified in Hanford tank waste samples. (56 pages)

\begin{tabular}{|c|c|c|c|c|}
\hline Mineral & $\begin{array}{l}\text { Chemical } \\
\text { Formula }\end{array}$ & Tank & Waste Type & Comments \\
\hline Gibbsite & $\mathrm{Al}(\mathrm{OH}) 3$ & S-112 & R1 sludge solids. & $\begin{array}{l}\text { 74A10-WSC-08-152. } \\
\text { Purpose of the study was to determine the physical nature of the } \\
\text { material in the tank after retrieval operations. This is a necessary } \\
\text { step in tank closure. The techniques of PLM, SEM-EDS, and XRD } \\
\text { confirmed the analysis of crystalline material. Three experiments } \\
\text { performed: (1) direct composite solids; (2) water solubility tests; and } \\
\text { (3) caustic digest ( } 19 \mathrm{M}) \text { NaOH. Gibbsite was identified as a major } \\
\text { component. From TWINS inventory, however, the Al concentration } \\
\text { is listed as } 0.22 \mathrm{~g}-\mathrm{Al} / \mathrm{g} \text {-solids, which could be responsible for the } \\
\text { presence of gibbsite. Caustic dissolution identified the material as } \\
\text { sludge solids, not saltcake. This is contrary to prior studies. Pre- } \\
\text { leaching particle types identified here. }\end{array}$ \\
\hline $\begin{array}{l}\text { Sodium } \\
\text { diuranate }\end{array}$ & $\mathrm{Na}_{2} \mathrm{U}_{2} \mathrm{O}_{7}$ & S-112 & $\begin{array}{l}\text { Heel after retrieval of REDOX Process, } \\
\text { Cladding Waste (CWR) and S Saltcake. } \\
\text { However, BBI only has R1 sludge solids } \\
\text { contained in tank S-112. }\end{array}$ & $\begin{array}{l}\text { See report FH-0202771. } \\
\text { The experiment took saltcake from a sample taken prior to retrieving } \\
\text { the tank and dissolved the saltcake in water. The sodium diuranate } \\
\text { was identified in residuals that did not dissolve in water by XRD and } \\
\text { SEM. This phase was not identified in the heel samples evaluated in } \\
\text { PNNL-17593, probably because there was little uranium found in the } \\
\text { heel samples. Nonetheless, what little uranium that is in the heel of } \\
\text { S-112 is likely in the form of sodium diuranate, given it was } \\
\text { conclusively identified in the report FH- } 0202771 \text {. The sodium } \\
\text { diuranate was extrem ely small, } 4 \text { microns by SEM, so most of the } \\
\text { uranium likely was suspended in the retrieval fluid, given the small } \\
\text { abundance in the heel. }\end{array}$ \\
\hline
\end{tabular}


Table 1-1. Crystalline phases identified in Hanford tank waste samples. (56 pages)

\begin{tabular}{|c|c|c|c|c|}
\hline Mineral & $\begin{array}{l}\text { Chemical } \\
\text { Formula }\end{array}$ & Tank & Waste Type & Comments \\
\hline $\begin{array}{l}\text { Sodium nitrate } \\
\text { (nitratine) }\end{array}$ & $\mathrm{NaNO}_{3}$ & S-112 & $\begin{array}{l}\text { S Saltcake waste type from report [CH2M- } \\
\text { 0400924]. However, BBI only has R1 } \\
\text { sludge solids in tank S-112 (e.g., no } \\
\text { saltcake). }\end{array}$ & $\begin{array}{l}\text { See report CH2M-0 } 0400924 \text {. Core } 292 \text { segment } 5 \text { material. SEM- } \\
\text { EDS and XRD were used to analyze and identify solid material } \\
\text { contained in a solid residue in the S- } 112 \text { tank. This was identified by } \\
\text { XRD. This was identified in the saltcake, which has since been } \\
\text { dissolved. Consequently, there is little chance that such a soluble } \\
\text { phase would still be present in the heel in S-112, but is indicative of } \\
\text { what might be present in other S saltcakes or what might precipitate } \\
\text { if this waste is ever concentrated, say through evaporation, again. } \\
\text { Approximately } 47 \text { wt. } \% \text { abundant. }\end{array}$ \\
\hline $\begin{array}{l}\text { Thermonatrite } \\
\text { (sodium } \\
\text { carbonate } \\
\text { monohydrate) }\end{array}$ & $\mathrm{Na}_{2} \mathrm{CO}_{3}-\mathrm{H} 2 \mathrm{O}$ & S-112 & $\begin{array}{l}\text { S Saltcake waste type from report [CH2M- } \\
\text { 0400924]. However, BBI only has R1 } \\
\text { sludge solids in tank S-112 (e.g., no } \\
\text { saltcake). }\end{array}$ & $\begin{array}{l}\text { See report CH2M-0400924. Core } 292 \text { segment } 5 \text { material. SEM- } \\
\text { EDS and XRD were used to analyze and identify solid material } \\
\text { contained in a solid residue in the S- } 112 \text { tank. This was identified by } \\
\text { XRD. This was identified in the saltcake, which has since been } \\
\text { dissolved. Consequently, there is little chance that such a soluble } \\
\text { phase would still be present in the heel in S-112, but is indicative of } \\
\text { what might be present in other S saltcakes or what might precipitate } \\
\text { if this waste is ever concentrated again. Approximately } 9 \text { wt.\% } \\
\text { abundant. } \\
\text { Also confirmed in: 74A10-WSC-08-152. Purpose of the study was } \\
\text { to determine the physical nature of the material in the tank after } \\
\text { retrieval operations. This is a necessary step in tank closure. The } \\
\text { techniques of PLM, SEM-EDS, and XRD confirmed the analysis of } \\
\text { crystalline material. Three experiments performed: (1) direct } \\
\text { composite solids; (2) water solubility tests; and (3) caustic digest (19 } \\
\text { M) NaOH. Trace amount of sodium carbonate detected. Pre- } \\
\text { leaching particle types identified here. }\end{array}$ \\
\hline
\end{tabular}


Table 1-1. Crystalline phases identified in Hanford tank waste samples. (56 pages)

\begin{tabular}{|c|c|c|c|c|}
\hline Mineral & $\begin{array}{l}\text { Chemical } \\
\text { Formula }\end{array}$ & Tank & Waste Type & Comments \\
\hline Sodium Nitrite & $\mathrm{NaNO}_{2}$ & S-112 & $\begin{array}{l}\text { S Saltcake waste type from report [CH2M- } \\
0400924] \text {. However, BBI only has R1 } \\
\text { sludge solids in tank S-112 (e.g., no } \\
\text { saltcake). }\end{array}$ & $\begin{array}{l}\text { See report CH2M- } 0400924 \text {. Core } 292 \text { segment } 5 \text { material. SEM- } \\
\text { EDS and XRD were used to analyze and identify solid material } \\
\text { contained in a solid residue in the S-112 tank. This was identified by } \\
\text { XRD. This was identified in the saltcake, which has since been } \\
\text { dissolved. Consequently, there is little chance that such a soluble } \\
\text { phase would still be present in the heel in S-112, but is indicative of } \\
\text { what might be present in other S saltcakes or what might precipitate } \\
\text { if this waste is ever concentrated again. Approximately } 2 \text { wt. } \% \\
\text { abundant. }\end{array}$ \\
\hline \multirow[t]{2}{*}{$\begin{array}{l}\text { Burkeite } \\
\text { (sodium } \\
\text { carbonate } \\
\text { sulfate) }\end{array}$} & $\mathrm{Na}_{6} \mathrm{CO}_{3}\left(\mathrm{SO}_{4}\right)_{2}$ & S-112 & $\begin{array}{l}\text { S Saltcake waste type from report [CH2M- } \\
0400924] . \text { However, BBI only has R1 } \\
\text { sludge solids in tank S-112 (e.g., no } \\
\text { saltcake). }\end{array}$ & $\begin{array}{l}\text { See report CH2M- } 0400924 \text {. Core } 292 \text { segment } 5 \text { material. SEM- } \\
\text { EDS and XRD were used to analyze and identify solid material } \\
\text { contained in a solid residue in the S-112 tank. This was identified by } \\
\text { XRD. This was identified in the saltcake, which has since been } \\
\text { dissolved. Consequently, there is little chance that such a soluble } \\
\text { phase would still be present in the heel in S-112, but is indicative of } \\
\text { what might be present in other S saltcakes or what might precipitate } \\
\text { if this waste is ever concentrated again. Approximately } 10 \text { wt.\% } \\
\text { abundant. }\end{array}$ \\
\hline & & & $\begin{array}{l}\text { NA saltcake from concentrated NA- } \\
\text { supernate. In support of retrieval. }\end{array}$ & $\begin{array}{l}\text { From HNF-11585. Purpose of study was to measure physical and } \\
\text { chemical data for support of Hanford waste retrieval and } \\
\text { remediation. The reference used XRD and PLM to identify solids in } \\
\text { dissolved saltcake sample. From TWINS inventory, however, the Al } \\
\text { concentration is listed as } 0.10 \mathrm{~g}-\mathrm{SO} 4 / \mathrm{mL} \text {, together with high } \\
\text { carbonate, supports the presence of mineral phase. }\end{array}$ \\
\hline
\end{tabular}


Table 1-1. Crystalline phases identified in Hanford tank waste samples. (56 pages)

\begin{tabular}{|c|c|c|c|c|}
\hline Mineral & $\begin{array}{l}\text { Chemical } \\
\text { Formula }\end{array}$ & Tank & Waste Type & Comments \\
\hline $\begin{array}{l}\text { Aluminum } \\
\text { hydroxide } \\
\text { (gibbsite) }\end{array}$ & $\mathrm{Al}(\mathrm{OH})_{3}$ & SX-101 & $\begin{array}{l}\text { NA saltcake from concentrated NA- } \\
\text { supernate. In support of retrieval. }\end{array}$ & $\begin{array}{l}\text { From HNF-11585. Purpose of study was to measure physical and } \\
\text { chemical data for support of Hanford waste retrieval and } \\
\text { remediation. The compound } \mathrm{Al}(\mathrm{OH})_{3} \text { occurs in several forms. The } \\
\text { phases gibbsite, bayerite, and amorphous aluminum hydroxide have } \\
\text { been observed in Hanford tank wastes. In addition, Norstrandite and } \\
\text { doyleite are the names of two other possible crystallographic forms } \\
\text { of } \mathrm{Al}(\mathrm{OH})_{3} \text {. } \\
\text { Its crystals are generally too small to characterize by PLM, however } \\
\text { XRD provides a good analysis technique. Gibbsite identified by } \\
\text { XRD. Crystals remaining following cascade water dissolution of } \\
\text { composite saltcake. From TWINS database, the aluminum total } \\
\text { concentration in the solids is approximately } 0.06 \text { g-Al/g-solids. }\end{array}$ \\
\hline Sodium nitrite & $\mathrm{NaNO}_{2}$ & SX-101 & $\begin{array}{l}\text { Waste type not specified. From Best Basis } \\
\text { Inventory must be R, R1, S1, and/or S2 } \\
\text { waste type(s). }\end{array}$ & $\begin{array}{l}\text { From HNF-13805. } \\
\text { Both simulant formed sodium nitrite solid particulates and those } \\
\text { obtained from tank SX-101 via direct analyses have been compared. } \\
\text { No additional corroboration, say from SEM-EDS or XRD was } \\
\text { mentioned. From TWINS database, the nitrite total concentration in } \\
\text { the solids is approximately } 0.04 \text { g-NO2/g-solids, so it is a substantial } \\
\text { fraction of the solids. }\end{array}$ \\
\hline $\begin{array}{l}\text { Aluminum } \\
\text { oxide } \\
\text { (Boehmite) }\end{array}$ & $\mathrm{Al}(\mathrm{O}) \mathrm{OH}$ & SX-108 & R sludge solids. & $\begin{array}{l}\text { From PNNL-13394. Study undertaken to characterize solid phases } \\
\text { to understand better the enhanced sludge washing (ESW) and } \\
\text { leaching of Hanford material, to support waste treatment. Identified } \\
\text { only through TEM. Sludge solids. Seen in both direct-sampled } \\
\text { and caustic leached ( } 3 \mathrm{M} \text { ) materials. From TWINS database, the } \\
\text { aluminum total concentration in the solids is approximately } 0.30 \mathrm{~g} \text { - } \\
\text { Al/g-solids. This high solids fraction explains it being a major } \\
\text { constituent. }\end{array}$ \\
\hline
\end{tabular}


Table 1-1. Crystalline phases identified in Hanford tank waste samples. (56 pages)

\begin{tabular}{|c|c|c|c|c|}
\hline Mineral & $\begin{array}{l}\text { Chemical } \\
\text { Formula }\end{array}$ & Tank & Waste Type & Comments \\
\hline $\begin{array}{l}\text { Sodium } \\
\text { oxalate } \\
\text { (natroxalate) }\end{array}$ & $\mathrm{Na}_{2} \mathrm{C}_{2} \mathrm{O}_{4}$ & SY-101 & $\begin{array}{l}\text { S1 saltcake. [see Esch, 2000; FH- } \\
\text { 0003514]. }\end{array}$ & $\begin{array}{l}\text { From RPP- } 6517 \text {. } \\
\text { Most abundant solid phase. Approximately } 40 \% \text { of solid phase for } \\
\text { this crystal type. From BBI database, solid composition has } 0.090 \mathrm{~g} \text { - } \\
\text { oxalate/g-solids. Therefore presence in solid phase well documented } \\
\text { in native tank waste material. }\end{array}$ \\
\hline $\begin{array}{l}\text { Sodium } \\
\text { phosphate } \\
\text { hydrate }\end{array}$ & $\begin{array}{l}\mathrm{Na}_{3} \mathrm{PO}_{4^{-}} \\
12 \mathrm{H}_{2} \mathrm{O}\end{array}$ & SY-101 & $\begin{array}{l}\text { S1 saltcake. [see Esch, 2000; FH- } \\
\text { 0003514]. }\end{array}$ & $\begin{array}{l}\text { From RPP- } 6517 \text {. } \\
\text { Third most abundant solid phase. Approximately } 20 \% \text { of solid } \\
\text { phase for this crystal type. From BBI Waste Template compositions } \\
\text { [RPP-8847], the phosphate solids composition is } 0.0044 \text { g-PO4/g- } \\
\text { solids. }\end{array}$ \\
\hline $\begin{array}{l}\text { Sodium } \\
\text { fluoride } \\
\text { phosphate }\end{array}$ & $\begin{array}{l}\mathrm{Na}_{7} \mathrm{~F}\left(\mathrm{PO}_{4}\right)_{2}^{-} \\
12 \mathrm{H}_{2} \mathrm{O}\end{array}$ & SY-101 & $\begin{array}{l}\text { S1 saltcake. [see Esch, 2000; FH- } \\
\text { 0003514]. }\end{array}$ & $\begin{array}{l}\text { From RPP- } 6517 \text {. } \\
\text { Fourth most abundant solid phase. Approximately } 10 \% \text { of solid } \\
\text { phase for this crystal type. From BBI Waste Template compositions } \\
\text { [RPP-8847], the phosphate solids composition is } 0.0044 \text { g-PO } 4 / \mathrm{g}- \\
\text { solids and the fluoride is } 0.000027 \mathrm{~g}-\mathrm{F} / \mathrm{g} \text {-solids. This supports } \\
\text { presence of solid phase, albeit in low abundance. }\end{array}$ \\
\hline
\end{tabular}


Table 1-1. Crystalline phases identified in Hanford tank waste samples. (56 pages)

\begin{tabular}{|c|c|c|c|c|}
\hline Mineral & $\begin{array}{l}\text { Chemical } \\
\text { Formula }\end{array}$ & Tank & Waste Type & Comments \\
\hline $\begin{array}{l}\text { Calcium } \\
\text { carbonate or } \\
\text { Calcium } \\
\text { oxalate }\end{array}$ & $\begin{array}{l}\mathrm{CaCO}_{3} \text { or } \\
\mathrm{CaC}_{2} \mathrm{O}_{4}\end{array}$ & SY-101 & $\begin{array}{l}\text { S1 saltcake. [see Esch, 2000; FH- } \\
\text { 0003514]. }\end{array}$ & $\begin{array}{l}\text { From RPP- } 6517 \text {. } \\
\text { Fifth most abundant solid phase. Approximately } 1 \% \text { (trace amount) } \\
\text { of solid phase for this crystal type. Identified by EDS only (e.g., no } \\
\text { imaging), so analysis technique cannot distinguish between } \\
\text { carbonate from oxalate. From BBI database, solid composition has } \\
0.00040 \text { g-calcium } / g \text {-solids. Therefore presence in solid phase well } \\
\text { documented in native tank waste material. Understandably less than } \\
\text { oxalate and gibbsite materials. }\end{array}$ \\
\hline $\begin{array}{l}\text { Sodium } \\
\text { fluoride } \\
\text { phosphate }\end{array}$ & $\begin{array}{l}\mathrm{Na}_{7} \mathrm{~F}\left(\mathrm{PO}_{4}\right)_{2}- \\
12 \mathrm{H}_{2} \mathrm{O}\end{array}$ & SY-102 & $\begin{array}{l}\text { Solids waste type, although not specified, is } \\
\text { likely NA sludge plus NA liquid. The other } \\
\text { possibility is R1 sludge, but due to the grab } \\
\text { sample location and amount of solids ( } 50- \\
50 \text { vol.\% solids-liquid), NA waste type is } \\
\text { most probable. }\end{array}$ & $\begin{array}{l}\text { From 7S110-DLH-05-041. Grab sample from Riser } 3 \text { (2SY-05-09). } \\
\text { Major phase. Identified by PLM and SEM-EDS, but not XRD. } \\
\text { Settled solids sample obtained from sampling } 6 \text { inches below liquid- } \\
\text { solid phase interface. Direct sampling of solids from collected slurry } \\
\text { sample. From TWINS database, the phosphate and fluoride } \\
\text { concentrations are } 0.008 \text { g-PO4/g-solids and } 0.0005 \mathrm{~g}-\mathrm{F} / \mathrm{g} \text {-solids. } \\
\text { The fluoride, although observed in the solids fraction, is somewhat } \\
\text { low for the observed abundance seen. }\end{array}$ \\
\hline
\end{tabular}


Table 1-1. Crystalline phases identified in Hanford tank waste samples. (56 pages)

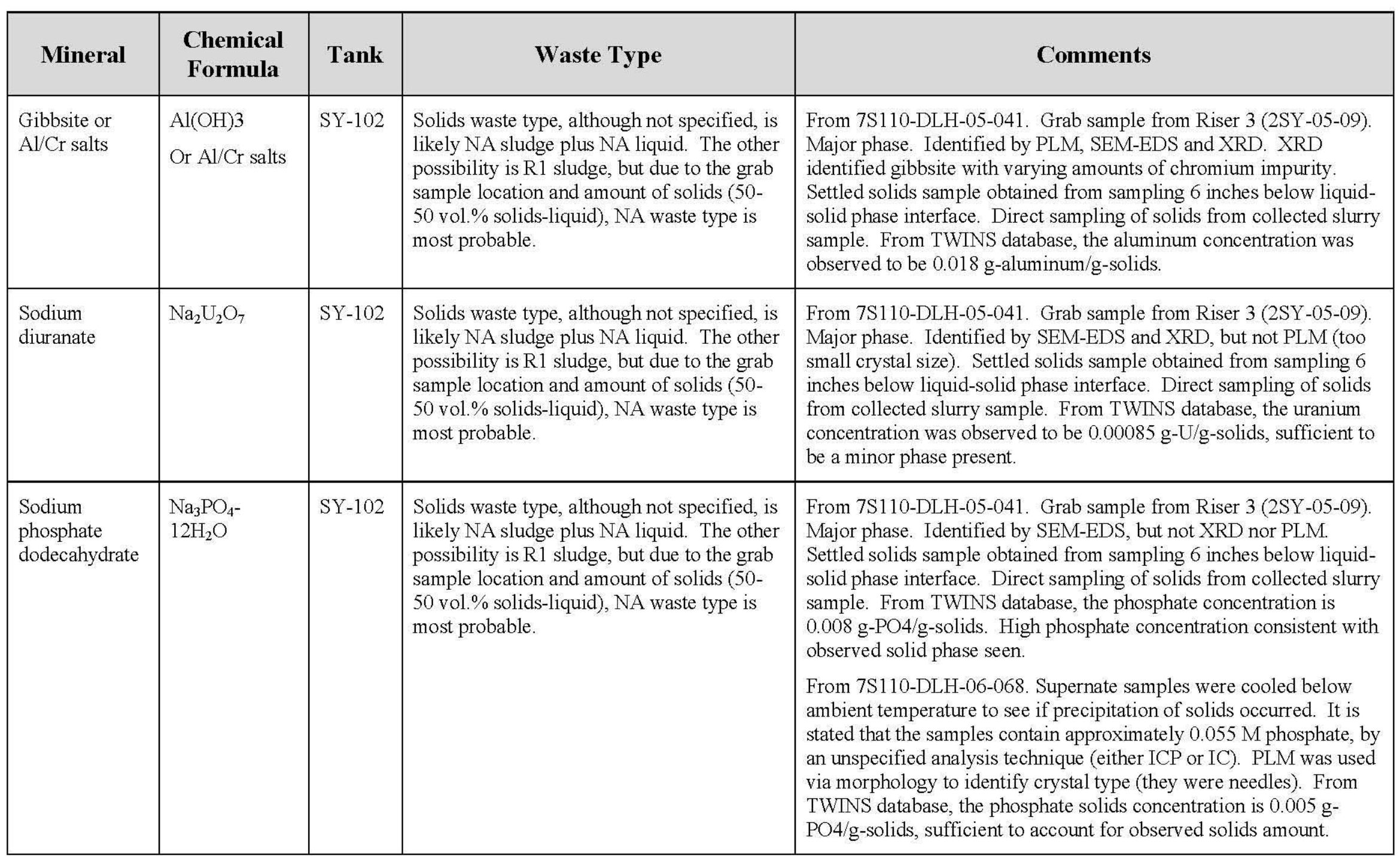


Table 1-1. Crystalline phases identified in Hanford tank waste samples. (56 pages)

\begin{tabular}{|c|c|c|c|c|}
\hline Mineral & $\begin{array}{l}\text { Chemical } \\
\text { Formula }\end{array}$ & Tank & Waste Type & Comments \\
\hline $\begin{array}{l}\text { Plutonium } \\
\text { oxide }\end{array}$ & $\mathrm{PuO}_{2}$ & SY-102 & $\begin{array}{l}\text { Not specified but likely NA sludge } \\
\text { centrifuged REDOX solids waste type. }\end{array}$ & $\begin{array}{l}\text { From CH2M-0 } 400872 \text {. Study characterized settling behavior of } \\
\text { plutonium oxide particles for criticality issue. } \mathrm{PuO}_{2} \text { comprised } 7.4 \\
\text { wt. } \% \text { of fines and } 5 \mathrm{wt} . \% \text { overall, and therefore are a substantial } \\
\text { amount of particulate material present. }\end{array}$ \\
\hline Gibbsite & $\mathrm{Al}(\mathrm{OH})_{3}$ & SY-103 & $\mathrm{CC}$ waste type sludge solids. & $\begin{array}{l}\text { From PNNL-13394. Study undertaken to characterize solid phases } \\
\text { to understand better the enhanced sludge washing (ESW) and } \\
\text { leaching of Hanford material, to support waste treatment. Identified } \\
\text { by TEM, SEM-EDS and XRD. Seen in both direct-sampled and } \\
\text { caustic leached ( } 3 \text { M) materials. }\end{array}$ \\
\hline Gibbsite & $\mathrm{Al}(\mathrm{OH})_{3}$ & T-104 & Sludge solids. Waste type is $1 \mathrm{C}$. & $\begin{array}{l}\text { From PNNL-13394. Study undertaken to characterize solid phases } \\
\text { to understand better the enhanced sludge washing (ESW) and } \\
\text { leaching of Hanford material, to support waste treatment. Identified } \\
\text { by TEM/SEM-EDS and XRD. Seen in direct-sampled, leached, } \\
\text { material. According to the BBI database, the aluminum solids } \\
\text { concentration is } 0.015 \mathrm{~g}-\mathrm{A} 1 / \mathrm{g} \text {-solids. This supports the high } \\
\text { abundance of this phase. }\end{array}$ \\
\hline $\begin{array}{l}\text { Aluminum } \\
\text { phosphate }\end{array}$ & $\mathrm{AlPO}_{4}$ & T-104 & 1C Sludge solids. & $\begin{array}{l}\text { From PNNL-13394. Study undertaken to characterize solid phases } \\
\text { to understand better the enhanced sludge washing (ESW) and } \\
\text { leaching of Hanford material, to support waste treatment. Identified } \\
\text { by TEM/SEM-EDS and XRD. Seen in direct-sampled material. } \\
\text { According to the BBI database, the aluminum solids concentration is } \\
0.015 \mathrm{~g}-\mathrm{Al} / \mathrm{g} \text {-solids and the PO4 concentration is } 0.069 \text { g-PO4/g- } \\
\text { solids. These high concentrations support the high abundance of this } \\
\text { phase. }\end{array}$ \\
\hline
\end{tabular}


Table 1-1. Crystalline phases identified in Hanford tank waste samples. (56 pages)

\begin{tabular}{|c|c|c|c|c|}
\hline Mineral & $\begin{array}{l}\text { Chemical } \\
\text { Formula }\end{array}$ & Tank & Waste Type & Comments \\
\hline Aluminosilicates & $\begin{array}{l}\text { Al-Si-O } \\
\text { zeolite }\end{array}$ & T-104 & 1C Sludge solids. & $\begin{array}{l}\text { From PNNL-13394. Study undertaken to characterize solid phases } \\
\text { to understand better the enhanced sludge washing (ESW) and } \\
\text { leaching of Hanford material, to support waste treatment. Identified } \\
\text { by TEM/SEM-EDS and XRD. Seen in both direct-sampled and } \\
\text { caustic leached ( } 3 \mathrm{M} \text { ) materials. According to the BBI database, the } \\
\text { aluminum solids concentration is } 0.015 \mathrm{~g} \text {-Al/g-solids and the silicon } \\
\text { concentration is } 0.0062 \mathrm{~g} \text {-Si/g-solids. These high concentrations } \\
\text { support the moderate abundance of this phase. }\end{array}$ \\
\hline $\begin{array}{l}\text { Sodium iron } \\
\text { aluminum } \\
\text { phosphate }\end{array}$ & $\begin{array}{l}\mathrm{Na}_{2} \mathrm{Fe}_{2} \\
\mathrm{Al}\left(\mathrm{PO}_{4}\right)_{3}\end{array}$ & T-104 & 1C Sludge solids. & $\begin{array}{l}\text { From PNNL-13394. Study undertaken to characterize solid phases } \\
\text { to understand better the enhanced sludge washing (ESW) and } \\
\text { leaching of Hanford material, to support waste treatment. Identified } \\
\text { by TEM/SEM-EDS and XRD. Seen in direct-sampled material. } \\
\text { According to the BBI database, the aluminum solids concentration is } \\
0.015 \mathrm{~g}-\mathrm{Al} / \mathrm{g} \text {-solids, the PO } 4 \text { concentration is } 0.069 \mathrm{~g} \text {-PO } 4 / \mathrm{g} \text {-solids, } \\
\text { and the iron concentration is } 0.010 \mathrm{~g}-\mathrm{Fe} / \mathrm{g} \text {-solids. These high } \\
\text { concentrations only offer weak support of this unusual and non- } \\
\text { typical mineral phase. }\end{array}$ \\
\hline Gibbsite & $\mathrm{Al}(\mathrm{OH})_{3}$ & T-107 & $\begin{array}{l}1 \mathrm{C} \text { (primary) and CW (secondary) sludge } \\
\text { solids. }\end{array}$ & $\begin{array}{l}\text { From PNNL-13394. Study undertaken to characterize solid phases } \\
\text { to understand better the enhanced sludge washing (ESW) and } \\
\text { leaching of Hanford material, to support waste treatment. Identified } \\
\text { by XRD. According to the BBI database, the aluminum solids } \\
\text { concentration is } 0.015 \mathrm{~g}-\mathrm{A} \mathrm{l} / \mathrm{g} \text {-solids (for } 1 \mathrm{C} \text { waste type). This } \\
\text { supports the high abundance of this phase. }\end{array}$ \\
\hline
\end{tabular}


Table 1-1. Crystalline phases identified in Hanford tank waste samples. (56 pages)

\begin{tabular}{|c|c|c|c|c|}
\hline Mineral & $\begin{array}{l}\text { Chemical } \\
\text { Formula }\end{array}$ & Tank & Waste Type & Comments \\
\hline \multirow[t]{2}{*}{$\begin{array}{l}\text { Sodium nitrate } \\
\text { sulfate }\end{array}$} & $\mathrm{Na}_{3} \mathrm{NO}_{3} \mathrm{SO}_{4}$ & TX-113 & $\begin{array}{l}\text { From Best Basis Inventory must be } \mathrm{T} 2 \\
\text { saltcake and/or 1C sludge particulates. }\end{array}$ & $\begin{array}{l}\text { From HNF-13805. } \\
\text { Both simulant formed sodium nitrate sulfate solid particulates and } \\
\text { those obtained from tank TX-113 have been compared. No } \\
\text { additional corroboration, say from SEM-EDS or XRD was } \\
\text { mentioned. This report was an American Chemical Society } \\
\text { presentation so little experimental detail was given. }\end{array}$ \\
\hline & & & T2-saltcake. Direct sampling of solids. & $\begin{array}{l}\text { From HNF-11585. Purpose of study was to measure physical and } \\
\text { chemical data for support of Hanford waste retrieval and } \\
\text { remediation. Purpose of study was to measure physical and } \\
\text { chemical data for support of Hanford waste retrieval and } \\
\text { remediation. The reference used XRD and PLM to identify solids in } \\
\text { dissolved saltcake sample. According to the BBI database, the T2 } \\
\text { waste type contains both high sulfate at } 0.0080 \mathrm{~g} \text {-SO } 4 / \mathrm{g} \text {-solids and } \\
\text { high nitrate at } 0.15 \mathrm{~g}-\mathrm{NO} 3 / \mathrm{g} \text {-solids, consistent with the presence of } \\
\text { this phase. }\end{array}$ \\
\hline
\end{tabular}


Table 1-1. Crystalline phases identified in Hanford tank waste samples. (56 pages)

\begin{tabular}{|c|c|c|c|c|}
\hline Mineral & $\begin{array}{l}\text { Chemical } \\
\text { Formula }\end{array}$ & Tank & Waste Type & Comments \\
\hline $\begin{array}{l}\text { Sodium } \\
\text { fluoride } \\
\text { phosphate }\end{array}$ & $\begin{array}{l}\mathrm{Na}_{7} \mathrm{~F}\left(\mathrm{PO}_{4}\right)_{2}- \\
19 \mathrm{H}_{2} \mathrm{O}\end{array}$ & U-107 & S2 and/or T2 saltcake. & $\begin{array}{l}\text { From HNF-11585. Purpose of study was to measure physical and } \\
\text { chemical data for support of Hanford waste retrieval and } \\
\text { remediation. The reference used polarized light microscopy (PLM) } \\
\text { and XRD to identify this phase in the dissolved saltcake sample. } \\
\text { PLM showed isotropic crystals. Identification based on comparison } \\
\text { between standard and a } 50-50 \text { ( } \mathrm{v} / \mathrm{v} \text { ) waste mix of BY-109 and U-107 } \\
\text { samples. Obtained from evaporation of water-dissolved saltcake } \\
\text { material. According to the BBI database, the T2 waste type possess } \\
0.0027 \mathrm{~g}-\mathrm{F} / \mathrm{g} \text {-solids and } 0.014 \mathrm{~g}-\mathrm{PO} 4 / \mathrm{g} \text {-solids, sufficient for this } \\
\text { mineral to be present in dissolved saltcake material. }\end{array}$ \\
\hline $\begin{array}{l}\text { Sodium } \\
\text { fluoride sulfate }\end{array}$ & $\mathrm{Na}_{3} \mathrm{FSO}_{4}$ & U-107 & $\mathrm{S} 2$ and/or T2 saltcake. & $\begin{array}{l}\text { From HNF-11585. Purpose of study was to measure physical and } \\
\text { chemical data for support of Hanford waste retrieval and } \\
\text { remediation. The reference used polarized light microscopy (PLM) } \\
\text { and XRD to identify this phase. PLM showed isotropic crystals. } \\
\text { Identification based on comparison between standard and a } 50-50 \\
\text { (v/v) waste mix of BY- } 109 \text { and U- } 107 \text { samples. Obtained from } \\
\text { evaporation of water-dissolved saltcake material. According to the } \\
\text { BBI database, the T2 waste type possess } 0.0027 \mathrm{~g}-\mathrm{F} / \mathrm{g} \text {-solids and } \\
0.015 \mathrm{~g} \text {-SO } 4 \mathrm{~g} \text {-solids, sufficient for this mineral to be present in } \\
\text { dissolved saltcake material. }\end{array}$ \\
\hline Aluminosilicate & Al-Si-O solids & U-110 & $\begin{array}{l}\text { Sludge solids. Waste types are } 1 \mathrm{C} \\
\text { (primary) and CW (secondary). }\end{array}$ & $\begin{array}{l}\text { From PNNL-13394. Study undertaken to characterize solid phases to } \\
\text { understand better the enhanced sludge washing (ESW) and leaching } \\
\text { of Hanford material, to support waste treatment. Identified by SEM- } \\
\text { EDS and XRD. Seen in direct-sampled, leached, material. } \\
\text { According to the BBI database, the solids concentrations are } 0.015 \\
\text { g-Al/g-solids and } 0.0062 \mathrm{~g}-\mathrm{Si} / \mathrm{g} \text {-solids. These concentrations are } \\
\text { sufficient for minor abundances of aluminosilicates to be present. }\end{array}$ \\
\hline
\end{tabular}




\subsection{Group 1-8 Solid Sample Waste Type Mineralogy}

To date there are nine WTP-PNNL reports issued that summarize mineralogical phase of actual waste used in various investigations. These reports identify eight groups of composite samples collected from multiple tanks for each group. Information in these reports included a solids characterization to support caustic and oxidative leaching, and water washing of waste. These investigations warrant a separate table from Table 1-1 because there are eight groups of solid waste that were studied that did not have its origin a single tank. Each of these groups was a composite of solids from several Hanford tanks of the same waste type. The minerals identified are listed in Table 2-1 below. 
Table 2-1. A summary of Waste Treatment and Immobilization Plant Pacific Northwest National Laboratory (WTP-PNNL) studies involving Hanford actual waste solid material. (5 pages)

\begin{tabular}{|c|c|c|c|}
\hline Mineral & $\begin{array}{l}\text { Chemical } \\
\text { Formula }\end{array}$ & Tank / Report & Experimental Techniques and Waste Type Discussion \\
\hline Boehmite & $\mathrm{AlOOH}$ & $\begin{array}{l}\text { REDOX (sludge) / } \\
\text { PNNL-17368 (Group 5) }\end{array}$ & $\begin{array}{l}\text { Experimental techniques used include micro-imaging SEM, TEM, XRD, } \\
\text { and EELS. } \\
\text { Grouping includes sludge from following tanks: S-101, S-107, S-110, } \\
\text { SX-103. }\end{array}$ \\
\hline Gibbsite & $\mathrm{Al}(\mathrm{OH})_{3}$ & & \\
\hline Zeolite & Al-Si-O & & \\
\hline Cancrinite & $\mathrm{Na}-\mathrm{Al}-\mathrm{Si}-\mathrm{NO}_{3}-\mathrm{H}_{2} \mathrm{O}$ & & \\
\hline Sodium uranium oxide & $\mathrm{Na}_{2} \mathrm{U}_{2} \mathrm{O}_{7}$ & & \\
\hline Gibbsite & $\mathrm{Al}(\mathrm{OH})_{3}$ & $\begin{array}{l}\text { REDOX (saltcake)/ } \\
\text { PNNL-17368 (Group 6) }\end{array}$ & $\begin{array}{l}\text { Experimental techniques used include micro-imaging SEM, TEM, XRD, } \\
\text { and EELS. } \\
\text { Grouping includes saltcake from following tanks: S-101, S-103, S-105, } \\
\text { S-106, S-108, S-109, S-110, S-111, S-112, SX-102, SX-105, SX-106, } \\
\text { SY-101, SY-103, U-103, U-106, U-108, U-109, U-111. }\end{array}$ \\
\hline Boehmite & $\mathrm{AlOOH}$ & & \\
\hline Sodium oxalate & $\mathrm{Na}_{2} \mathrm{C}_{2} \mathrm{O}_{4}$ & & \\
\hline Cancrinite & $\mathrm{Na}-\mathrm{Al}-\mathrm{Si}-\mathrm{NO}_{3}-\mathrm{H}_{2} \mathrm{O}$ & & \\
\hline Silicon dioxide & $\mathrm{SiO}_{2}$ & & \\
\hline Sodium uranium oxide & $\mathrm{Na}_{2} \mathrm{U}_{2} \mathrm{O}_{7}$ & & \\
\hline
\end{tabular}


Table 2-1. A summary of Waste Treatment and Immobilization Plant Pacific Northwest National Laboratory (WTP-PNNL) studies involving Hanford actual waste solid material. (5 pages)

\begin{tabular}{|c|c|c|c|}
\hline Mineral & $\begin{array}{l}\text { Chemical } \\
\text { Formula }\end{array}$ & Tank / Report & Experimental Techniques and Waste Type Discussion \\
\hline Chromium oxide & $\mathrm{Cr}_{2} \mathrm{O}_{3}$ & & \\
\hline Nitratine & NaNO3 & $\begin{array}{l}\text { Bismuth Phosphate sludge } \\
\text { / PNNL-17992 (Group 1) }\end{array}$ & $\begin{array}{l}\text { Experimental techniques used include micro-imaging SEM, TEM, XRD, } \\
\text { and EELS. 1C and 2C bismuth phosphate waste types. } \\
\text { Grouping includes saltcake from following tanks: B-105, B-110, B-112, } \\
\text { BX-107, BX-111, BX-112, C-108, C-110, T-104, T-108, T-110, TX-109, } \\
\text { TX-110, TX-111, TX-113, TX-114. Only those minerals listed as } \\
\text { Excellent, Good, or Probable are given. }\end{array}$ \\
\hline $\begin{array}{l}\text { Ammonium aluminum } \\
\text { hydrogen phosphate }\end{array}$ & $\mathrm{NH}_{4} \mathrm{AlHP}_{3} \mathrm{O}_{10}$ & & \\
\hline Calcium sulfate & $\mathrm{Ca}\left(\mathrm{SO}_{4}\right)\left(\mathrm{H}_{2} \mathrm{O}\right)_{2}$ & & \\
\hline Bismuth phosphate & $\mathrm{BiPO}_{4}$ & & \\
\hline Gibbsite & $\mathrm{Al}(\mathrm{OH})_{3}$ & $\begin{array}{l}\text { Bismuth Phosphate saltcake } \\
\text { / PNNL-17992 (Group 2) }\end{array}$ & $\begin{array}{l}\text { Experimental techniques used include micro-imaging SEM, TEM, XRD, } \\
\text { and EELS. A, B, BY, R, S, and T bismuth phosphate saltcake waste } \\
\text { types. } \\
\text { Grouping includes saltcake from following tanks: BX-110, BX-111, BY- } \\
\text { 104, BY-105, BY-107, BY-108, BY-109, BY-110, BY-112, T-108, T- } \\
\text { 109, TX-104, TX-113. }\end{array}$ \\
\hline Nitrate Cancrinite & $\begin{array}{l}\mathrm{Na}_{7.92}\left(\mathrm{AlSiO}_{4}\right)_{6} \\
\left(\mathrm{NO}_{3}\right)_{1.7}\left(\mathrm{H}_{2} \mathrm{O}\right)_{2.34}\end{array}$ & & \\
\hline Urancalcarite & $\begin{array}{l}\mathrm{Ca}\left(\mathrm{UO}_{2}\right)_{3} \mathrm{CO}_{3} \\
(\mathrm{OH})\left(\mathrm{H}_{2} \mathrm{O}\right)_{3}\end{array}$ & & \\
\hline
\end{tabular}


Table 2-1. A summary of Waste Treatment and Immobilization Plant Pacific Northwest National Laboratory (WTP-PNNL) studies involving Hanford actual waste solid material. (5 pages)

\begin{tabular}{|c|c|c|c|}
\hline Mineral & $\begin{array}{l}\text { Chemical } \\
\text { Formula }\end{array}$ & Tank / Report & Experimental Techniques and Waste Type Discussion \\
\hline Dorfmanite & $\mathrm{Na}_{2} \mathrm{HPO}_{4}\left(\mathrm{H}_{2} \mathrm{O}\right)_{2}$ & & \\
\hline Gibbsite & $\mathrm{Al}(\mathrm{OH})_{3}$ & $\begin{array}{l}\text { PUREX cladding waste sludge/ } \\
\text { PNNL-18054 (Group 3) }\end{array}$ & $\begin{array}{l}\text { Experimental techniques used include micro-imaging SEM, TEM, XRD, } \\
\text { and EELS. CWP sludge waste type. } \\
\text { Grouping includes saltcake from following tanks with percentages given: } \\
\text { BY-109(51\%), B-108(11\%), C-105(14\%), B-109(11\%), C-103(3\%), C- } \\
104(10 \%) \text {. }\end{array}$ \\
\hline Iron oxide & $\mathrm{Fe}_{1.67} \mathrm{H}_{0.99} \mathrm{O}_{3}$ & & \\
\hline $\begin{array}{l}\text { Nitrate Cancrinite and/or } \\
\text { Hydroxycancrinite }\end{array}$ & $\begin{array}{l}\mathrm{Na}_{8.16}\left(\mathrm{Al}_{6} \mathrm{Si}_{6} \mathrm{O}_{24}\right) \\
\left(\mathrm{NO}_{3}\right)_{2.16}\left(\mathrm{H}_{2} \mathrm{O}\right)_{1.62}, \\
1.06 \mathrm{Na}_{2} \mathrm{O} \cdot \mathrm{Al}_{2} \mathrm{O}_{3} . \\
1.60 \mathrm{SiO}_{2} \cdot 1.60 \mathrm{H}_{2} \mathrm{O}\end{array}$ & & \\
\hline Gibbsite & $\mathrm{Al}(\mathrm{OH})_{3}$ & $\begin{array}{l}\text { REDOX cladding waste sludge/ PNNL- } \\
18054 \text { (Group 4) }\end{array}$ & $\begin{array}{l}\text { Experimental techniques used include micro-imaging SEM, TEM, XRD, } \\
\text { and EELS. CWR sludge waste type. } \\
\text { Grouping includes saltcake from following tanks with percentages given: } \\
\text { U-202(32\%),U-204(17\%), U-203(4\%), U-105(34\%), U-201(3\%). }\end{array}$ \\
\hline $\begin{array}{l}\text { Sodium aluminum silicate } \\
\text { hydrate }\end{array}$ & $\begin{array}{l}\left(\mathrm{Na}_{2} \mathrm{O}\right)_{1.31} \mathrm{Al}_{2} \mathrm{O}_{3} \\
\left(\mathrm{SiO}_{2}\right)_{2.01}\left(\mathrm{H}_{2} \mathrm{O}\right)_{1.65}\end{array}$ & & \\
\hline Boehmite & $\mathrm{AlOOH}$ & & \\
\hline
\end{tabular}


Table 2-1. A summary of Waste Treatment and Immobilization Plant Pacific Northwest National Laboratory (WTP-PNNL) studies involving Hanford actual waste solid material. (5 pages)

\begin{tabular}{|c|c|c|c|}
\hline Mineral & $\begin{array}{l}\text { Chemical } \\
\text { Formula }\end{array}$ & Tank / Report & Experimental Techniques and Waste Type Discussion \\
\hline Zeolite & $\begin{array}{l}\mathrm{NaAlSiO}_{4} \\
\left(\mathrm{H}_{2} \mathrm{O}\right)_{1.1}\end{array}$ & $\begin{array}{l}\text { TBP waste composite } \\
\text { / PNNL-18119 (Group 7) }\end{array}$ & $\begin{array}{l}\text { Experimental techniques used include micro-imaging SEM, TEM, XRD, } \\
\text { and EELS. TBP sludge waste type. Major components include } \\
\text { phosphate, aluminum, sulfate, and iron. } \\
\text { Grouping includes saltcake from following tanks BX-109 (primary) and } \\
\text { B-106 (minor). }\end{array}$ \\
\hline Threadgoldite & $\begin{array}{l}\mathrm{Al}\left(\mathrm{UO}_{2}\right)_{2}\left(\mathrm{PO}_{4}\right)_{2} \\
(\mathrm{OH})\left(\mathrm{H}_{2} \mathrm{O}\right)_{8}\end{array}$ & & \\
\hline Sodium Iron Phosphate & $\mathrm{Na}_{7}\left(\mathrm{FeP}_{2} \mathrm{O}_{7}\right)_{4} \mathrm{PO}_{4}$ & & \\
\hline Lepidocrocite & $\mathrm{FeO}(\mathrm{OH})$ & & \\
\hline Humboldtine & $\mathrm{C}_{2} \mathrm{FeO}_{4} \cdot 2 \mathrm{H}_{2} \mathrm{O}$ & & \\
\hline Iron (III) phosphate oxide & $\mathrm{Fe}_{2} \mathrm{PO}_{5}$ & & \\
\hline $\begin{array}{l}\text { Dioxouranium(VI) } \\
\text { bis(dihydrogenphosphate(I)) } \\
\text { hydrate }\end{array}$ & $\begin{array}{l}\left(\mathrm{UO}_{2}\right)\left(\mathrm{H}_{2} \mathrm{PO}_{2}\right)_{2} \\
\left(\mathrm{H}_{2} \mathrm{O}\right)\end{array}$ & & \\
\hline Sodium Uranyl Phosphate & $\mathrm{Na}_{6}\left(\mathrm{UO}_{2}\right)_{2}\left(\mathrm{PO}_{4}\right)_{4}$ & & \\
\hline Gibbsite & $\mathrm{Al}(\mathrm{OH})_{3}$ & & \\
\hline
\end{tabular}


Table 2-1. A summary of Waste Treatment and Immobilization Plant Pacific Northwest National Laboratory (WTP-PNNL) studies involving Hanford actual waste solid material. (5 pages)

\begin{tabular}{|c|c|c|c|}
\hline Mineral & $\begin{array}{l}\text { Chemical } \\
\text { Formula }\end{array}$ & Tank / Report & Experimental Techniques and Waste Type Discussion \\
\hline Gibbsite & $\mathrm{Al}(\mathrm{OH})_{3}$ & $\begin{array}{l}\text { Ferrocynide (FeCN) waste } \\
\text { / PNNL-18120 (Group 8) }\end{array}$ & $\begin{array}{l}\text { Experimental techniques used include micro-imaging SEM, TEM, XRD, } \\
\text { and EELS. } 1 \mathrm{FeCN}, \mathrm{PFeCN} \text {, and TFeCN composite waste type. } \\
\text { Grouping includes sample include contributions from following tanks } \\
\text { BY-110 (major), BY-108, BY-105, BY-104 (minor), BY-106 (minor), } \\
\text { plus lesser contributions from other tanks. }\end{array}$ \\
\hline Sodium uranium oxide & $\mathrm{Na}_{2} \mathrm{U}_{2} \mathrm{O}_{7}$ & & \\
\hline Hematite & $\mathrm{Fe}_{2} \mathrm{O}_{3}$ & & \\
\hline $\begin{array}{l}\text { Strontium Hydrogen } \\
\text { Phosphite }\end{array}$ & $\mathrm{Sr}\left(\mathrm{H}_{2} \mathrm{PO}_{3}\right)_{2}$ & & \\
\hline Hydroxycancrinite & $\begin{array}{l}1.06 \mathrm{Na}_{2} \mathrm{O} \cdot \mathrm{Al}_{2} \mathrm{O}_{3} \cdot \\
1.60 \mathrm{SiO}_{2} \cdot \\
1.60 \mathrm{H}_{2} \mathrm{O}\end{array}$ & & \\
\hline Bassanite & $\begin{array}{l}\mathrm{Ca}\left(\mathrm{SO}_{4}\right)\left(\mathrm{H}_{2} \mathrm{O}\right)_{0.5} \\
\text { (minor phase) }\end{array}$ & & \\
\hline Sodium Oxide Cyanide & $\mathrm{Na}_{3}(\mathrm{CN}) \mathrm{O}$ & & \\
\hline $\begin{array}{l}\text { Sodium Uranyl } \\
\text { Carbonate }\end{array}$ & $\begin{array}{l}\mathrm{Na}_{4}\left(\mathrm{UO}_{2}\right)\left(\mathrm{CO}_{3}\right)_{3} \\
\text { (minor phase) }\end{array}$ & & \\
\hline
\end{tabular}




\subsection{Boil-down Solid Phase Identification in Hanford Tank Samples}

A common Hanford Tank practice uses tank samples, heats them at sub-ambient temperature and pressure, causes evaporation, and initiates solids precipitation. The results are then used to estimate the end point of so-called evaporation campaigns used in tank management by liquid phase reduction. The resulting slurry or solids are cooled to ambient temperature. This practice concentrates the non-volatile material present and reduces the total amount of waste present, via water removal. The rationale for this processing is waste volume minimization. Table 3-1 below lists solids identified from these laboratory (i.e., small scale) studies. The waste type group is not listed here as the solids formed originated from supernate (e.g., the liquid fraction).

An interesting comparison that can be made, on a tank-specific basis, is that for direct saltcake sampling (Table 1) to boil-down solids production in this section (Table 3). Unfortunately, only one comparison can be made, and this corresponds to tank AP-105. In particular, the fluoridecontaining solids for this tank reveals that the saltcake contains the phase of $\mathrm{Na}_{3} \mathrm{FSO}_{4}$, whereas the $\mathrm{Na}_{7} \mathrm{~F}\left(\mathrm{PO}_{4}\right)_{2}-19 \mathrm{H}_{2} \mathrm{O}$ crystalline phase was identified in the boil-down solid sample. There was no mention of $\mathrm{Na}_{3} \mathrm{FSO}_{4}$ in the boildown referenced report. From this it can be concluded that other differences must exist between the two precipitated solid materials to account for the discrepancy.

A second comparison that can be made is between observed crystal phases from direct sampling (with caustic treatment in some instances) of section 1, Table 1-1, results with the boildown results of Table 3-1 here. All observed boildown phases were observed as part of the saltcake minerals of Table 1-1, with the exception of sodium nitrite. Examples include cancrinite, sodium oxalate, sodium fluoride phosphate, sodium carbonate, and sodium fluoride sulfate. 
Table 3-1. The characteristics of Hanford tank boil-down laboratory studies. (4 pages)

\begin{tabular}{|c|c|c|c|c|}
\hline Mineral & Chemical Formula & Tank & Waste Type & Comments \\
\hline Cancrinite & $\mathrm{Na}_{6} \mathrm{Ca}_{1.5} \mathrm{Al}_{6} \mathrm{Si}_{6} \mathrm{O}_{24}\left(\mathrm{CO}_{3}\right)_{1.6}$ & AP-101 & Boil-down from supernatant liquid. & $\begin{array}{l}\text { From 7S110-RWW-04-029. Identification } \\
\text { techniques in report include PLM, SEM-EDS, } \\
\text { and XRD. Here identified by chemical } \\
\text { composition and morphology. }\end{array}$ \\
\hline Sodium oxalate & $\mathrm{Na}_{2} \mathrm{C}_{2} \mathrm{O}_{4}$ & AP-101 & Boil-down from supernatant liquid. & $\begin{array}{l}\text { From 7S110-RWW-04-029. Identification } \\
\text { techniques include PLM, SEM-EDS, and } \\
\text { XRD. }\end{array}$ \\
\hline $\begin{array}{l}\text { Sodium fluoride } \\
\text { phosphate hydrate }\end{array}$ & $\mathrm{Na}_{7} \mathrm{~F}\left(\mathrm{PO}_{4}\right)_{2}-19 \mathrm{H}_{2} \mathrm{O}$ & AP-101 & $\begin{array}{l}\text { Boil-down from supernatant liquid, resulting in solids } \\
\text { precipitation. }\end{array}$ & $\begin{array}{l}\text { From } 7 \text { S110-WSC-08-145. Identification } \\
\text { techniques are PLM, SEM-EDS, and XRD. } \\
\text { Composition ca. } 90 \text { wt. } \% \text {. }\end{array}$ \\
\hline Sodium oxalate & $\mathrm{Na}_{2} \mathrm{C}_{2} \mathrm{O}_{4}$ & AP-101 & $\begin{array}{l}\text { Boil-down from supernatant liquid, resulting in solids } \\
\text { precipitation. }\end{array}$ & $\begin{array}{l}\text { From 7S110-WSC-08-145. Identification } \\
\text { techniques are PLM, SEM-EDS, and XRD. } \\
\text { Composition ca. } 9 \text { wt. } \% \text {. }\end{array}$ \\
\hline Sodium nitrate & $\mathrm{NaNO}_{3}$ & AP-101 & $\begin{array}{l}\text { Boil-down from supernatant liquid, resulting in solids } \\
\text { precipitation }\end{array}$ & $\begin{array}{l}\text { From 7S110-WSC-08-145. Identification } \\
\text { techniques are PLM, SEM-EDS, and XRD. } \\
\text { Composition ca. } 75 \text { wt. } \% \text {. }\end{array}$ \\
\hline $\begin{array}{l}\text { Sodium carbonate } \\
\text { hydrate }\end{array}$ & $\mathrm{Na}_{2} \mathrm{CO}_{3}-\mathrm{H}_{2} \mathrm{O}$ & AP-101 & $\begin{array}{l}\text { Boil-down from supernatant liquid, resulting in solids } \\
\text { precipitation. }\end{array}$ & $\begin{array}{l}\text { From 7S110-WSC-08-145. Identification } \\
\text { techniques are PLM, SEM-EDS, and XRD. } \\
\text { Composition ca. } 10 \text { wt. } \% \text {. }\end{array}$ \\
\hline Sodium nitrite & $\mathrm{NaNO}_{2}$ & AP-104 & Precipitated supernate from evaporator boil-down study. & $\begin{array}{l}\text { From 7S110-DBB-03-013. Use of polarized } \\
\text { light microscopy (PLM), SEM-EDS, and } \\
\text { XRD was used to confirm crystal type. A } \\
\text { major constituent. }\end{array}$ \\
\hline
\end{tabular}


Table 3-1. The characteristics of Hanford tank boil-down laboratory studies. (4 pages)

\begin{tabular}{|c|c|c|c|c|}
\hline Mineral & Chemical Formula & Tank & Waste Type & Comments \\
\hline Sodium nitrate & $\mathrm{NaNO}_{3}$ & AP-104 & Precipitated supernate from evaporator boil-down study. & $\begin{array}{l}\text { From 7S110-DBB-03-013. Use of polarized } \\
\text { light microscopy (PLM), SEM-EDS, and } \\
\text { XRD was used to confirm crystal type. A } \\
\text { major constituent. }\end{array}$ \\
\hline Sodium oxalate & $\mathrm{Na}_{2} \mathrm{C}_{2} \mathrm{O}_{4}$ & AP-104 & Precipitated supernate from evaporator boil-down study. & $\begin{array}{l}\text { From 7S110-DBB-03-013. Use of polarized } \\
\text { light microscopy (PLM), SEM-EDS, and } \\
\text { XRD was used to confirm crystal type. A } \\
\text { major constituent. }\end{array}$ \\
\hline $\begin{array}{l}\text { Sodium carbonate } \\
\text { monohydrate }\end{array}$ & $\mathrm{Na}_{2} \mathrm{CO}_{3}-\mathrm{H}_{2} \mathrm{O}$ & AP-104 & Precipitated supernate from evaporator boil-down study. & $\begin{array}{l}\text { From 7S110-DBB-03-013. Use of polarized } \\
\text { light microscopy (PLM), SEM-EDS, and } \\
\text { XRD was used to confirm crystal type. A } \\
\text { major constituent. }\end{array}$ \\
\hline $\begin{array}{l}\text { Sodium fluoride } \\
\text { phosphate hydrate }\end{array}$ & $\mathrm{Na}_{7} \mathrm{~F}\left(\mathrm{PO}_{4}\right)_{2}-19 \mathrm{H}_{2} \mathrm{O}$ & AP-104 & Precipitated supernate from evaporator boil-down study. & $\begin{array}{l}\text { From 7S110-DBB-03-013. Use of polarized } \\
\text { light microscopy (PLM), SEM-EDS, and } \\
\text { XRD was used to confirm crystal type. A } \\
\text { major constituent. }\end{array}$ \\
\hline $\begin{array}{l}\text { Sodium phosphate } \\
\text { dodecahydrate }\end{array}$ & $\mathrm{Na}_{3} \mathrm{PO}_{4}-12 \mathrm{H}_{2} \mathrm{O}$ & AP-104 & Precipitated supernate from evaporator boil-down study. & $\begin{array}{l}\text { From 7S110-DBB-03-013. Use of polarized } \\
\text { light microscopy (PLM), SEM-EDS, and } \\
\text { XRD was used to confirm crystal type. A } \\
\text { major constituent. }\end{array}$ \\
\hline Sodium nitrate & $\mathrm{NaNO}_{3}$ & AP-105 & $\begin{array}{l}\text { Boildown of supernatant liquid, resulting in precipitation of } \\
\text { solids. }\end{array}$ & $\begin{array}{l}\text { From 7S110-WSC-07-143. Determined from } \\
\text { XRD, SEM-EDS, and PLM. Approximately } \\
49 \mathrm{wt} \% \text { abundance. }\end{array}$ \\
\hline $\begin{array}{l}\text { Sodium fluoride } \\
\text { phosphate hydrate }\end{array}$ & $\mathrm{Na}_{7} \mathrm{~F}\left(\mathrm{PO}_{4}\right)_{2}-19 \mathrm{H}_{2} \mathrm{O}$ & AP-105 & $\begin{array}{l}\text { Boildown of supernatant liquid, resulting in precipitation of } \\
\text { solids. }\end{array}$ & $\begin{array}{l}\text { From 7S110-WSC-07-143. Determined from } \\
\text { XRD, SEM-EDS, and PLM. Approximately } \\
49 \text { wt. } \% \text { abundance. }\end{array}$ \\
\hline
\end{tabular}


Table 3-1. The characteristics of Hanford tank boil-down laboratory studies. (4 pages)

\begin{tabular}{|c|c|c|c|c|}
\hline Mineral & Chemical Formula & Tank & Waste Type & Comments \\
\hline $\begin{array}{l}\text { Sodium fluoride } \\
\text { sulfate }\end{array}$ & $\mathrm{Na}_{3} \mathrm{FSO}_{4}$ & AP-105 & $\begin{array}{l}\text { Evaporated boildown of the supernate resulting in solids } \\
\text { precipitation. }\end{array}$ & $\begin{array}{l}\text { From 7S110-GAC-06-064. PLM morphology } \\
\text { and SEM-EDS used to identify crystal type. } \\
\text { Treated liquid sample is the boildown } \\
\text { liquid supernate. This study was to help } \\
\text { identify the unexpected solids formation a } \\
\text { year after the boildown of tank AP-108 ( } 63 \\
\text { inches of new solids). }\end{array}$ \\
\hline Sodium oxalate & $\mathrm{Na}_{2} \mathrm{C}_{2} \mathrm{O}_{4}$ & AP-105 & $\begin{array}{l}\text { Boildown of supernatant liquid, resulting in precipitation of } \\
\text { solids. }\end{array}$ & $\begin{array}{l}\text { From } 7 \mathrm{~S} 110-W S C-07-143 \text {. Determined as a } \\
\text { trace constituent from SEM-EDS, and PLM. } \\
\text { Approximately } 2 \text { wt. } \% \text { abundance. }\end{array}$ \\
\hline $\begin{array}{l}\text { Sodium carbonate } \\
\text { hydrate }\end{array}$ & $\mathrm{Na}_{2} \mathrm{CO}_{3}-\mathrm{H}_{2} \mathrm{O}$ & AP-105 & $\begin{array}{l}\text { Boildown of supernatant liquid, resulting in precipitation of } \\
\text { solids. }\end{array}$ & $\begin{array}{l}\text { From } 7 \mathrm{~S} 110-\mathrm{WSC}-07-143 \text {. Determined as a } \\
\text { trace constituent from SEM-EDS, and PLM. } \\
\text { Approximately } 8 \text { wt.\% abundance. }\end{array}$ \\
\hline $\begin{array}{l}\text { Sodium fluoride } \\
\text { phosphate }\end{array}$ & $\mathrm{Na}_{7} \mathrm{~F}\left(\mathrm{PO}_{4}\right)_{2}-19 \mathrm{H}_{2} \mathrm{O}$ & AP-107 & $\begin{array}{l}\text { Evaporated supernatant resulting in solids precipitation (i.e., } \\
\text { boildown study). }\end{array}$ & $\begin{array}{l}\text { From 7S110-GAC-06-064. Work supported } \\
\text { evaporator campaign. PLM (for morphology) } \\
\text { and SEM-EDS used to identify crystal } \\
\text { composition. Waste template inventories of } \\
\text { phosphate and fluoride showed only dilute } \\
\text { concentrations of both prior to boildown of } \\
\text { waste. Post boildown crystals were needle } \\
\text { like. The needle crystals were cemented } \\
\text { together by sodium carbonate solid. }\end{array}$ \\
\hline $\begin{array}{l}\text { Thenardite, Sodium } \\
\text { Carbonate } \\
\text { monohydrate }\end{array}$ & $\mathrm{Na}_{2} \mathrm{CO}_{3}-\mathrm{H}_{2} \mathrm{O}$ & AP-108 & $\begin{array}{l}\text { Supernate boil-down. A salt cake that precipitated when } \\
\text { evaporator concentrate was put into tank. Taken by grab } \\
\text { sample. }\end{array}$ & $\begin{array}{l}\text { From } 7 \text { S110-GAC-06-058. Identified by both } \\
\text { XRD and Optical Microscopy (PLM). } \\
\text { Comprised }>90 \text { wt. \% of solids. }\end{array}$ \\
\hline
\end{tabular}


Table 3-1. The characteristics of Hanford tank boil-down laboratory studies. (4 pages)

\begin{tabular}{|l|l|l|l|l|}
\hline Mineral & Chemical Formula & Tank & Waste Type & Comments \\
\hline $\begin{array}{l}\text { Sodium Fluoride } \\
\text { Phosphate }\end{array}$ & $\mathrm{Na}_{7} \mathrm{~F}\left(\mathrm{PO}_{4}\right)_{2}-19 \mathrm{H}_{2} \mathrm{O}$ & AP-108 & $\begin{array}{l}\text { Supernate boil-down. A salt cake precipitated when } \\
\text { evaporator concentrate was put into tank. }\end{array}$ & $\begin{array}{l}\text { From 7S110-GAC-06-058. Trace amounts } \\
\text { seen by Optical Microscopy, not confirmed } \\
\text { by XRD because the quantity was too small. } \\
\text { Comprised }<10 \text { wt.\% solids. }\end{array}$ \\
\hline Sodium Oxalate & $\mathrm{Na}_{2} \mathrm{C}_{2} \mathrm{O}_{4}$ & AP-108 & $\begin{array}{l}\text { Supernate boil-down. A salt cake precipitated when } \\
\text { evaporator concentrate was put into tank. }\end{array}$ & $\begin{array}{l}\text { From 7S110-GAC-06-058. Very trace } \\
\text { amounts by Optical Microscopy, too trace to } \\
\text { observe by XRD. Comprised much less than } \\
1 \text { wt.\% of solids. }\end{array}$ \\
\hline $\begin{array}{l}\text { Kogarkoite, sodium } \\
\text { fluoride Sulfate }\end{array}$ & $\mathrm{Na}_{3} \mathrm{FSO}_{4}$ & AP-108 & $\begin{array}{l}\text { Supernate boil-down. A salt cake precipitated when } \\
\text { evaporator concentrate was put into tank. }\end{array}$ & $\begin{array}{l}\text { From 7S110-GAC-06-058. Identified By } \\
\text { XRD. Some crystals that could be this phase } \\
\text { were observed by Optical Microscopy. }\end{array}$ \\
\hline
\end{tabular}




\subsection{SEM-EDS Identification in Hanford Tank Samples}

Elemental associations are typically identified by SEM-EDS observation where stoichiometric identification of specific solid crystal phases is not possible. This was included because there are often trace amounts of a phase that cannot be conclusively identified, but the elements in the mineral can be identified. Note that SEM cannot see hydrogen and because oxygen is ubiquitous (e.g., an impurity), many of the minerals that contain oxygen and/or hydrogen can be hydroxides or oxides because SEM cannot distinguish the difference. 
Table 4-1. The elemental composition of various Hanford tank waste samples. (5 pages)

\begin{tabular}{|c|c|c|c|}
\hline Elements in Solid & Tank & Waste Type & Comments \\
\hline $\mathrm{Fe}-\mathrm{O}$ & AN-107 & A2 saltcake & From RPP-20018. SEM-EDS, PLM, EDS analysis. Saltcake solids analysis. \\
\hline $\mathrm{Na}-\mathrm{Al}-\mathrm{Si}$ & AP-105 & $\begin{array}{l}\text { Evaporated supernatant } \\
\text { resulting in solids } \\
\text { precipitation. }\end{array}$ & $\begin{array}{l}\text { From 7S110-GAC-06-064. PLM tentatively identified crystal as sodium aluminum sulfate; } \\
\text { however SEM-EDS used to identify crystal composition as some Al-Si containing material. }\end{array}$ \\
\hline Al-Si-O & AW-105 & CWZr2 sludge solids & From PNNL-13394. Identified by TEM, SEM-EDS and XRD. \\
\hline $\mathrm{Zr}-\mathrm{Fe}-\mathrm{O}$ & AZ-101 & $\begin{array}{l}\text { P3AZ1 washed saltcake } \\
\text { solids. }\end{array}$ & From PNNL report WTP-RPT-076 Rev.0. TEM and EDS used to identify solid phase. \\
\hline Na-Al-Si-O & BY-109 & $\begin{array}{l}\text { Solids remaining after } \\
\text { CWP2 saltcake } \\
\text { dissolution in water. } \\
\text { Likely zeolite. }\end{array}$ & $\begin{array}{l}\text { From 7S110-DLH-06-073. Both PLM (for morphology) and SEM-EDS were used to identify } \\
\text { crystal type. Sodium is found primarily in sodium oxalate and sodium aluminosilicate. }\end{array}$ \\
\hline Al-Si-O & B-111 & $2 \mathrm{C}$ sludge solids. & From PNNL-13394. Identified by SEM-EDS, TEM, and XRD. \\
\hline $\mathrm{Ag}-\mathrm{O}$ & C-103 & $\begin{array}{l}\text { CWP1 sludge (only heel } \\
\text { left over after retrieval) }\end{array}$ & $\begin{array}{l}\text { Ag-O was identified as a phase rich in silver and oxygen with no other elements by SEM in the heel } \\
\text { left over after the sludge in C-103 was sluiced into AN-106. Thus, there is likely Ag-O in the sludge } \\
\text { in AN-106 as well. This mineral was identified in report PNNL-16738. Because there was too little } \\
\text { of this mineral to be observed by SEM, the exact stoichiometry is speculative, and this mineral } \\
\text { could easily by } \mathrm{Ag}(\mathrm{OH}) \text { rather than } \mathrm{Ag} 2-\mathrm{O} \text {, because SEM cannot distinguish between them. This } \\
\text { tank has been sluiced into tank AN-106, so this phase likely also exists in An-106. }\end{array}$ \\
\hline
\end{tabular}


Table 4-1. The elemental composition of various Hanford tank waste samples. (5 pages)

\begin{tabular}{|c|c|c|c|}
\hline Elements in Solid & Tank & Waste Type & Comments \\
\hline$(\mathrm{Ag}, \mathrm{Hg})-\mathrm{O}$ & $\mathrm{C}-103$ & $\begin{array}{l}\text { CWP1 sludge (only heel } \\
\text { left over after retrieval) }\end{array}$ & $\begin{array}{l}\text { Ag-Hg-O solid solution was identified as a phase rich in silver, mercury, and oxygen with no other } \\
\text { elements by SEM in the heel left over after the sludge in C-103 was sluiced into AN-106. Thus, } \\
\text { there is likely Hg-Ag-O in the sludge in AN-106 as well. This mineral was identified in report } \\
\text { PNNL-16738. Because there was too little of this mineral to be observed by XRD, the exact } \\
\text { stoichiometry is speculative, and this mineral could easily by } \mathrm{Ag}(\mathrm{OH}) 2-\mathrm{Hg}(\mathrm{OH}) 2 \text { rather than Ag-O, } \\
\text { because SEM cannot distinguish between them. The waste from this tank has been sluiced into tank } \\
\text { AN-106, so this phase likely also exists in AN-106. The Hg-Ag-O phase was also observed in the } \\
\text { bulk CWP-1 Sludge in C-103 prior to retrieval in report 7S110-DLH-04-015. }\end{array}$ \\
\hline $\mathrm{Zr}-\mathrm{O}$ & C-103 & $\begin{array}{l}\text { CWP1 sludge (only heel } \\
\text { left over after retrieval) }\end{array}$ & $\begin{array}{l}\text { Rarely observed by SEM in PNNL-16738. The bulk of the waste from this tank has been sluiced } \\
\text { into tank AN-106, so this phase likely also exists in AN-106. }\end{array}$ \\
\hline Th-O & C-103 & $\begin{array}{l}\text { CWP1 sludge (only heel } \\
\text { left over after retrieval) }\end{array}$ & $\begin{array}{l}\text { Rarely observed by SEM in PNNL-16738. The bulk of the waste from this tank has been sluiced } \\
\text { into tank AN-106, so this phase likely also exists in AN-106. }\end{array}$ \\
\hline $\mathrm{Fe}-\mathrm{Pb}-\mathrm{O}$ & C-103 & $\begin{array}{l}\text { CWP1 sludge (only heel } \\
\text { left over after retrieval) }\end{array}$ & $\begin{array}{l}\text { Rarely observed by SEM in PNNL-16738. The bulk of the waste from this tank has been sluiced } \\
\text { into tank AN-106, so this phase likely also exists in AN-106. }\end{array}$ \\
\hline Na-Ca-U-O & C-103 & $\begin{array}{l}\text { CWP1 sludge (only heel } \\
\text { left over after retrieval) }\end{array}$ & $\begin{array}{l}\text { Rarely observed by SEM in PNNL-16738. The bulk of the waste from this tank has been sluiced } \\
\text { into tank AN-106, so this phase likely also exists in AN-106. The stoichiometry identified by SEM } \\
\text { is very similar to the known mineral Andersonite }[\mathrm{Na} 2 \mathrm{Ca}(\mathrm{UO} 2)(\mathrm{CO} 3) 3 \cdot 6 \mathrm{H} 2 \mathrm{O}] \text {. This phase grew } \\
\text { on Gibbsite particles. }\end{array}$ \\
\hline $\mathrm{Ca}-\mathrm{P}-\mathrm{O}$ & C-103 & $\begin{array}{l}\text { CWP1 sludge (only heel } \\
\text { left over after retrieval) }\end{array}$ & $\begin{array}{l}\text { Occasionally observed by SEM in PNNL-16738. This phase likely also occurs in the sludge } \\
\text { transferred from C-103 to AN-106. This is likely a calcium phosphate because no other elements } \\
\text { are incorporated into it. However, there are many calcium phosphates, so we cannot concussively } \\
\text { identify them. An email from Ken Krupka indicated that this phase also has } 2-4 \mathrm{Wt} \% \text { fluoride that } \\
\text { was not documented in the report. A reasonable hypothesis for this phase is hydroxyapatite with } \\
\text { fluoride substituted for some of the hydroxyls. This is reasonable because hydroxyapatite and } \\
\text { fluoroapatite are known to form a solid solution series (Lindsay and Others, 1989). This tank has } \\
\text { been sluiced into tank AN-106, so this phase likely also exists in An-106. }\end{array}$ \\
\hline
\end{tabular}


Table 4-1. The elemental composition of various Hanford tank waste samples. (5 pages)

\begin{tabular}{|c|c|c|c|}
\hline Elements in Solid & Tank & Waste Type & Comments \\
\hline Na-Al-Si-O & C-103 & CWP1 sludge & $\begin{array}{l}\text { Identified by SEM in } 7 \mathrm{~S} 110-\mathrm{DLH}-04-015 \text {. The bulk of the waste from this tank has been sluiced } \\
\text { into tank AN-106, so this phase likely also exists in AN-106. }\end{array}$ \\
\hline$(\mathrm{Ag}, \mathrm{Hg})-\mathrm{O}$ & C-103 & $\begin{array}{l}\text { CWP1 sludge (only heel } \\
\text { left over after retrieval) }\end{array}$ & $\begin{array}{l}\text { Ag-Hg-O solid solution was identified as a phase rich in silver, mercury, and oxygen with no other } \\
\text { elements by SEM in the heel left over after the sludge in C-103 was sluiced into AN-106. Thus, } \\
\text { there is likely Hg-Ag-O in the sludge in AN-106 as well. This mineral was identified in report } \\
7 \mathrm{~S} 110-\mathrm{DLH}-04-015 \text { on the bulk sludge prior to retrieval, but has also been identified in PNNL- } \\
16738 \text { in the heel that remains in C-103. Because there was too little of this mineral to be quantified } \\
\text { by Energy Dispersive Spectroscopy (EDS) attached to the SEM, the exact stoichiometry is } \\
\text { speculative, and this mineral could easily by } \mathrm{Ag}(\mathrm{OH}) 2-\mathrm{Hg}(\mathrm{OH}) 2 \text { rather than Ag-O, because SEM } \\
\text { cannot distinguish between them. }\end{array}$ \\
\hline Al-Si-O solids & C-107 & $\begin{array}{l}\text { Waste types: } 1 \mathrm{C} \\
\text { (primary) and } \mathrm{CW} \\
\text { (secondary). }\end{array}$ & $\begin{array}{l}\text { From PNNL-13394. Study undertaken to characterize solid phases to understand better the } \\
\text { enhanced sludge washing (ESW) and leaching of Hanford material, to support waste treatment. } \\
\text { Identified by TEM and XRD. Sludge solids. Seen in both as-received and caustic leached ( } 3 \mathrm{M}) \\
\text { solids. }\end{array}$ \\
\hline Na-Al-P-rich solid & C-107 & $\begin{array}{l}\text { 1C, CWP2, SRR sludge } \\
\text { composite waste type. }\end{array}$ & $\begin{array}{l}\text { From 7S110-JMF-05-015. Caustic demand test as part of corrosion mitigation project. The } \\
\text { techniques of PLM and SEM-EDS were used to identify crystalline solid phases. The } 1 \mathrm{C} \text { waste } \\
\text { type, according to the BBI Template Composition report [RPP- } 8847] \text {, contains very high } \\
\text { concentrations of } \mathrm{Al}(0.015 \mathrm{~g}-\mathrm{Al} / \mathrm{g}) \text { and } \mathrm{PO} 4(0.069 \mathrm{~g}-\mathrm{P} / \mathrm{g}) \text {. A major constituent }(>10 \mathrm{wt} . \%) \text {. }\end{array}$ \\
\hline Si-Al-Na-rich solid & C-107 & $\begin{array}{l}\text { 1C, CWP2, SRR sludge } \\
\text { composite waste type. }\end{array}$ & $\begin{array}{l}\text { From } 7 \mathrm{~S} 110-\mathrm{JMF}-05-015 \text {. Caustic demand test as part of corrosion mitigation project. The } \\
\text { techniques of PLM and SEM-EDS were used to identify crystalline solid phases. The } 1 \mathrm{C} \text { waste } \\
\text { type, according to the BBI Template Composition report [RPP-8847], contains very high } \\
\text { concentrations of } \mathrm{Al}(0.015 \mathrm{~g}-\mathrm{Al} / \mathrm{g}) \text { and } \mathrm{Si}(0.0062 \mathrm{~g}-\mathrm{Si} / \mathrm{g}) \text {. A minor constituent }(1-10 \mathrm{wt} . \%) \text {. }\end{array}$ \\
\hline Na-Al-F-rich solid & $\mathrm{C}-107$ & $\begin{array}{l}\text { 1C, CWP2, SRR sludge } \\
\text { composite waste type. }\end{array}$ & $\begin{array}{l}\text { From 7S110-JMF-05-015. Caustic demand test as part of corrosion mitigation project. The } \\
\text { techniques of PLM and SEM-EDS were used to identify crystalline solid phases. The } 1 \mathrm{C} \text { waste } \\
\text { type, according to the BBI Template Composition report [RPP- } 8847] \text {, contains very high } \\
\text { concentrations of } \mathrm{Al}(0.015 \mathrm{~g}-\mathrm{Al} / \mathrm{g}) \text { and } \mathrm{F}(0.015 \mathrm{~g}-\mathrm{F} / \mathrm{g}) \text {. A minor constituent (1-10 wt.\%). }\end{array}$ \\
\hline
\end{tabular}


Table 4-1. The elemental composition of various Hanford tank waste samples. (5 pages)

\begin{tabular}{|c|c|c|c|}
\hline Elements in Solid & Tank & Waste Type & Comments \\
\hline $\begin{array}{l}\text { Na-Bi-Fe-P-rich sodium } \\
\text { bismuth phosphate } \\
\text { hydroxide }\end{array}$ & C-107 & $\begin{array}{l}\text { 1C, CWP2, SRR sludge } \\
\text { composite waste type. }\end{array}$ & $\begin{array}{l}\text { From 7S110-JMF-05-015. Caustic demand test as part of corrosion mitigation project. The } \\
\text { techniques of PLM and SEM-EDS were used to identify crystalline solid phases. The } 1 \mathrm{C} \text { waste } \\
\text { type, according to the BBI database, contains very high concentrations of } \mathrm{Bi}(0.019 \mathrm{~g}-\mathrm{Bi} / \mathrm{g}), \mathrm{Fe} \\
(0.010 \mathrm{~g}-\mathrm{Fe} / \mathrm{g}) \text { and PO4 }(0.069 \mathrm{~g}-\mathrm{P} / \mathrm{g}) \text {. A major constituent }(>10 \mathrm{wt} . \%) \text {. }\end{array}$ \\
\hline Al-Si-O & S-107 & $\begin{array}{l}\text { Waste types: R (primary) } \\
\text { and EB (secondary). }\end{array}$ & $\begin{array}{l}\text { From PNNL-13394. Study undertaken to characterize solid phases to understand better the } \\
\text { enhanced sludge washing (ESW) and leaching of Hanford material, to support waste treatment. } \\
\text { Identified only through TEM. Sludge solids. Seen in both direct-sampled and caustic leached } \\
\text { (3M) materials. From BBI database, the quantities of aluminum and silicon are } 0.045 \mathrm{~g}-\mathrm{Al} / \mathrm{g} \text {-solid } \\
\text { and } 167 \text { ug-Si/g-solid. As a minor identified component, this is consistent with tank composition. }\end{array}$ \\
\hline $\mathrm{Ca}-\mathrm{Cr}-\mathrm{O}$ & S-112 & $\begin{array}{l}\text { Heel after retrieval of } \\
\text { REDOX Process } \\
\text { Cladding Waste (CWR) } \\
\text { and S Saltcake }\end{array}$ & $\begin{array}{l}\text { Identified by SEM in S-112 Heel samples in PNNL-17593. FH-0202771 simulated the dissolution } \\
\text { of the S Saltcake in S- } 112 \text { and identified minerals in the residuals that did not dissolve. They found } \\
\text { Ca-Al-Cr-O bearing particles, which they thought might be a solid solution of calcium aluminate } \\
\text { and calcium chromite. They (FH-2002771) also identified Ca3Al2(OH)12 by XRD. It is likely that } \\
\text { the particles observed in FH- } 0202771 \text { are agglomerates of calcium aluminate and calcium chromite. } \\
\text { The Ca-Cr-O phase identified in PNNL-17593 is likely calcium chromate that had not agglomerated } \\
\text { with calcium aluminate in the real tank. }\end{array}$ \\
\hline $\begin{array}{l}\text { PB-Cl-(maybe oxygen as } \\
\text { well) }\end{array}$ & S-112 & $\begin{array}{l}\text { Heel after retrieval of } \\
\text { REDOX Process } \\
\text { Cladding Waste (CWR) } \\
\text { and S Saltcake }\end{array}$ & $\begin{array}{l}\text { Rare particles identified in PNNL-17593 by SEM. They could not tell if the oxygen atoms came } \\
\text { from the same particle as the } \mathrm{Pb}-\mathrm{Cl} \text { particles or were from other nearby particles. }\end{array}$ \\
\hline $\mathrm{Fe}-\mathrm{O}$ (maybe Mn) & S-112 & $\begin{array}{l}\text { Heel after retrieval of } \\
\text { REDOX Process } \\
\text { Cladding Waste (CWR) } \\
\text { and S Saltcake }\end{array}$ & $\begin{array}{l}\text { Rare particles identified in PNNL- } 17593 \text { by SEM. There was some Mn associated with the Fe } \\
\text { particles, but it was not clear if the Mn was incorporated into the crystal structure or in the form of } \\
\text { even smaller particles stuck to the Fe surface. }\end{array}$ \\
\hline
\end{tabular}


Table 4-1. The elemental composition of various Hanford tank waste samples. (5 pages)

\begin{tabular}{|l|l|l|l|}
\hline Elements in Solid & Tank & Waste Type & Comments \\
\hline $\begin{array}{l}\text { Na-Al-O, } \\
\text { a silicate }\end{array}$ & S-112 & R1 sludge & $\begin{array}{l}\text { From PNNL-17593. Identified by SEM, so cannot see light elements (such as H) that may be } \\
\text { present. Thermodynamic calculations reported in PNNL-17593 indicated that the solution was near } \\
\text { saturation with dawsonite, so the Na-Al-O phase may be dawsonite. The SEM analysis indicated } \\
\text { that there was more Na in this solid than is typical of dawsonite. }\end{array}$ \\
\hline Al-Si-O & SX-108 & Sludge solids. & From PNNL-13394. Identified only through TEM. \\
\hline Al-O & SY-102 & $\begin{array}{l}\text { Solids waste type, } \\
\text { although not specified, is } \\
\text { likely NA sludge } \\
\text { centrifuged REDOX } \\
\text { solids. }\end{array}$ & $\begin{array}{l}\text { From HNF-7437. Study performed analysis of solids using ICP technique. Major constituent } \\
\text { mineral type is consistent with waste type as aluminum concentration is 0.036 g-Al/g-solids from } \\
\text { TWINS inventory database. }\end{array}$ \\
\hline Cr-O & SY-102 & $\begin{array}{l}\text { Solids waste type, } \\
\text { although not specified, is } \\
\text { likely NA sludge } \\
\text { centrifuged REDOX } \\
\text { solids. }\end{array}$ & $\begin{array}{l}\text { From HNF-7437. Study performed analysis of solids using ICP technique. Major constituent } \\
\text { TWINS inventory database. }\end{array}$ \\
\hline Fe-O & SY-102 & $\begin{array}{l}\text { Solids waste type, } \\
\text { although not specified, is } \\
\text { likely NA sludge } \\
\text { centrifuged REDOX } \\
\text { solids. }\end{array}$ & $\begin{array}{l}\text { From HNF-7437. Study performed analysis of solids using ICP technique. Major constituent } \\
\text { mineral type is consistent with waste type as iron concentration is } 0.004 \text { g-Fe/g-solids from TWINS } \\
\text { inventory database. }\end{array}$ \\
\hline
\end{tabular}




\subsection{REFERENCES}

\section{Articles:}

Buck, E. C., B. W. Arey, S. K. Fiskum, J. G. H. Geeting, E. D. Jenson, B. K. McNamara, and A. P. Poloski, June 2003, Identification of Washed Solids from Hanford Tanks 241-AN-102 and 241-AZ-101 with X-Ray Diffraction, Scanning Electron Microscopy, and LightScattering Particle Analysis, PNWD-3300 [WTP-RPT-076 Rev. 0], Pacific Northwest National Laboratory, Richland, WA.

Deutsch, W. J., K. J. Cantrell, K. M. Krupka, C. F. Brown, M. J. Lindberg, and H. T. Schaef, October 2004, Hanford Tanks 241-C-203 and 241-C-204: Residual Waste Contaminant Release Model and Supporting Data, PNNL-14903 Rev.1, Pacific Northwest National Laboratory, Richland, WA.

Fiskum, S. K., C. Z. Soderquist, O. T. Farmer, M. J. Steele, L. R. Greenwood, R. G. Swoboda, E. D. Jenson, M. W. Urie, B. M. Oliver, J. J. Wagner, and R. L. Russell, January 2003 , Hanford Tank 241-AZ-102 Waste Concentration and Composition, WTP-RPT-054, Rev 0, Pacific Northwest National Laboratory, Richland, WA.

Johnson GD, NW Kirch, RE Bauer, JM Conner, CW Stewart, BE Wells, and JM Grigsby. 2000. Evaluation of Hanford High-Level Waste Tank 241-SY-101. RPP-6517 Rev. 0, CH2M HILL Hanford Group, Inc., Richland, WA.

Krupka, K. M., N. J. Hess, W. J. Deutsch, H. T. Schaef, M. J. Lindberg, B. W. Arey, and K. J. Cantrell, May, 2004, Hanford Tanks 241-AY-102 and 241-BX-101: Sludge Composition and Contaminant Release Data, PNNL-14614, Pacific Northwest National Laboratory, Richland, WA.

Krupka, K.J., W. J. Deutsch, H T, Schaef, B. W. Arey, S.M. Heald, M. J. Lindberg, and K.J. Cantrell. 2007. Characterization of Solids in Residual Wastes from Underground Storage Tanks at the Hanford Site, Washington, U.S.A. Mater. Res. Soc. Symp. Proc., Vol . 985.

Lindsay, W.L., P.L.G. Vlek, and S.H. Chen. 1989. Phosphate Minerals. In: J.B. Dixon and S.B. Weeds (editors) Minerals in Soil Environments, $2^{\text {nd }}$ Edition. Soil Science Society of America, Madison, WI.

\section{Reports:}

7S110-DLH-03-007, Herting D.L., Cooke, G.A. and Warrant, R.W. to Carothers K.G., October 17, 2003. Caustic Demand Test Results Tank 241AY102 Sludge, CH2MHill.

7S110-DBB-03-013, Bechtold, D.B. and Cooke, G.A. to Horner, T.M., 12-08-2003. Tank 241AP104 Liquid Composite Reboildown Study for Evaporator Campaign 04-02, CH2MHill.

7S110-WSC-03-012, W. S. Callaway to K. G. Carothers, December 12, 2003, Particle Size Distribution Analysis of Samples from Tank 241-AZ-102, Core 310, CH2M HILL Hanford Group, Inc., Richland, Washington. 
7S110-DLH-04-015, Herting D.L. and Cooke, G.A., to Carothers K.G., May 5, 2004. Caustic Demand Test Results Tank 241-C-103 Sludge, CH2MHill Hanford Group Inc., Richland, Washington

7S110-RWW-04-029, Warrant R.W., Cooke G. A., to Rasmussen J. H. October 14, 2004 , 241AP101 \& 241AY102 Mixing Study Report, CH2M Hill.

7S110-DLH-05-028, Herting, D. L., July 28, 2005, Tank 241-AN-102 Process Chemistry Test Results, CH2MHill.

7S110-GAC-06-064, G. A. Cooke, Herting, D. L. and Warrant, R. W., April 5, 2006, Phase Analysis of Tank 241-AP-108 Evaporator Product Solids Using Polarized Light Microscopy \& X-Ray Diffraction \& Scanning Electron Microscopy, CH2MHill.

7S110-WSC-05-011, Callaway, W. S., Cooke, G. A. and Herting, D. L. to K. G. Carothers, March 18, Particle Size Measurements in Support of the Tank 241AN102 Chemistry Control Recovery Plan, CH2MHill.

7S110-JMF-05-015, Frye, J. M., April 29, 2005, Results of Caustic Testing of Tank 241-C-101 \& 241-C-107, CH2MHill.

7S110-DLH-05-040, Herting, D. L., September 15, 2005, Tank AY-102 Centrifuged Solids Analysis Results, CH2MHill.

7S110-DLH-05-041, Herting, D. L., September 29, 2005, Tank SY-102 Analysis Results, Grab Sample 2SY-05-09, CH2MHill.

7S110-DLH-06-049, Herting, D. L., January 5, 2006, Carbonation Test Results Tank 241-AN107, CH2MHill.

7S110-GAC-06-058, 2006, G.A. Cooke, Phase Analysis of Tank 241-AP-108 Grab Sampling Using Polarized Light Microscopy and X-Ray Diffraction Analysis, March 27, CH2M HILL, Hanford Group, Inc. Richland, WA.

7S110-DLH-06-068, D. L. Herting to K. G. Carothers, April 26, 2006, Tank 241-SY-102 Cooling Test Results, CH2MHill, Richland, WA.

7S110-DLH-06-073, Herting, D. L., July 11, 2006, Composition of Solids in Saltcake Residues, CH2MHill.

7S110-RWW-06-080, Warrant, R. W., November, 2006, Results of Caustic Testing of Tank 241AY-102 Core 319 Sludge Solids, CH2M Hill Hanford, Inc.

7S110-WSC-07-143, W. S. Callaway to J. M. Conner, December 31, 2007, Final Results of Boildown Study on Supernatant Liquid Retrieved from Tank 241-AP-105 in June, 3007, CH2MHill, Richland, WA.

7S110-WSC-08-145, W. S. Callaway to J. M. Conner, February 4, 2008, Final Results of Boildown Study on Supernatant Liquid Retrieved from Tank 241-AP-101 in August, 2007, CH2MHill, Richland, WA.

7S110-GAC-08-150, G. A. Cooke, February 27, 2008, Tank 241-AW-106 Core 323, Segment 10 Solids Analysis, CH2M Hill, Richland, WA.

7S110-RWW-08-147, R. W. Warrant to K. G. Carothers, March 4, 2008, Results of Caustic Testing of Tank 241-AY-101 Core 325 Sludge Solids, CH2MHill, Richland, WA. 
74A10-WSC-08-152, W. S. Callaway, G. A. Cooke and D. L. Herting, June 18, 2008, Results of Testiing Performed to Characterize Tank 241-S-112 Heel Solids, CH2M Hill, Richland, WA.

74A10-GAC-08-164, G. A. Cooke to K. G. Carothers, September 29, 2008, Phase Characterization of Solid Samples from Tank 241-AP-108, Core 330. CH2MHill, Richland, WA.

CH2M-0400924, Herting, D.L. and Cooke, G.A to Felmy, A.R., 6 April 2004. Characterization of Yellow Sample from Tank 241S112, CH2M Hill Hanford group Inc., Richland, WA.

CH2M-0400872, Abel, K.H., Distribution of Plutonium-Rich Particles in Tank 241-SY-102 Sludge, 17 May 2004, CH2M Hill.

HNF-7031 Rev.0, D.L. Herting, Saltcake Dissolution FY 2000 Status Report, 9 September 2000, Fluor Hanford Inc., Richland, Washington

HNF-5193 Rev.0, D.L. Herting, Saltcake Dissolution FY 1999 Status Report, 30 September 1999, Numatec Hanford Corp., Richland, Washington

FH-02-02771. 2002. Solid-Phase Characterization of Tank 241-S-112 Dissolution Residues. Letter from G.A. Cooke to J.N. Appel. Fluor Hanford, Richland Washington.

LAB-RPT-10-00001 Rev.0, W.S. Callaway, H.J. Huber, Results of Physicochemical Characterization and Caustic Dissolution Tests on Tank 241-C-108 Heel Solids, Washington River Protection Solutions LLC, June 2010.

RPP-8847 Rev.1B, D.E. Place, B.A. Higley, Best-Basis Inventory Template Compositions of Common Tank Waste Layers, January 2007, CH2M Hill. [Template data were not used. The tank-specific BBI data, used to construct template data, was used instead.]

WRPS-1000562 Rev.0, R.W. Warrant, Results of Caustic Demand Testing of Centrifuged Solids from Tank 241-AN-106 Grab Samples to Address Recovery Plan TF-RP-09-01, Washington River Protection Solutions, 29 April 2010.

WRPS-1000739 Rev.0, R.W. Warrant, Results for the Caustic Demand of Grab Samples from Tank 241-AN-106 to Address Recovery Plan TF-RP-09-01, Washington River Protection Solutions, 29 April 2010. 